\title{
Tackling Solubility Issues in Organic Synthesis: Solid-State Cross- Coupling of Insoluble Aryl Halides
}

Tamae Seo ${ }^{\dagger}$, Naoki Toyoshima ${ }^{\dagger}$, Koji Kubota ${ }^{*+,}$ and Hajime Ito* ${ }^{*+*}$

${ }^{\dagger}$ Division of Applied Chemistry, Graduate School of Engineering, Hokkaido University, Sapporo, Hokkaido, 060-8628, Japan.

¥Institute for Chemical Reaction Design and Discovery (WPI-ICReDD), Hokkaido University, Sapporo, Hokkaido 060-8628, Japan.

e-mail: hajito@eng.hokudai.ac.jp, kbt@eng.hokudai.ac.jp

Table of Contents

1. Chemicals and Instrumentation

2. General Procedure for Solid-State Cross-Coupling

3. General Procedure for Cross-Coupling Reactions in Solution

4. List of Arylboronic Acids and Arylboronic Esters Used in This Study

5. Details of Kinetic Studies

6. Results of Optimization Study

7. Thermography Observation for Reaction Temperature

8. Solubility Evaluation of Starting Materials

9. Differential Scanning Calorimetry Analysis

10. Optical Measurements

11. Single Crystal $X$-ray Structure Analyses

12. Characterization of Coupling Products

13. References

14. NMR Spectra 


\section{Chemicals and Instrumentation.}

The starting materials were obtained from commercial suppliers and used as received. Solvents were

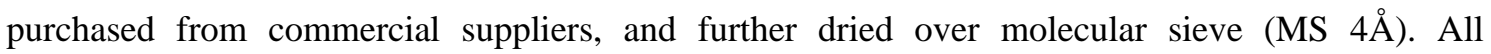
mechanochemical reactions were carried out using grinding vessels in a Retsch MM400 mill (Figure S1). Both jars (1.5 mL) and balls (5 mm) are made of stainless (SUS400B and SUS420J2, respectively) (Figure S2). The heat gun Takagi HG-1450B with temperature control function was used for hightemperature ball-milling reactions (Figure S3). NMR spectra were recorded on JEOL JNM-EC X400P and JNM-ECS400 spectrometers $\left({ }^{1} \mathrm{H}\right.$ : 392 or 396 or 399 or $401 \mathrm{MHz},{ }^{13} \mathrm{C}$ : 99 or $100 \mathrm{MHz}$ ). Tetramethylsilane $\left({ }^{1} \mathrm{H}\right), \mathrm{CDCl}_{3}\left({ }^{13} \mathrm{C}\right)$ was employed as external standards, respectively. Multiplicity was recorded as follows: $\mathrm{s}=$ singlet, brs $=$ broad singlet, $\mathrm{d}=$ doublet, $\mathrm{t}=$ triplet, $\mathrm{q}=$ quartet, quint $=$ quintet, sept $=$ septet, $\mathrm{o}=$ octet, $\mathrm{m}=$ multiplet. 1,1,2,2-Tetrachloroethane was used as an internal standard to determine NMR yields. Recycle preparative gel permeation chromatography (GPC) was conducted with a JAI LC-9101 using $\mathrm{CHCl}_{3}$ as an eluent with JAIGEL-1H. GLC analyses were conducted with a Shimadzu GC-2014 or GC-2025 equipped with ULBON HR-1 glass capillary column (Shinwa Chemical Industries) or SH-Rtx-5MS glass capillary column (Shimadzu Corporation) and an FID detector. Thermography was recorded with an NEC Avio Thermo GEAR G120. DSC analyses were performed on Seiko EXSTAR (DSC7200) under a nitrogen atmosphere. Single crystal X-ray structural analyses were carried out on a Rigaku XtaLAB PRO MM007 diffractometer using graphite monochromated Mo-K $\mathrm{K}_{\mathrm{a}}$ radiation and PILATUS-200K detector. The structure was solved by direct methods and expanded using Fourier techniques. Non-hydrogen atoms were refined anisotropically. Hydrogen atoms were refined using the riding model. All calculations were performed using the Olex 2 crystallographic software package except for refinement, which was performed using SHELXL-2018. ${ }^{1}$ Emission spectra were recorded on a Hitachi F-7000 spectrometer. Absorption spectra were recorded on a Hitachi U-2910 spectrometer. The emission quantum yields were recorded on a Hamamatsu Quantaurus-QY spectrometer with an integrating sphere. High-resolution mass spectra were recorded at the Global Facility Center, Hokkaido University. Powder diffraction data were recorded on a Rigaku SmartLab diffractometer with $\mathrm{Cu}-\mathrm{K}_{\alpha}$ radiation and $\mathrm{D} / \mathrm{teX}$ Ultra detector covering $5-60^{\circ}(2 \theta)$. 


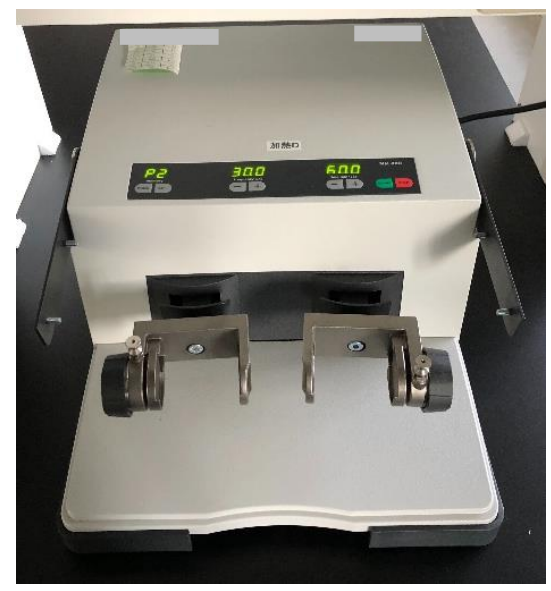

Figure S1. Retsch MM400 used in this study.

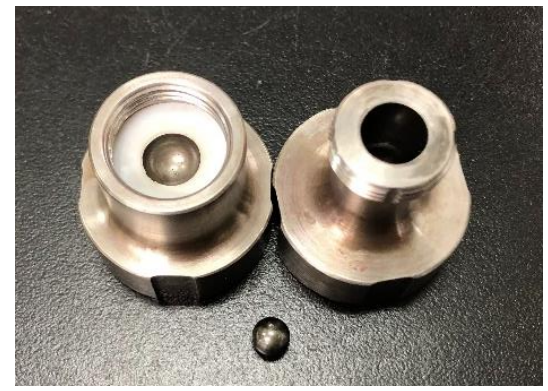

Figure S2. Stainless jar and ball used in this study.

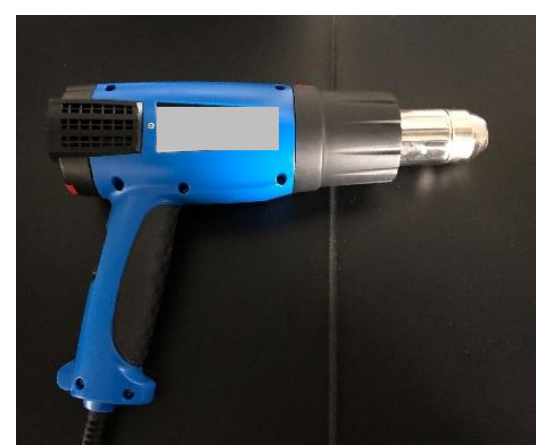

Figure S3. The temperature controllable heat gun Takagi HG-1450B used in this study. 


\section{General Procedure for Solid-State Cross-Coupling.}

1) Procedure A: Solid-state cross-coupling reactions for Class 1

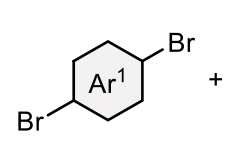

1

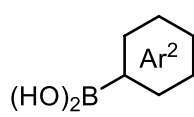

2

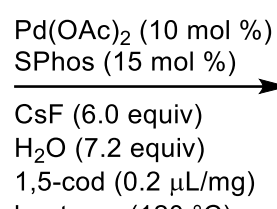

$1,5-\operatorname{cod}(0.2 \mu \mathrm{L} / \mathrm{mg})$ heat gun $\left(120^{\circ} \mathrm{C}\right)$ milling $(30 \mathrm{~Hz})$

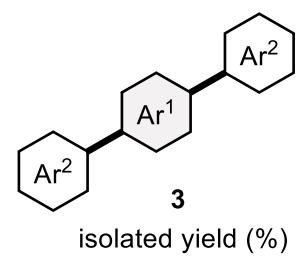

Aryl halide 1 ( $0.15 \mathrm{mmol})$, aryl boronic acid 2 (0.36 mmol, 2.4 equiv), $\mathrm{Pd}(\mathrm{OAc})_{2}(0.015 \mathrm{mmol}, 10$ mol \%) and SPhos ( $0.023 \mathrm{mmol}, 15 \mathrm{~mol} \%), \mathrm{CsF}(0.9 \mathrm{mmol}, 6.0$ equiv) were placed in a ball milling vessel (stainless, $1.5 \mathrm{~mL}$ ) loaded with one grinding ball (stainless, diameter: $5 \mathrm{~mm}$ ). Then $\mathrm{H}_{2} \mathrm{O}(20 \mu \mathrm{L}$, 7.2 equiv) and 1,5-cod $(0.2 \mu \mathrm{L} / \mathrm{mg})$ were added via syringe. After the vessel was closed in air without purging with inert gas, the vessel was placed in the ball mill (Retsch MM400, 5 min or 60 min at 30 $\mathrm{Hz}$ ) and a heat gun (the preset temperature at $250^{\circ} \mathrm{C}$ ). After $5 \mathrm{~min}$ or $60 \mathrm{~min}$, the jar was then cooled rapidly with cold water and opened. The mixture was filtration with $\mathrm{CH}_{2} \mathrm{Cl}_{2}$ to remove the starting material and inorganic salts. The mixture was extracted with $\mathrm{CH}_{2} \mathrm{Cl}_{2}$ three times. The crude mixture was then purified by flash column chromatography $\left(\mathrm{SiO}_{2}\right.$, typically $\mathrm{CH}_{2} \mathrm{Cl}_{2} /$ hexane, typically 0-50:50) or reprecipitation from $\mathrm{CH}_{2} \mathrm{Cl}_{2} / \mathrm{MeOH}$ to give the corresponding coupling product 3 .

\section{2) Procedure B: Solid-state cross-coupling reactions for Class 2 and Class 3}

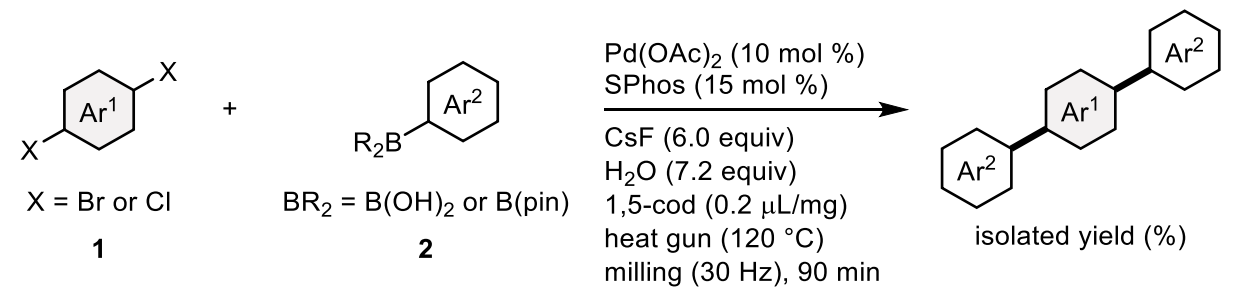

Aryl halide 1 ( $0.15 \mathrm{mmol})$, aryl boronic acid 2 ( $0.36 \mathrm{mmol}, 2.4$ equiv), $\mathrm{Pd}(\mathrm{OAc})_{2}(0.015 \mathrm{mmol}, 10$ mol \%) and SPhos ( $0.023 \mathrm{mmol}, 15 \mathrm{~mol} \%), \mathrm{CsF}(0.9 \mathrm{mmol}, 6.0$ equiv) were placed in a ball milling vessel (stainless, $1.5 \mathrm{~mL}$ ) loaded with one grinding ball (stainless, diameter: $5 \mathrm{~mm}$ ). Then $\mathrm{H}_{2} \mathrm{O}(20 \mu \mathrm{L}$, 7.2 equiv) and 1,5-cod $(0.2 \mu \mathrm{L} / \mathrm{mg})$ were added via syringe. After the vessel was closed in air without purging with inert gas, the vessel was placed in the ball mill (Retsch MM400, $90 \mathrm{~min}$ at $30 \mathrm{~Hz}$ ) and a heat gun (the preset temperature at $250^{\circ} \mathrm{C}$ ). After $90 \mathrm{~min}$, the jar was then cooled rapidly with cold water and opened. The starting materials 1 that belong to Class 2 and Class 3 hardly dissolve in $\mathrm{CH}_{2} \mathrm{Cl}_{2}$, while the arylated products $\mathbf{3}$ exhibit much better solubility toward $\mathrm{CH}_{2} \mathrm{Cl}_{2}$. Thus, the product $\mathbf{3}$ was dissolved in $\mathrm{CH}_{2} \mathrm{Cl}_{2}$, and the starting materials $\mathbf{1}$ as well as other inorganic salts were removed by filtration with $\mathrm{CH}_{2} \mathrm{Cl}_{2}$ (typically $1.5 \mathrm{~L}$ of $\mathrm{CH}_{2} \mathrm{Cl}_{2}$ was used). The filtrate was then concentrated under reduced pressure and the thus obtained crude residue was then purified by flash column 
chromatography ( $\mathrm{SiO}_{2}$, typically $\mathrm{CH}_{2} \mathrm{Cl}_{2}$ /hexane, typically 0-50:50) to give the corresponding coupling product $\mathbf{3}$.

The heat gun was fixed with clamps and placed directly above the ball milling jar (distance between the heat gun and ball milling jar: ca. $1 \mathrm{~cm}$ ) (Figure S4). The set-up procedure for high-temperature ball-milling reactions was shown in Figure S5. First, one grinding ball (stainless, diameter: $5 \mathrm{~mm}$ ) was loaded in a ball milling jar (stainless, $1.5 \mathrm{~mL}$ ). Then solid and liquid materials were added to the jar. After the ball milling jar was closed, the jar was placed in the ball mill (Retsch MM400) and a heat gun was placed directly above the ball-milling jar. The mechanochemical cross-coupling reactions were conducted while applying heated air to the outside of the milling jar (the preset temperature at $\left.250{ }^{\circ} \mathrm{C}\right)$.
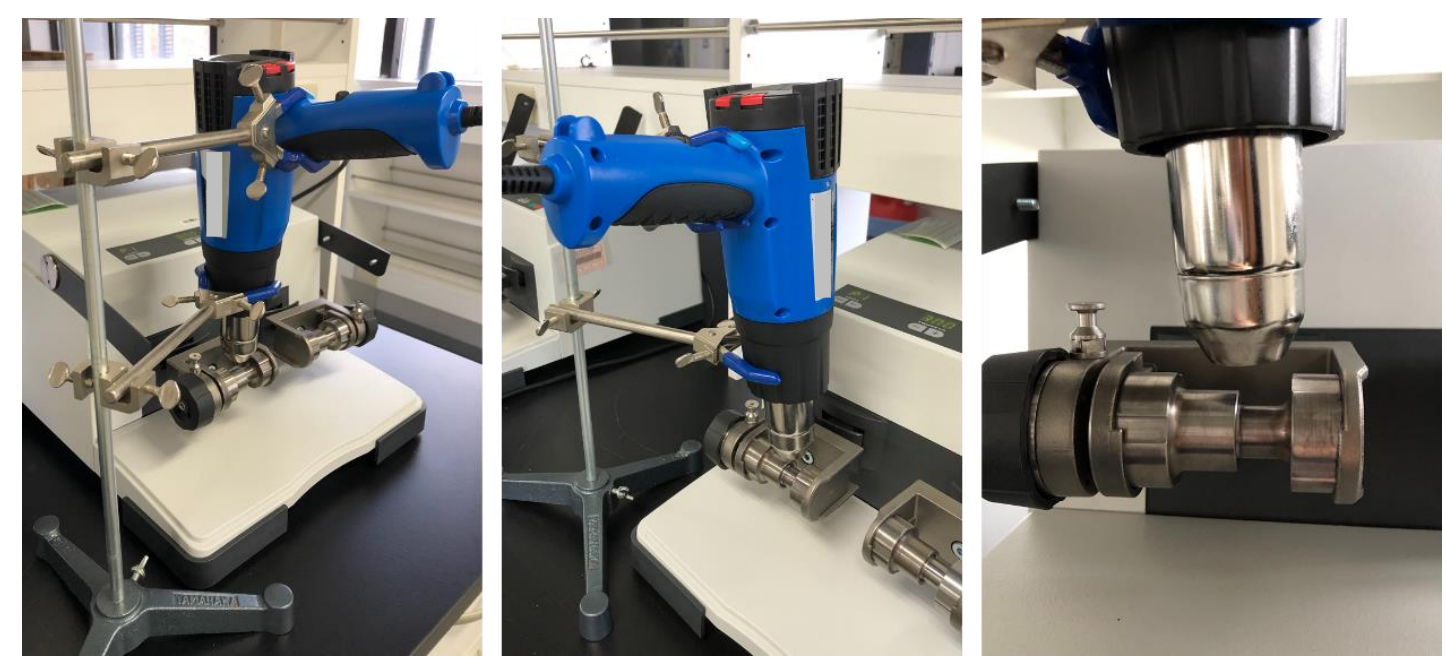

Figure S4. The set-up procedure for a heat gun on MM400. 

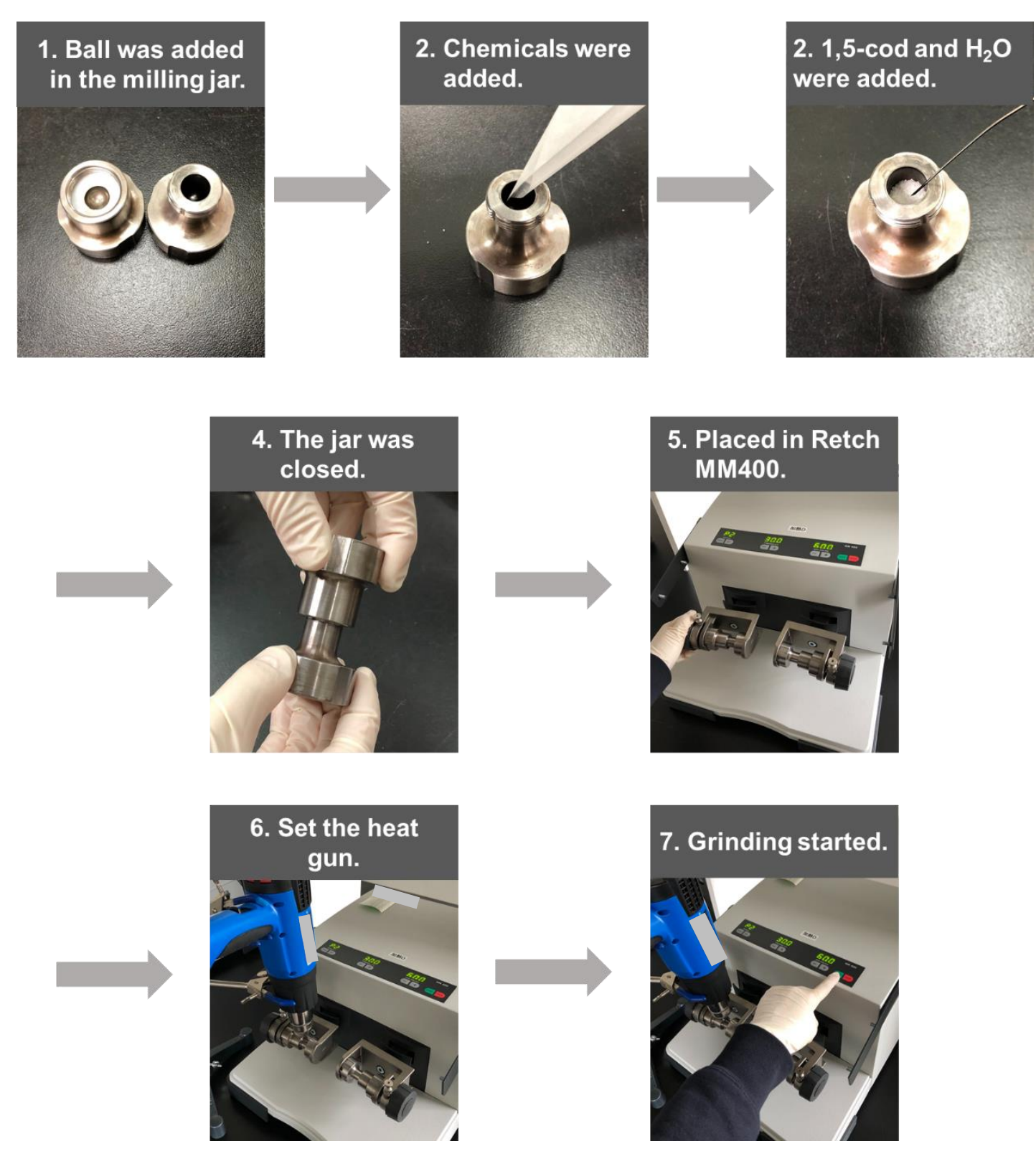

Figure S5. The set-up procedure for the high-temperature ball-milling solid-state cross-coupling. 


\section{General Procedure for Cross-Coupling Reactions in Solution.}

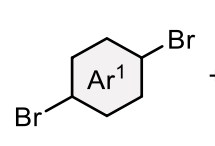

1

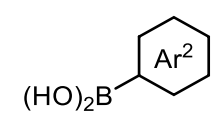

2

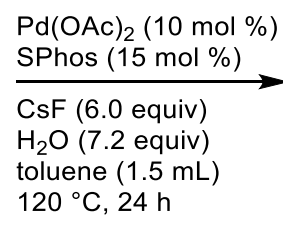

$\mathrm{Pd}(\mathrm{OAc})_{2}(10 \mathrm{~mol} \%)$

CsF (6.0 equiv)

$\mathrm{H}_{2} \mathrm{O}$ (7.2 equiv)

$120^{\circ} \mathrm{C}, 24 \mathrm{~h}$

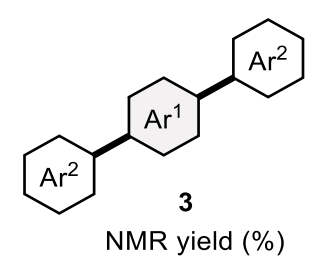

NMR yield (\%)

Aryl halide 1 ( $0.15 \mathrm{mmol})$, aryl boronic acid 2 ( $0.36 \mathrm{mmol}, 2.4$ equiv), $\mathrm{Pd}(\mathrm{OAc})_{2}(0.015 \mathrm{mmol}, 10$ mol \%) and SPhos ( $0.023 \mathrm{mmol}, 15 \mathrm{~mol} \%), \mathrm{CsF}(0.9 \mathrm{mmol}, 6.0$ equiv) were placed in an oven-dried reaction vial. After the vial was sealed with a screw cap containing a Teflon-coated rubber septum, the vial was connected to a vacuum/nitrogen manifold through a needle. It was evacuated and then backfilled with nitrogen. This cycle was repeated three times. After toluene $(1.5 \mathrm{~mL})$ was added into the vial through the rubber septum. Then $\mathrm{H}_{2} \mathrm{O}\left(20 \mu \mathrm{L}, 7.2\right.$ equiv) was added to the mixture at $120{ }^{\circ} \mathrm{C}$ using an oil bath. After 24 hours, the mixture was extracted with $\mathrm{CH}_{2} \mathrm{Cl}_{2}$ three times or filtration with $\mathrm{CH}_{2} \mathrm{Cl}_{2}$. ${ }^{1} \mathrm{H}$ NMR analysis of the resulting crude mixture was measured to determine the yield of products. 
4. List of Arylboronic Acids and Arylboronic Esters Used in This Study.<smiles>COc1ccc([18OH])cc1</smiles>

$2 a$

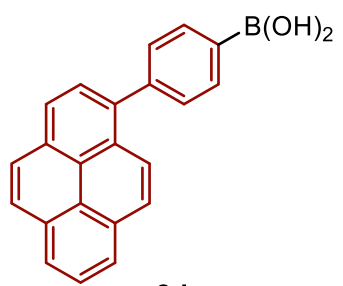

2o

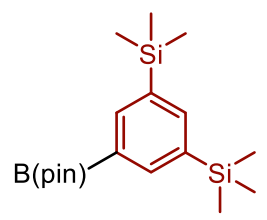

$2 \mathrm{~g}$<smiles>Oc1cccc2ccccc12</smiles>

$2 b$

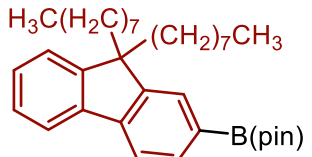

$2 e$

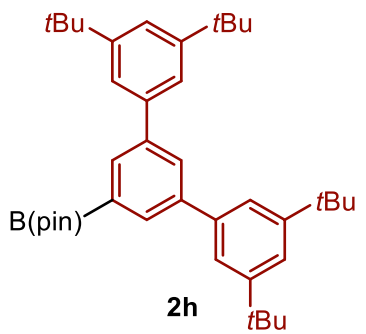<smiles>Oc1ccc(N(c2ccccc2)c2ccccc2)cc1</smiles>

2c

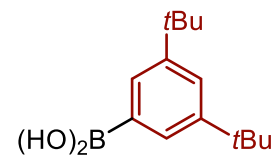

$2 f$<smiles>CCCCC(CC)Cc1csc(Br)c1</smiles>

Figure S6. List of arylboronic acids and aryl boronic esters used in this study. 


\section{Details of Kinetic Studies}

Reactions were conducted in a Retsch MM400 ball mill in a stainless-steel milling jar (1.5 mL) at $30 \mathrm{~Hz}$ using one stainless-steel ball (diameter: $5 \mathrm{~mm}$ ) (Scheme S1 and Figure S7). As a periodic sampling of the mechanochemical reaction runs requires stopping the mill and opening the jar, each data point was obtained from an individual reaction. Yields were determined by ${ }^{1} \mathrm{H}$ NMR analysis with an internal standard.<smiles>Brc1ccc(-c2c(-c3ccccc3)c(-c3ccccc3)c(-c3ccccc3)c(-c3ccccc3)c2-c2ccccc2)cc1</smiles>

$0.15 \mathrm{mmo}$

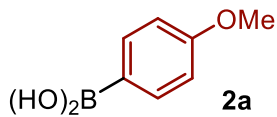

(2.4 equiv)

$\mathrm{Pd}(\mathrm{OAc})_{2}(10 \mathrm{~mol} \%)$ SPhos $(15 \mathrm{~mol} \%)$ CsF (6.0 equiv)

$\mathrm{H}_{2} \mathrm{O}$ (7.2 equiv) $1,5-\operatorname{cod}(0.2 \mu \mathrm{L} / \mathrm{mg})$ milling $(30 \mathrm{~Hz})$ with or without heating $\mathrm{MeO}$<smiles>COc1ccc(-c2ccc(-c3c(-c4ccccc4)c(-c4ccccc4)c(-c4ccccc4)c(-c4ccccc4)c3-c3ccccc3)cc2)cc1</smiles>
3a

NMR yield (\%)

Ball milling with heating

Ball milling without heating

\begin{tabular}{cccccc}
\hline time $(\min )$ & 0 & 5 & 15 & 30 & 60 \\
\hline NMR yield $(\%)$ & 0 & $>99$ & $>99$ & $>99$ & $>99$ \\
\hline
\end{tabular}

\begin{tabular}{cccccc}
\hline time $(\min )$ & 0 & 5 & 15 & 30 & 60 \\
\hline NMR yield $(\%)$ & 0 & n.r. & n.r. & n.r. & n.r. \\
\hline
\end{tabular}<smiles>Brc1ccc(-c2c(-c3ccccc3)c(-c3ccccc3)c(-c3ccccc3)c(-c3ccccc3)c2-c2ccc(Br)cc2)cc1</smiles>

$1 \mathrm{a}$

$0.15 \mathrm{mmol}$<smiles>COc1ccc([18OH])cc1</smiles>

(2.4 equiv)

$\mathrm{Pd}(\mathrm{OAc})_{2}(10 \mathrm{~mol} \%)$ SPhos (15 mol \%) CsF (6.0 equiv)

$\mathrm{H}_{2} \mathrm{O}$ (7.2 equiv) toluene $(1.5 \mathrm{~mL})$ $120^{\circ} \mathrm{C}$

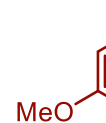

$\mathrm{MeO}$<smiles>COc1ccc(-c2ccc(-c3c(-c4ccccc4)c(-c4ccccc4)c(-c4ccccc4)c(-c4ccc(-c5ccc(C)cc5)cc4)c3-c3ccccc3)cc2)cc1</smiles>

\begin{tabular}{cccccc}
\hline time $(\mathrm{h})$ & 0 & 0.5 & 1 & 1.5 & 24 \\
\hline NMR yield $(\%)$ & 0 & 9 & 30 & 51 & 68 \\
\hline
\end{tabular}

Scheme S1. Kinetic studies under ball mill and solution conditions. 
A<smiles>Brc1ccc(-c2c(-c3ccccc3)c(-c3ccccc3)c(-c3ccccc3)c(-c3ccccc3)c2-c2ccccc2)cc1</smiles><smiles>COc1ccc(CO)cc1</smiles>
2a (2.4 equiv) $\mathrm{Pd}(\mathrm{OAc})_{2}(10 \mathrm{~mol} \%)$ SPhos (15 mol \%)

CsF (6.0 equiv) $\mathrm{H}_{2} \mathrm{O}$ (7.2 equiv) $1,5-\operatorname{cod}(0.2 \mu \mathrm{L} / \mathrm{mg})$ $1.5 \mathrm{~mL}$ jar, $5 \mathrm{~mm}$ bal heat-gun milling $(30 \mathrm{~Hz})$, time<smiles>COc1ccc(-c2ccc(-c3c(-c4ccccc4)c(-c4ccccc4)c(-c4ccccc4)c(-c4ccccc4)c3-c3ccccc3)cc2)cc1</smiles>

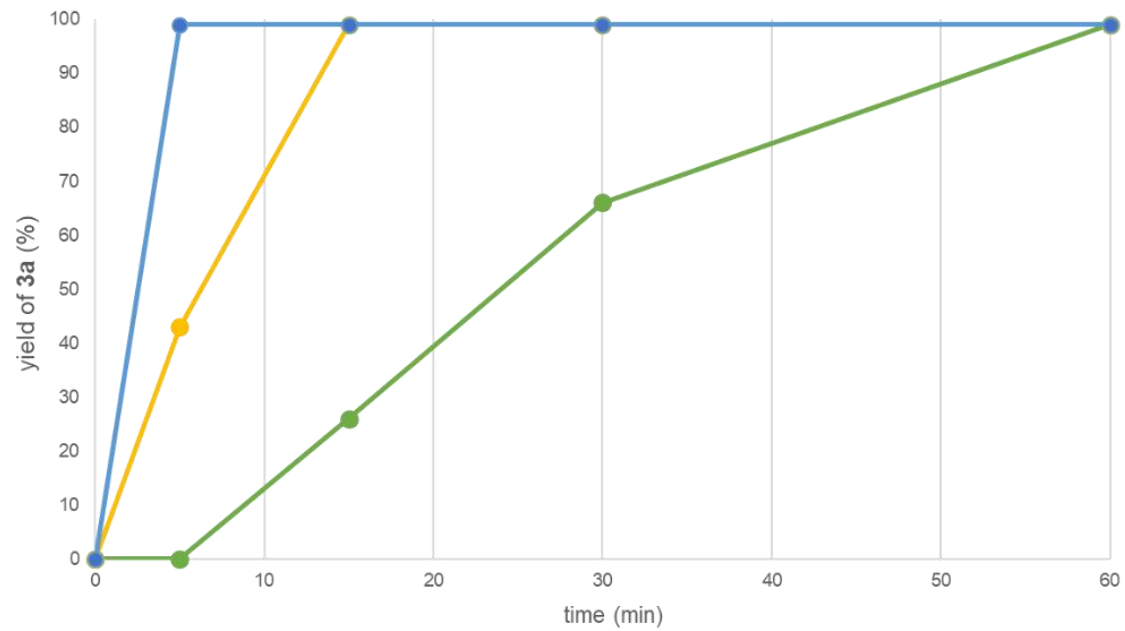

Ball milling with heating $\left(\begin{array}{l}\text { Preset temp.: } 200{ }^{\circ} \mathrm{C} \\ \text { Inside temp.: } 91.1^{\circ} \mathrm{C}\end{array}\right)$

Ball milling with heating $\left(\begin{array}{l}\text { Preset temp.: } 150{ }^{\circ} \mathrm{C} \\ \text { Inside temp.: } 79.4{ }^{\circ} \mathrm{C}\end{array}\right)$

Ball milling with heating $\left(\begin{array}{l}\text { Preset temp.: } 100{ }^{\circ} \mathrm{C} \\ \text { Inside temp.: } 62.2^{\circ} \mathrm{C}\end{array}\right)$

B

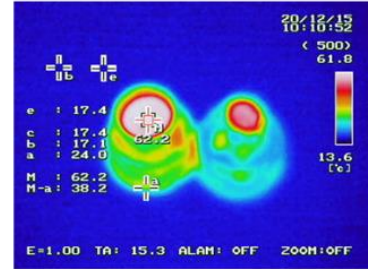

Preset temp.: $100{ }^{\circ} \mathrm{C}$ Inside temp.: $62.2^{\circ} \mathrm{C}$

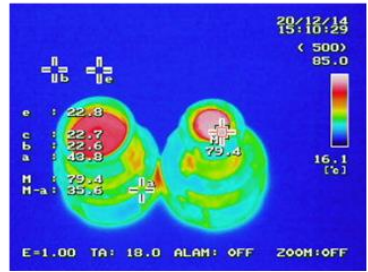

Preset temp.: $150{ }^{\circ} \mathrm{C}$ Inside temp.: $79.4^{\circ} \mathrm{C}$

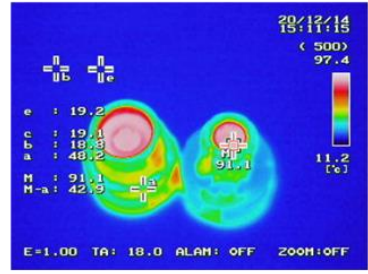

Preset temp.: $200{ }^{\circ} \mathrm{C}$ Inside temp.: $91.1^{\circ} \mathrm{C}$

Figure S7. A, Kinetic studies under the different preset temperatures of a heat gun. B, Thermographic image of the milling jar after the reaction under the high-temperature ball-milling conditions. 


\section{Results of Optimization Study.}

\section{Ligand screening under mechanochemical conditions}

When the reaction was carried out under the $\mathrm{Pd}(\mathrm{OAc})_{2} / \mathrm{DavePhos}$ catalytic system we reported ${ }^{2}$, the product 3a was obtained in high yield (Scheme S2, 96\% NMR yield). When SPhos was used instead of DavePhos as a ligand, the yield was improved (Scheme S2, >99\% NMR yield). When Pigment violet $23(\mathbf{1 k})$ was used as a substrate, the $\mathrm{Pd}(\mathrm{OAc})_{2} / \mathrm{SPhos} / 1,5$-cod catalytic system provided a higher yield than that of the $\mathrm{Pd}(\mathrm{OAc})_{2} / \mathrm{DavePhos} / 1,5$-cod catalytic system.<smiles>Brc1ccc(-c2c(-c3ccccc3)c(-c3ccccc3)c(-c3ccccc3)c(-c3ccccc3)c2-c2ccc(Br)cc2)cc1</smiles>

$1 \mathrm{a}$

$0.15 \mathrm{mmol}$

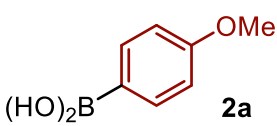

(2.4 equiv)

$\mathrm{Pd}(\mathrm{OAc})_{2}(10 \mathrm{~mol} \%)$ ligand $(15 \mathrm{~mol} \%)$

CsF (6.0 equiv)

$$
\mathrm{H}_{2} \mathrm{O} \text { (7.2 equiv) }
$$

$1,5-\operatorname{cod}(0.2 \mu \mathrm{L} / \mathrm{mg})$

heat gun $\left(120^{\circ} \mathrm{C}\right)$

milling $(30 \mathrm{~Hz}), 5$ min

$\mathrm{MeO}$

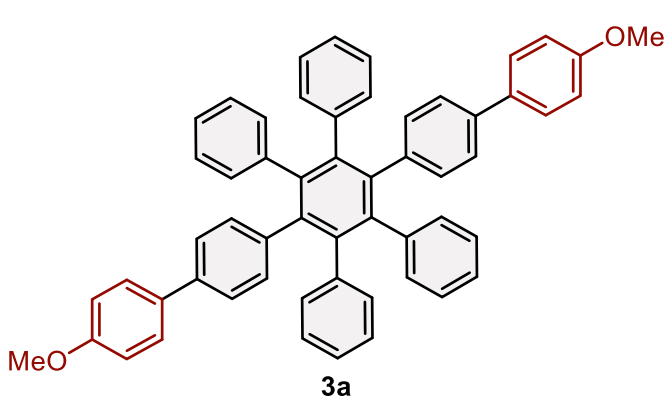

$\mathrm{Pd}(\mathrm{OAc})_{2} /$ DavePhos : $96 \%$ (NMR)
$\mathrm{Pd}(\mathrm{OAc})_{2} /$ SPhos : $>99 \%$ (NMR)<smiles></smiles>

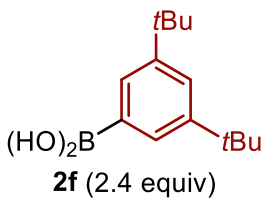

$\mathrm{Pd}(\mathrm{OAc})_{2}(10 \mathrm{~mol} \%)$ ligand $(15 \mathrm{~mol} \%)$ CsF (6.0 equiv)

$\mathrm{H}_{2} \mathrm{O}$ (7.2 equiv) $1,5-\operatorname{cod}(0.2 \mu \mathrm{L} / \mathrm{mg})$ heat gun $\left(120^{\circ} \mathrm{C}\right)$ milling $(30 \mathrm{~Hz}), 90 \mathrm{~min}$

$1 \mathrm{k}(0.10 \mathrm{mmol})$

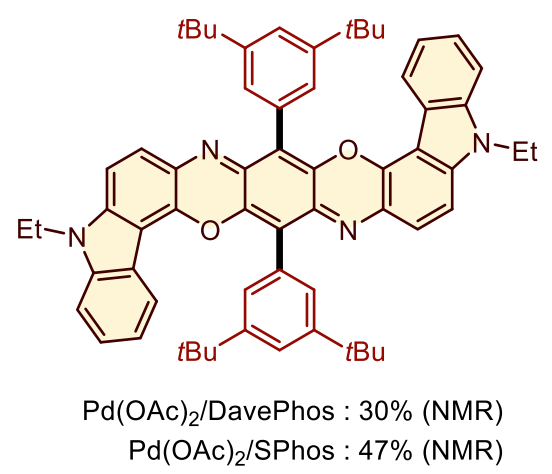

Scheme S2. Ligand screening for $1 \mathbf{a}$ and $1 \mathbf{k}$ under high-temperature ball-milling conditions. 


\section{Catalyst loading under high-temperature ball-milling conditions}

We investigated the amount of catalyst for the mechanochemical coupling reaction between $1 \mathbf{a}$ and 2a (Table S1). Although the catalyst loading was reduced to $\mathrm{Pd}(\mathrm{OAc})$ (3 mol \%) and SPhos (4.5 mol \%), the coupling product was obtained quantitatively within 5 minutes under high-temperature ball-milling conditions.<smiles>Brc1ccc(-c2c(-c3ccccc3)c(-c3ccccc3)c(-c3ccccc3)c(-c3ccccc3)c2-c2ccc(Br)cc2)cc1</smiles>

1a $(0.15 \mathrm{mmol})$<smiles>COc1ccc(O)cc1</smiles>

2a (2.4 equiv) $\mathrm{Pd}(\mathrm{OAc})_{2}(\mathrm{x} \mathrm{mol} \%)$ SPhos (y mol \%)

CsF (6.0 equiv) $\mathrm{H}_{2} \mathrm{O}$ (7.2 equiv) $1,5-\operatorname{cod}(0.2 \mu \mathrm{L} / \mathrm{mg})$ milling $(30 \mathrm{~Hz}), 5 \mathrm{~min}$ heat gun $\left(120^{\circ} \mathrm{C}\right)$<smiles>COc1ccc(-c2ccc(-c3c(-c4ccccc4)c(-c4ccccc4)c(-c4ccccc4)c(-c4ccccc4)c3-c3ccccc3)cc2)cc1</smiles>

3a

\begin{tabular}{ccc}
\hline $\mathrm{x} \mathrm{mol} \%$ & $\mathrm{y} \mathrm{mol} \mathrm{\%}$ & NMR yield $(\%)$ \\
\hline 10 & 15 & $>99$ \\
5 & 7 & $>99$ \\
3 & 4.5 & $>99$ \\
\hline
\end{tabular}

Table S1. Catalyst loading under high-temperature ball-milling conditions. 


\section{Screening of palladium catalysts under solution conditions}

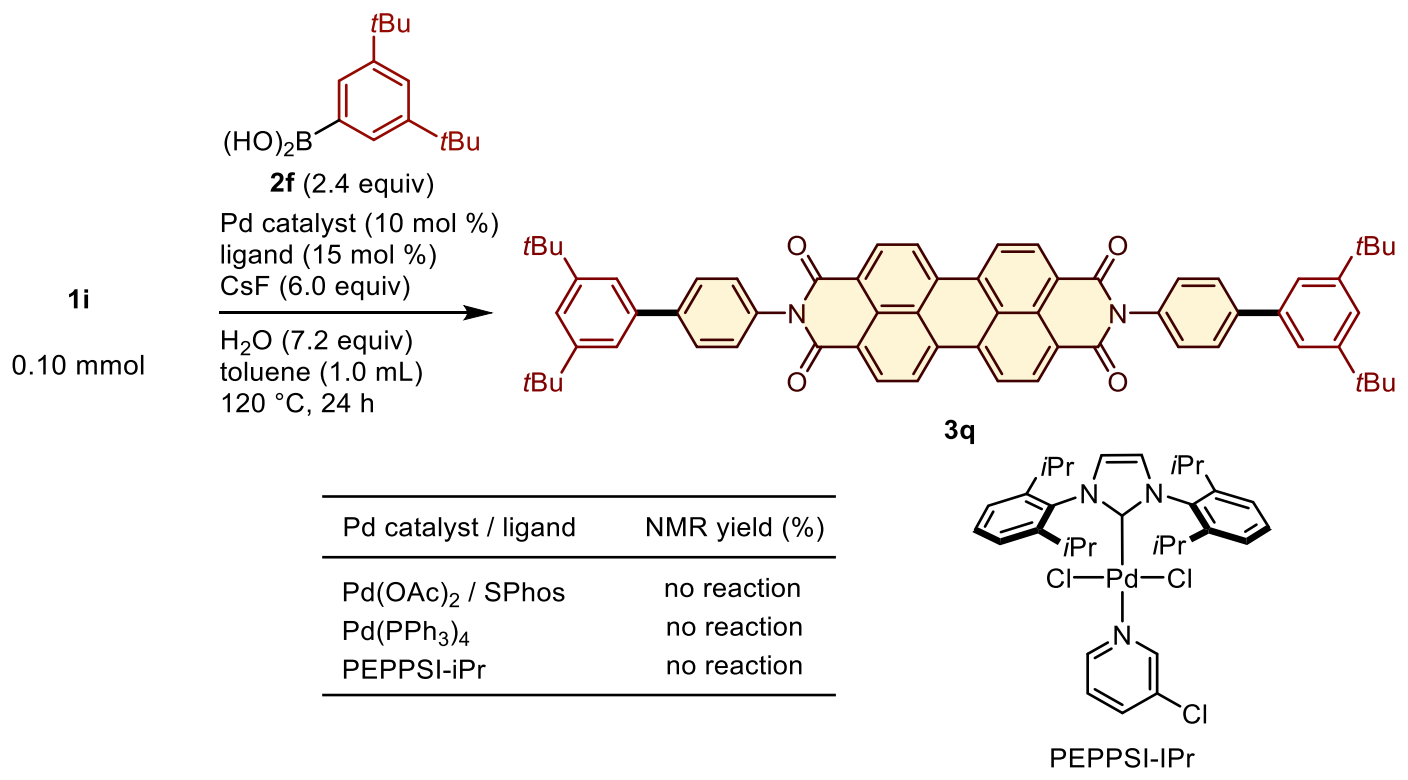

Scheme S3. Screening of palladium catalysts for $1 \mathbf{i}$ under solution conditions.

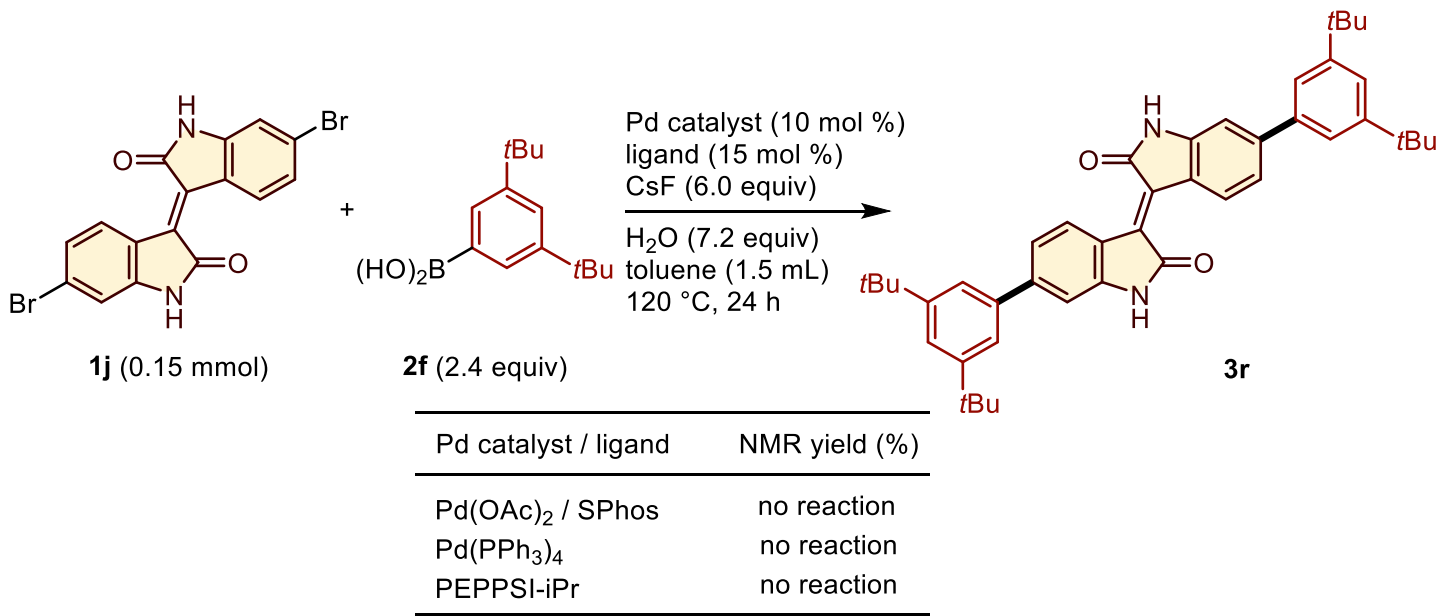

Scheme S4. Screening of palladium catalysts for $\mathbf{1} \mathbf{j}$ under solution conditions. 
<smiles></smiles>

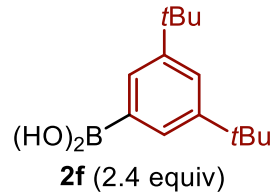

Pd catalyst (10 mol \%) ligand (15 mol \%) CsF (6.0 equiv)

$\mathrm{H}_{2} \mathrm{O}$ (7.2 equiv) toluene $(1.0 \mathrm{~mL})$ $120{ }^{\circ} \mathrm{C}, 24 \mathrm{~h}$

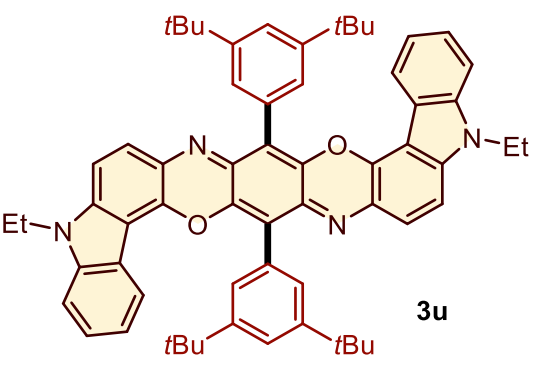

\begin{tabular}{ll}
\hline Pd catalyst / ligand & NMR yield (\%) \\
\hline $\mathrm{Pd}(\mathrm{OAc})_{2} / \mathrm{SPhos}$ & no reaction \\
$\mathrm{Pd}(\mathrm{PPh})_{4}$ & no reaction \\
$\mathrm{PEPPSI}-\mathrm{iPr}$ & no reaction \\
\hline
\end{tabular}

Scheme S5. Screening palladium catalysts for $\mathbf{1 k}$ under solution conditions.

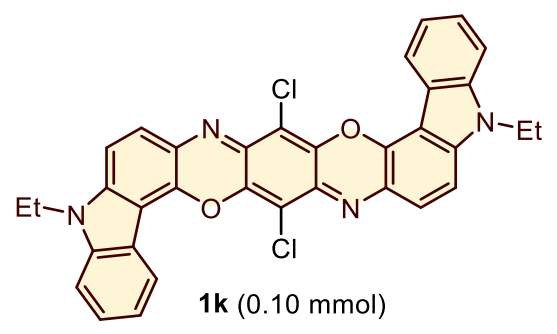<smiles></smiles>

$$
2 f \text { (2.4 equiv) }
$$

$\mathrm{Pd}(\mathrm{OAc})_{2}(10 \mathrm{~mol} \%)$ SPhos $(15 \mathrm{~mol} \%)$ $\mathrm{CsF}$ (6.0 equiv)

$\mathrm{H}_{2} \mathrm{O}$ (7.2 equiv) solvent $(1.0 \mathrm{~mL})$ temp., $24 \mathrm{~h}$<smiles></smiles>

\begin{tabular}{lrc}
\hline solvent & temp. & NMR yield $(\%)$ \\
\hline toluene & $120^{\circ} \mathrm{C}$ & no reaction \\
dioxane & $120^{\circ} \mathrm{C}$ & no reaction \\
THF & $80^{\circ} \mathrm{C}$ & no reaction \\
DMF & $120^{\circ} \mathrm{C}$ & no reaction \\
DMA & $120^{\circ} \mathrm{C}$ & no reaction \\
\hline
\end{tabular}

Scheme S6. Solvent screening for $1 \mathbf{k}$ under solution conditions. 
Impact of solvent amount under solution conditions.

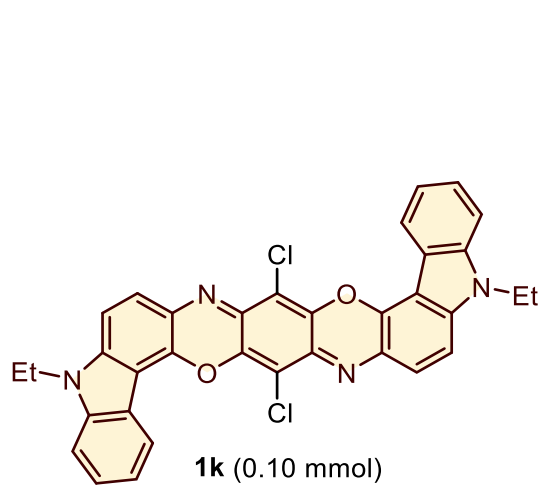<smiles>CC(C)(C)c1cc([18OH])cc(C(C)(C)C)c1</smiles>

$2 \mathbf{f}$ (2.4 equiv)

$\mathrm{Pd}(\mathrm{OAc})_{2}(10 \mathrm{~mol} \%)$

SPhos (15 mol \%)

CsF (6.0 equiv)

$\mathrm{H}_{2} \mathrm{O}$ (7.2 equiv)

toluene $(\mathrm{x} \mathrm{mL})$

$120^{\circ} \mathrm{C}, 24 \mathrm{~h}$

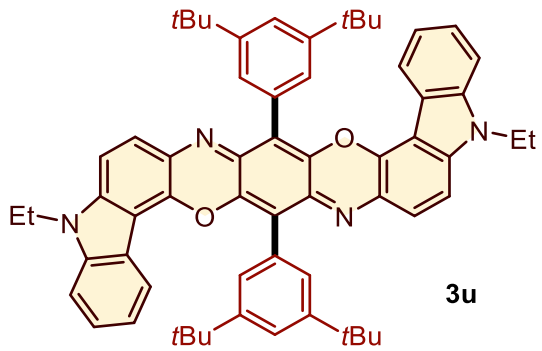

\begin{tabular}{cc}
\hline solvent amount $(\mathrm{mL})$ & NMR yield $(\%)$ \\
\hline 1.0 & no reaction \\
2.0 & no reaction \\
\hline
\end{tabular}

Scheme S7. Impact of amount of under solution conditions.

\section{Screening of palladium catalysts under mechanochemical conditions.}
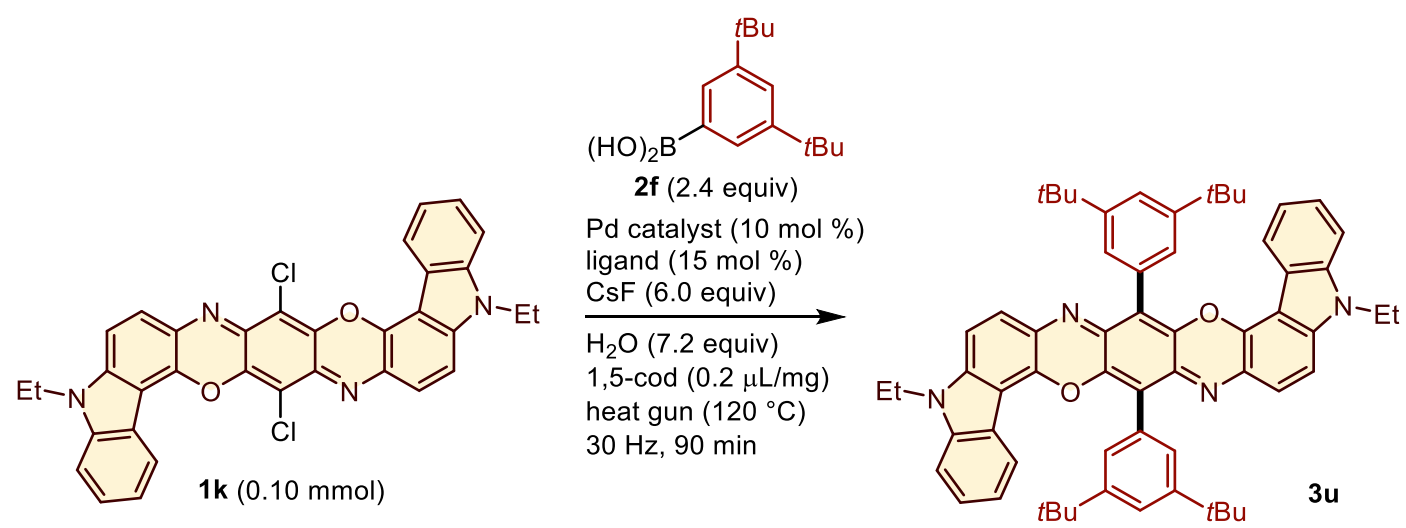

\begin{tabular}{lc}
\hline Pd catalyst / ligand & NMR yield $(\%)$ \\
\hline $\mathrm{Pd}(\mathrm{OAC})_{2} /$ SPhos & $47(30)^{a}$ \\
$\mathrm{Pd}\left(\mathrm{PPh}_{3}\right)_{4}$ & no reaction \\
$\mathrm{PEPPSI}-\mathrm{Pr}$ & no reaction \\
\hline alsolated yield. &
\end{tabular}

Scheme S8. Screening of palladium catalysts for $1 \mathbf{k}$ under high-temperature ball-milling conditions. 
We carried out the reaction under the mechanochemical conditions reported by Felipe and Stuparu (Scheme S9). ${ }^{3}$ When 1a was used as a substrate, the reaction did not proceed well within 60 minutes (7\% NMR yield). In addition, the coupling product $\mathbf{3} \mathbf{u}$ was not obtained when $\mathbf{1 k}$ was used as a substrate under the same conditions.<smiles>Brc1ccc(-c2c(-c3ccccc3)c(-c3ccccc3)c(-c3ccccc3)c(-c3ccccc3)c2-c2ccc(Br)cc2)cc1</smiles>

1a $(0.15 \mathrm{mmol})$<smiles></smiles>

(2.4 equiv)

$\mathrm{Pd}(\mathrm{OAc})_{2}(10 \mathrm{~mol} \%)$ $\mathrm{K}_{2} \mathrm{CO}_{3}$ (10 equiv)

$\mathrm{NaCl}(100 \mathrm{mg})$

heat gun $\left(120^{\circ} \mathrm{C}\right)$

milling $(30 \mathrm{~Hz})$, time
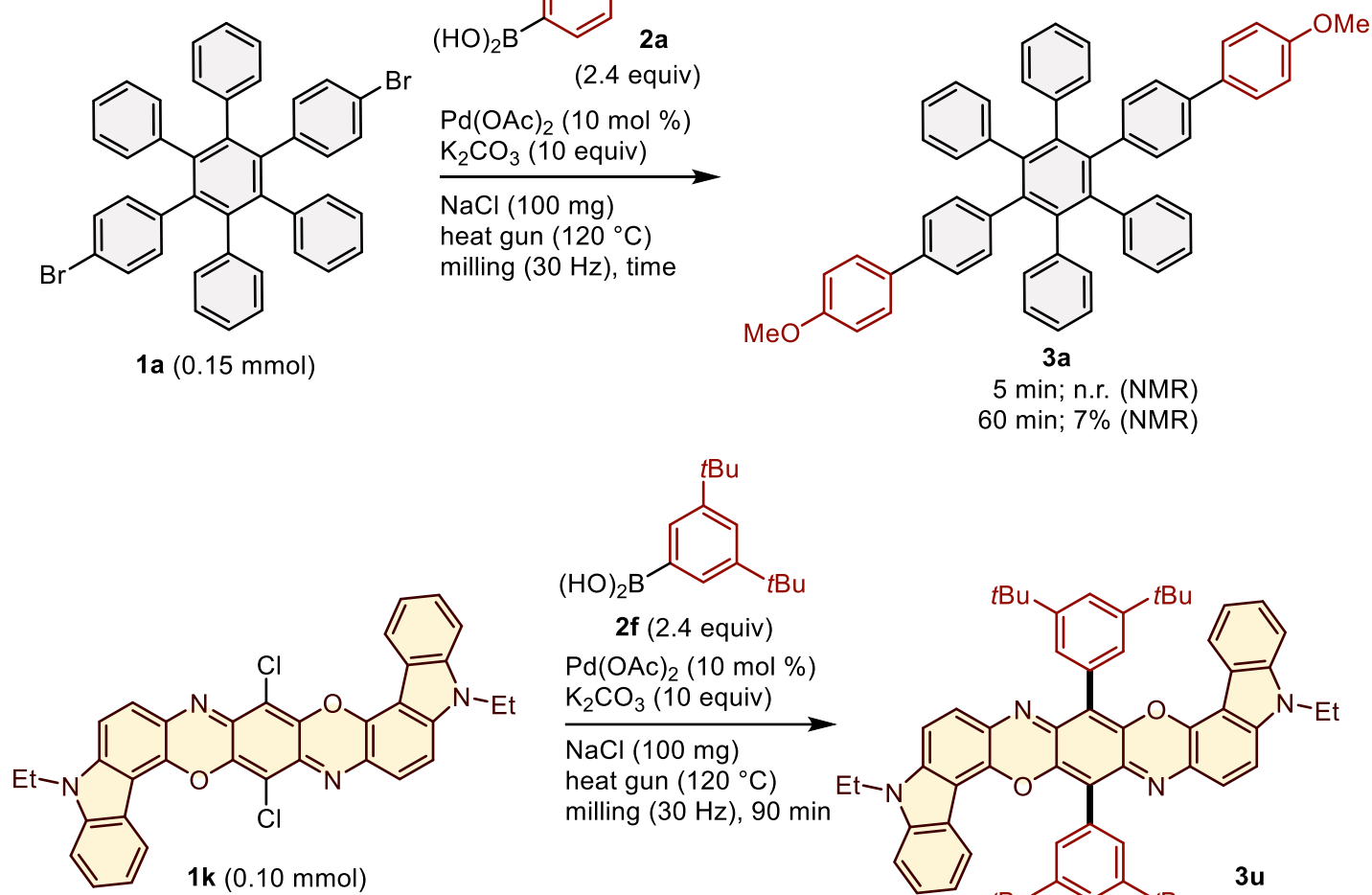<smiles></smiles>

$2 \mathrm{f}$ (2.4 equiv)

$\mathrm{Pd}(\mathrm{OAc})_{2}(10 \mathrm{~mol} \%)$

$\mathrm{K}_{2} \mathrm{CO}_{3}$ (10 equiv)

$\mathrm{NaCl}(100 \mathrm{mg})$

heat gun $\left(120^{\circ} \mathrm{C}\right)$

milling $(30 \mathrm{~Hz}), 90 \mathrm{~min}$

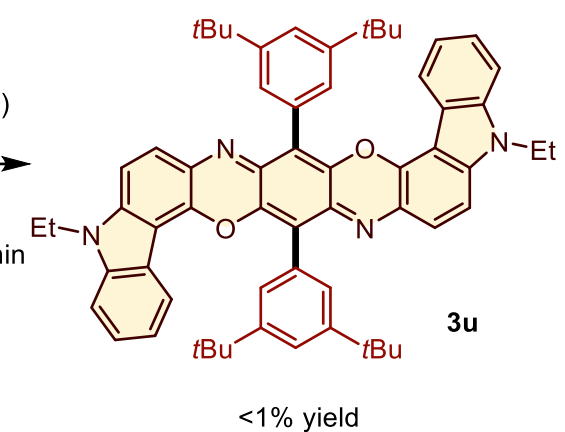

Scheme S9. The reaction under the mechanochemical conditions reported by Felipe and Stuparu ${ }^{3}$. 


\section{Reactions at higher temperature under solution-based conditions.}

We carried out the reaction of $1 \mathrm{~g}$ in $m$-xylene at $150{ }^{\circ} \mathrm{C}$ and the product $3 \mathbf{k}$ was obtained in $16 \%$, which was almost similar with the yield obtained by the reaction in toluene at $120{ }^{\circ} \mathrm{C}(19 \%)$. In addition, we also tried the reaction of $1 \mathrm{k}$ in $m$-xylene at $150^{\circ} \mathrm{C}$, but no desired product was formed.<smiles>Cc1cc(Cl)cc2c1C(=O)/C(=C1/Sc3cc(Cl)cc([N+](=O)[O-])c3C1=O)S2</smiles>

$1 \mathrm{~g}(0.10 \mathrm{mmol})$<smiles>CC(C)(C)c1cc([18OH])cc(C(C)(C)C)c1</smiles>

$2 f(2.4$ equiv)

$\mathrm{Pd}(\mathrm{OAc})_{2}(10 \mathrm{~mol} \%)$ SPhos (15 mol \%) $\mathrm{CsF}$ (6.0 equiv)

$\mathrm{H}_{2} \mathrm{O}$ (7.2 equiv) solvent $(1.0 \mathrm{~mL})$ $m$-xylene, $150{ }^{\circ} \mathrm{C}$ $24 \mathrm{~h}$<smiles>CC(C)(C)c1cc([18OH])cc(C(C)(C)C)c1</smiles>
$2 f$ (2.4 equiv) $\mathrm{Pd}(\mathrm{OAc})_{2}(10 \mathrm{~mol} \%)$ SPhos $(15 \mathrm{~mol} \%)$ CsF (6.0 equiv)

$\mathrm{H}_{2} \mathrm{O}$ (7.2 equiv) solvent $(1.0 \mathrm{~mL})$ $m$-xylene, $150^{\circ} \mathrm{C}$ $24 \mathrm{~h}$

1 k $(0.10 \mathrm{mmol})$

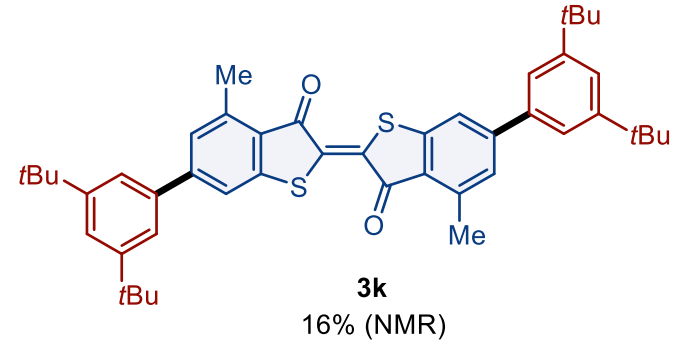

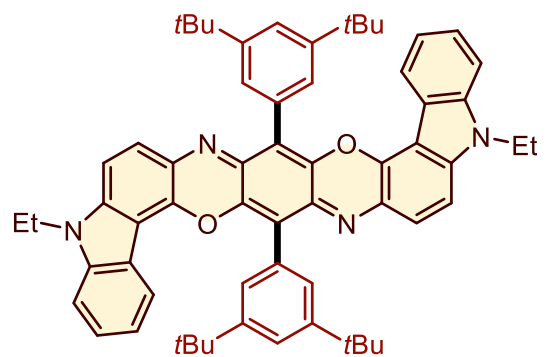

$3 \mathbf{u}$ no reaction

Scheme S10. The reactions in $p$-xylene at $150{ }^{\circ} \mathrm{C}$. 


\section{Gram-scale synthesis via the high-temperature ball milling.}

A gram-scale mechanochemical cross-coupling reaction between 1a and 2a was carried out using a stainless-steel ball-milling jar $(10 \mathrm{~mL})$ with a stainless-steel ball (diameter: $15 \mathrm{~mm})$. We found that the reaction proceeded smoothly to give the desired product $3 \mathrm{a}$ in excellent yield ( $5 \mathrm{~min}, 90 \%, 1.17$ g). We used a heat gun with a preset temperature of $250^{\circ} \mathrm{C}$, i.e., the internal reaction temperature was approximately $90{ }^{\circ} \mathrm{C}$, which was confirmed by thermography immediately after opening the milling jar.<smiles>Brc1ccc(-c2c(-c3ccccc3)c(-c3ccccc3)c(-c3ccccc3)c(-c3ccccc3)c2-c2ccc(Br)cc2)cc1</smiles>

$1 \mathrm{a}$ $1.7 \mathrm{mmol}$ $(1.18 \mathrm{~g})$<smiles>COc1ccc(O)cc1</smiles>

2a (2.4 equiv) $\mathrm{Pd}(\mathrm{OAc})_{2}(10 \mathrm{~mol} \%)$ SPhos $(15 \mathrm{~mol} \%)$ CsF (6.0 equiv)

$\mathrm{H}_{2} \mathrm{O}$ (7.2 equiv) $1,5-\operatorname{cod}(0.2 \mu \mathrm{L} / \mathrm{mg})$ milling $(30 \mathrm{~Hz}), 5 \mathrm{~min}$ preset temp.: $250^{\circ} \mathrm{C}$ internal temp.: $90^{\circ} \mathrm{C}$

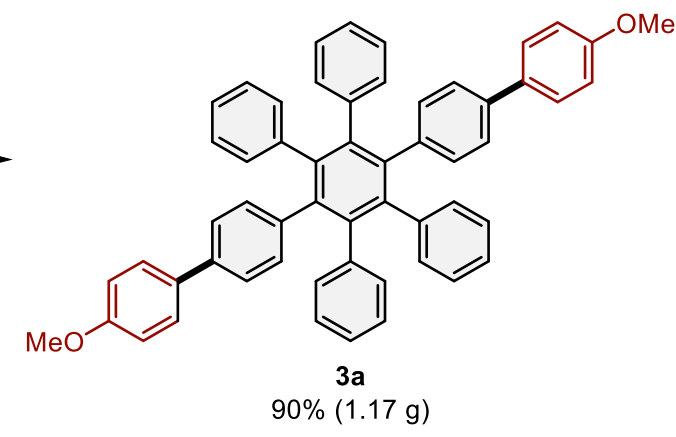

Scheme S11. Gram-scale solid-state cross-coupling under the high-temperature ball-milling conditions. 
Additive screening under mechanochemical conditions.
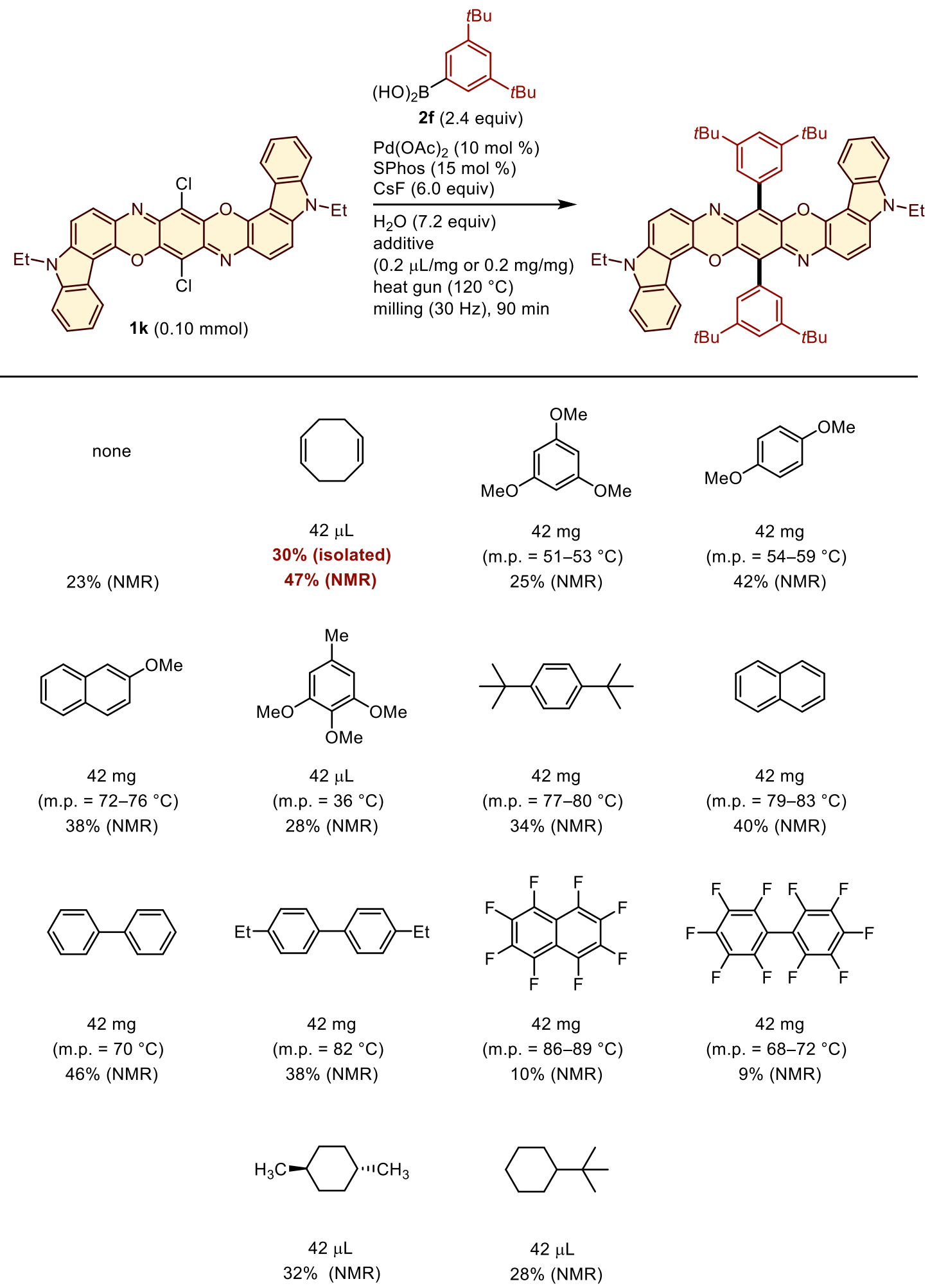

Figure S8. Additive screening under high-temperature ball-milling conditions. 


\section{Powder X-ray diffraction analysis of the crude mixture of $3 u$.}

In order to identify the reason why the yield of $\mathbf{3} \mathbf{u}$ was limited, we conducted a powder X-ray diffraction analysis of the crude mixture to see if $\mathbf{1 k}$ still remained after the reaction. The diffraction peaks derived from $1 \mathbf{k}$ were observed, suggesting that $1 \mathbf{k}$ remained after the reaction (Figure S9). We also subjected the crude mixture to a GC analysis and found that $21 \%$ of arylboronic acid $\mathbf{2 f}$ was converted into the corresponding protodeborylation product, suggesting that protodeborylation is the main reason for the low yield of $\mathbf{3 u}$. Based on these results, the main reason for the low yield of $\mathbf{3 u}$ can be expected to be due to catalyst deactivation during the reaction.
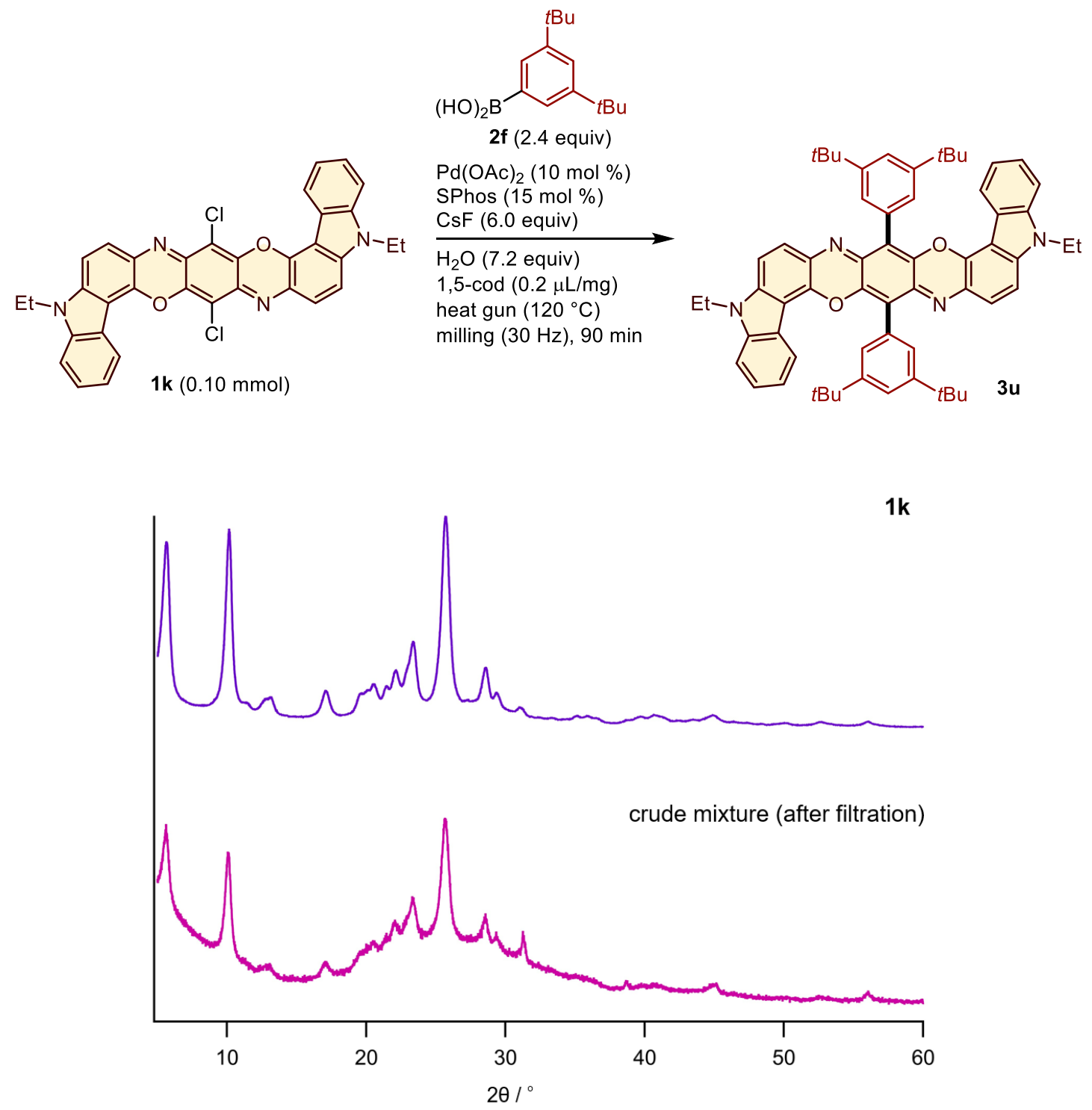

Figure S9. Powder X-ray diffraction analysis of the crude reaction mixture of $\mathbf{3 u}$. 


\section{Thermography Observation for Reaction Temperature}

The temperature inside the milling jar after the solid-state coupling reactions was confirmed by observation with a thermography camera immediately after opening the milling jar (Figure S10-S12). The crude mixtures were prepared by the following conditions: $0.15 \mathrm{mmol}$ of $1 \mathbf{a} ; 0.36 \mathrm{mmol}$ of $\mathbf{2 a}$; $0.015 \mathrm{mmol}$ of $\mathrm{Pd}(\mathrm{OAc})_{2} ; 0.023 \mathrm{mmol}$ of SPhos, $0.9 \mathrm{mmol}$ of CsF, $\mathrm{H}_{2} \mathrm{O}(20 \mu \mathrm{L}), 1,5-\operatorname{cod}(0.2 \mu \mathrm{L} / \mathrm{mg})$ in a stainless-steel ball milling jar $(1.5 \mathrm{~mL}$ ) with a stainless-steel ball $(5 \mathrm{~mm})$; heat gun (set temp.; 250 $\left.{ }^{\circ} \mathrm{C}\right), 30 \mathrm{~Hz}$. The obtained image showed that the temperature after the starting of reaction for $5 \mathrm{~min}$ was $94.3{ }^{\circ} \mathrm{C}$ (Figure S10). The temperature image was taken immediately after the jar was removed from the ball-mill with heating gun. Since the temperature inside the milling jar decreased by only 3.1 ${ }^{\circ} \mathrm{C}$ during thermography measurement (for about 10 seconds), the reaction temperature inside the jar is expected to be approximately the same as that of the thermographic image. The temperature after grinding for $15 \mathrm{~min}$ and $90 \mathrm{~min}$ was $119.0^{\circ} \mathrm{C}$ (Figure S11) and $126.1^{\circ} \mathrm{C}$ (Figure S12), respectively.

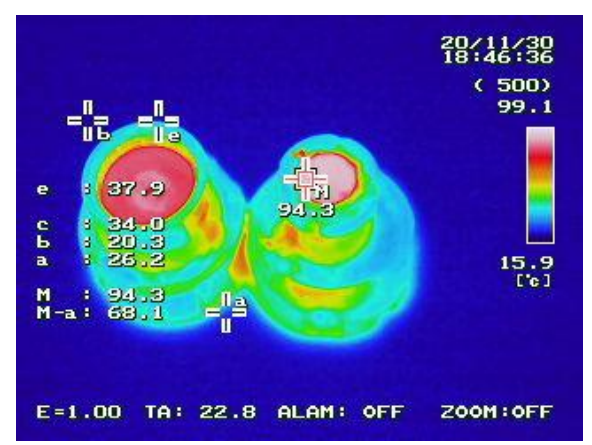

Figure S10. Thermographically derived temperature $\left(94.3^{\circ} \mathrm{C}\right)$ inside the milling jar after grinding for $5 \mathrm{~min}$ at $30 \mathrm{~Hz}$.

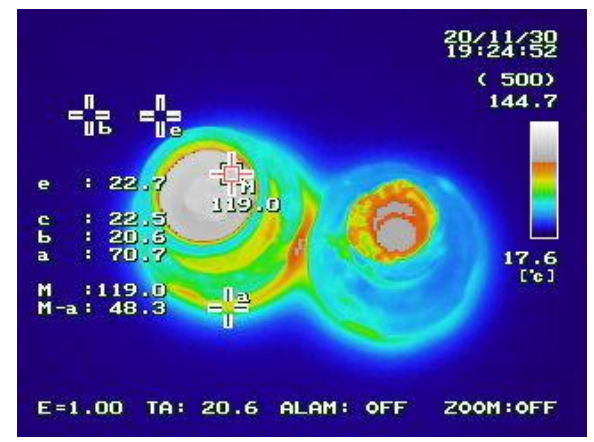

Figure S11. Thermographically derived temperature $\left(119.0^{\circ} \mathrm{C}\right)$ inside the milling jar after grinding for $15 \mathrm{~min}$ at $30 \mathrm{~Hz}$. 


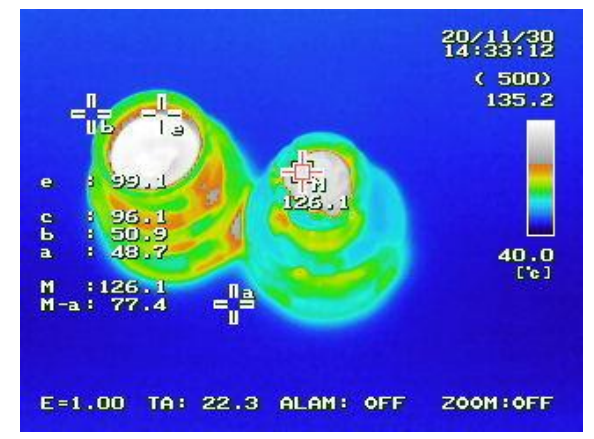

Figure S12. Thermographically derived temperature $\left(126.1^{\circ} \mathrm{C}\right)$ inside the milling jar after grinding for $90 \mathrm{~min}$ at $30 \mathrm{~Hz}$. 


\section{Solubility Evaluation of Starting Materials}

\section{Solubility evaluation of compounds classified as Class 1}

An aryl halide compound $(\mathbf{1 a}-\mathbf{1 e})$ and toluene were added vial and stirred for one hour at room temperature $\left(23{ }^{\circ} \mathrm{C}\right)$ (Figure S13). Then the mixture was filtered using a syringe filter (diameter; 32 $\mathrm{mm}$ ) and concentrated under reduced pressure until the weight of a flask with the obtained solid was not changed. The solubility was evaluated by measuring the weight of the obtained solid.

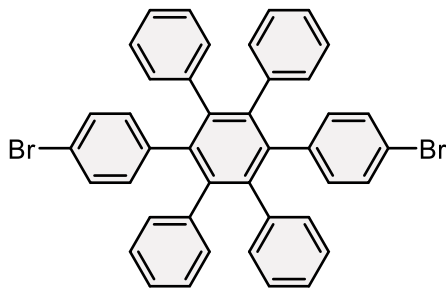

1a

$$
\text { solubility }
$$

$66.7 \mathrm{mg}$ was dissolved in toluene $(50 \mathrm{~mL})$. $1.9 \times 10^{-3} \mathrm{M}$

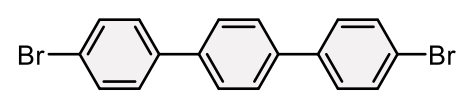

$1 \mathrm{~b}$

solubility

$28.1 \mathrm{mg}$ was dissolved in toluene $(50 \mathrm{~mL})$.

$1.5 \times 10^{-3} \mathrm{M}$

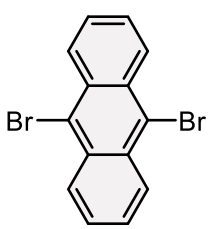

$1 c$

solubility

$12.0 \mathrm{mg}$ was dissolved

in toluene $(1.0 \mathrm{~mL})$.

$3.6 \times 10^{-2} \mathrm{M}$

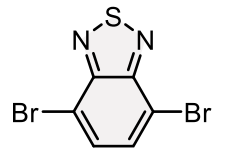

$1 d$

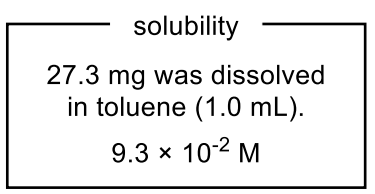

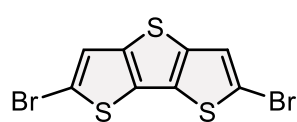

$1 \mathrm{e}$

solubility

$20.8 \mathrm{mg}$ was dissolved

in toluene $(1.0 \mathrm{~mL})$.

$5.9 \times 10^{-2} \mathrm{M}$

Figure S13. Solubility evaluation of compounds classified as Class 1. 


\section{Solubility evaluation of compounds classified as Class $\mathbf{2}$ and Class 3}

The compound $(\mathbf{1 f}-\mathbf{1 k})$ and toluene were added flask and stirred for one hour at room temperature $\left(23{ }^{\circ} \mathrm{C}\right.$ ) (Figure S14). Then the mixture was filtered using a syringe filter (diameter; $32 \mathrm{~mm}$ ) and concentrated under reduced pressure until the weight of the obtained solid was not changed. The solubility was evaluated by measuring the weight of the obtained solid.

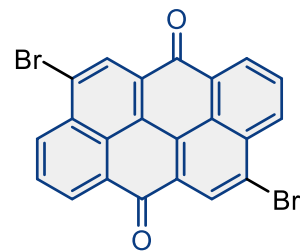

$1 f$

solubility

$5.9 \mathrm{mg}$ was dissolved in toluene $(500 \mathrm{~mL})$. $<3 \times 10^{-5} \mathrm{M}$

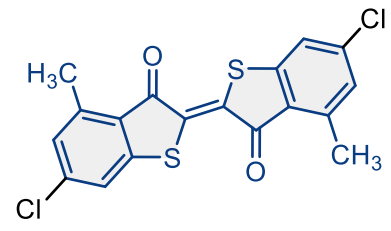

$1 \mathrm{~g}$

solubility

$20.1 \mathrm{mg}$ was dissolved in toluene $(500 \mathrm{~mL})$. $1.0 \times 10^{-4} \mathrm{M}$

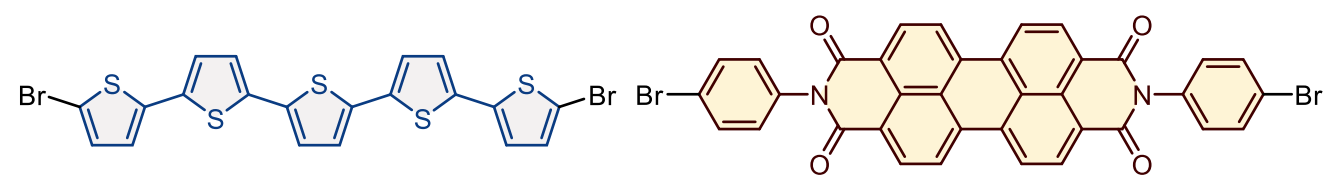

$1 \mathrm{~h}$

solubility

$1.2 \mathrm{mg}$ was dissolved in toluene $(50 \mathrm{~mL})$.

$<5 \times 10^{-5} \mathrm{M}$<smiles>O=C1Nc2cc(Br)ccc2C1=C1C(=O)Nc2cc(Br)ccc21</smiles>

1j

$1.6 \mathrm{mg}$ was dissolved in toluene $(1000 \mathrm{~mL})$. $<4 \times 10^{-6} \mathrm{M}$
$1 \mathrm{i}$

solubility

$1.2 \mathrm{mg}$ was dissolved in toluene $(500 \mathrm{~mL})$ $<4 \times 10^{-6} \mathrm{M}$

Figure S14. Solubility evaluation of compounds classified as Class 2 and Class 3. 


\section{Solubility evaluation of the reference compounds}

The compound and toluene were added flask and stirred for one hour at room temperature $\left(23^{\circ} \mathrm{C}\right)$ (Figure S15). Then the mixture was filtered using the syringe filter (diameter; $32 \mathrm{~mm}$ ) and concentrated under reduced pressure until the weight of the obtained solid was not changed. The solubility was evaluated by measuring the weight of the obtained solid. The literature value for solubility of $\mathrm{C}_{60}$ in toluene at room temperature is $4.0 \times 10^{-3} \mathrm{M}$, which is almost the same as our measured solubility $\left(4.8 \times 10^{-3} \mathrm{M}\right){ }^{4}$

$\mathrm{C}_{60}$

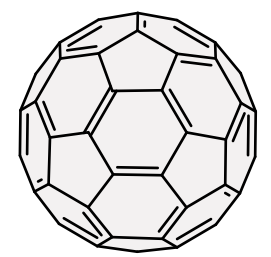

solubility

$17.1 \mathrm{mg}$ was dissolved in toluene $(5 \mathrm{~mL})$. $4.8 \times 10^{-3} \mathrm{M}$
Pentacene
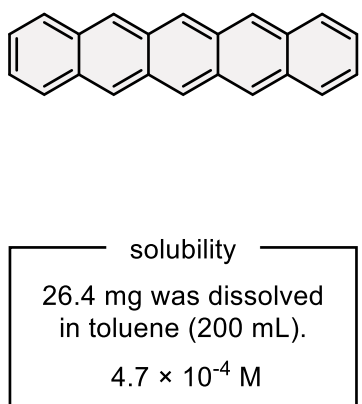

Phthalocyanine

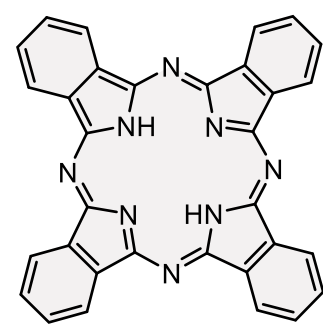

solubility

$50.0 \mathrm{mg}$ was dissolved in toluene $(500 \mathrm{~mL})$.

$1.9 \times 10^{-4} \mathrm{M}$

Figure S15. Solubility evaluation of representative compounds. 


\section{Differential Scanning Calorimetry Analysis}<smiles>Brc1ccc(-c2c(-c3ccccc3)c(-c3ccccc3)c(-c3ccccc3)c(-c3ccccc3)c2-c2ccccc2)cc1</smiles>

$1 \mathrm{a}$

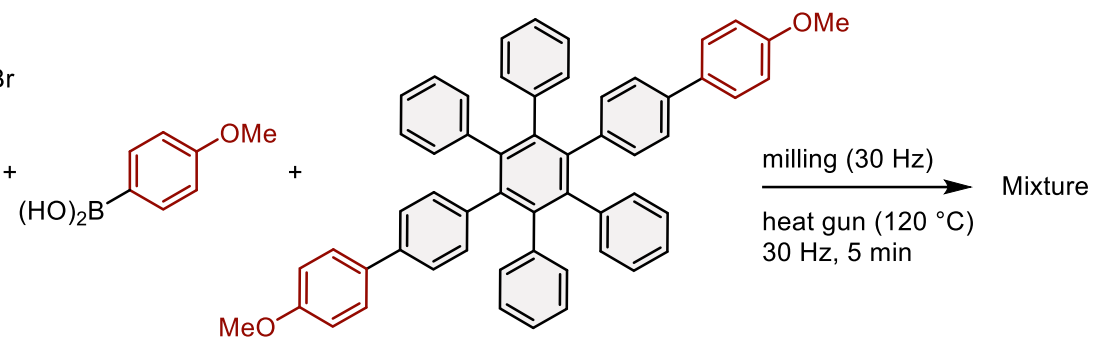

$2 \mathbf{a}$

$(\mathbf{a}: \mathbf{2 a}: \mathbf{3 a}=1: 1: 1)$

We measured differential scanning calorimetry (DSC) analysis to check the possibility of a decreasing in the melting points of 1a and 2a mixture during the mechanochemical cross-coupling reactions (Figure S16). The sample was prepared by the following conditions: 1a, 2a and 3a (1a: 2a: $\mathbf{3 a}=1: 1: 1$ ) were placed in a ball milling vessel (stainless, $1.5 \mathrm{~mL}$ ) loaded with one grinding ball (stainless, diameter: $5 \mathrm{~mm}$ ) and the mixture was milled for 5 minutes at $30 \mathrm{~Hz}$ using a heat gun with a preset temperature of $250{ }^{\circ} \mathrm{C}$. The melting points of $\mathbf{1 a}$ and $\mathbf{2 a}$ in the literature are $374{ }^{\circ} \mathrm{C}$ and $208{ }^{\circ} \mathrm{C}$, respectively. From the result of DSC analysis, the melting points of 1a and 2a in the mixture did not change significantly $\left(\mathbf{1 a} ; 353.2{ }^{\circ} \mathrm{C}, \mathbf{2 a} ; 208.6{ }^{\circ} \mathrm{C}\right)$, indicating that the observed acceleration effect by external heating would not be due to the melting of the reactants because the internal reaction temperature of $120^{\circ} \mathrm{C}$.

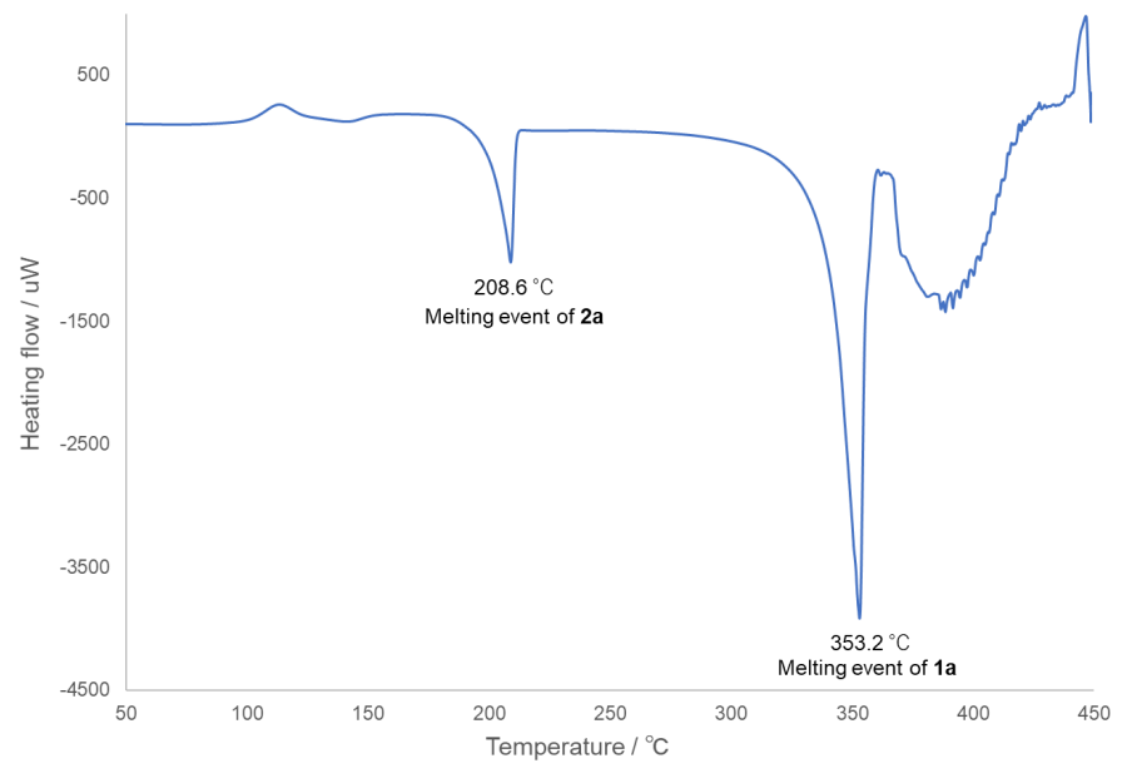

Figure S16. DSC profiles of the mixture (1a, 2a and 3a) after grinding under the mechanochemical heating conditions. Heating rate was $10{ }^{\circ} \mathrm{C} / \mathrm{min}$, and temperature was programmed from $30{ }^{\circ} \mathrm{C}$ to $450{ }^{\circ} \mathrm{C}$. The sample amount was $4.0 \mathrm{mg}$. 
10. Optical Measurements

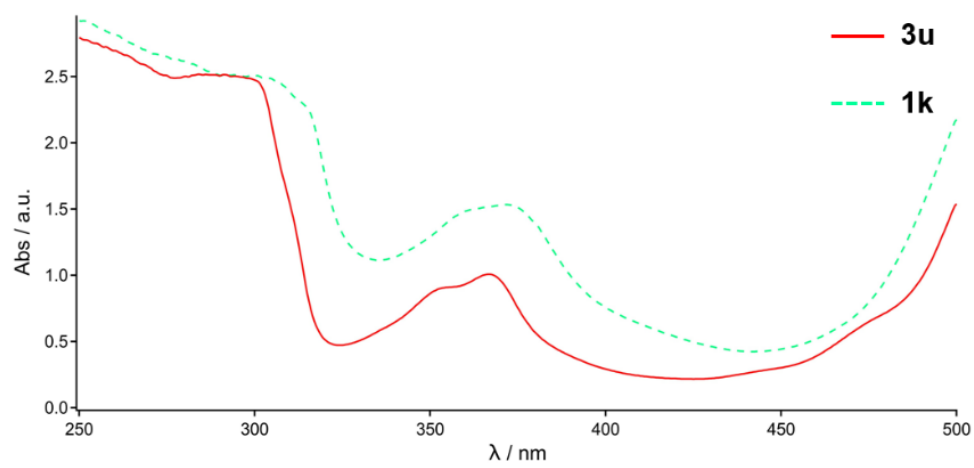

Figure S17. Absorption spectra of the slurry solution of $\mathbf{1 k}$ (green line) and the diluted solution $\left(10^{-4}\right.$ $\mathrm{M})$ of $3 \mathbf{u}$ (red line) in $\mathrm{CH}_{2} \mathrm{Cl}_{2}$.

a)

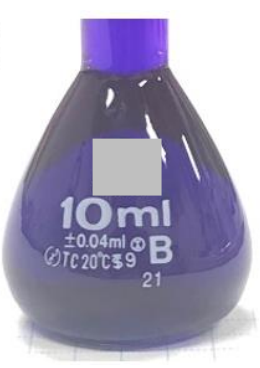

b)

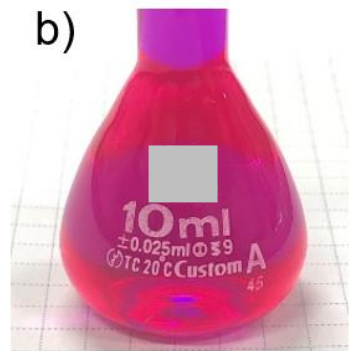

Figure S18. Photographs of the slurry solution of a) $1 \mathbf{k}$ and the diluted solution $\left(10^{-4} \mathrm{M}\right)$ of b) $3 \mathbf{u}$ in $\mathrm{CH}_{2} \mathrm{Cl}_{2}$.

a)

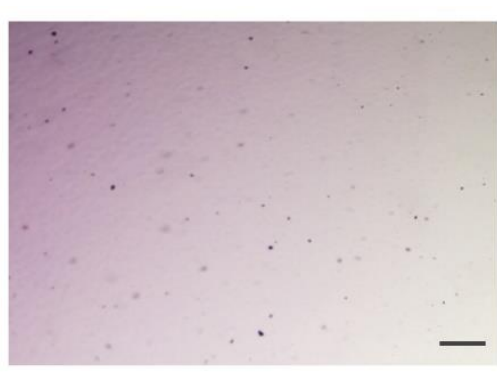

b)

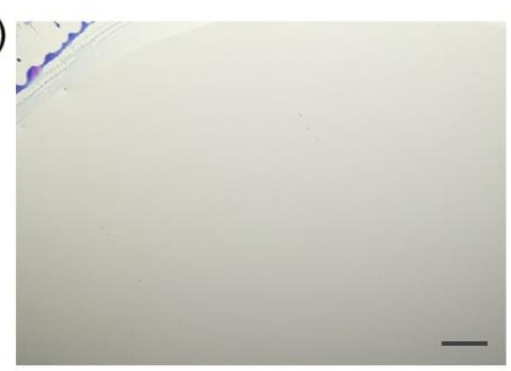

Figure S19. Photographs of the slurry solution of a) $1 \mathbf{k}$ and the diluted solution $\left(10^{-4} \mathrm{M}\right)$ of b) $\mathbf{3} \mathbf{u}$ in $\mathrm{CH}_{2} \mathrm{Cl}_{2}$. Undissolved particles were confirmed in the slurry solution of $\mathbf{1 k}$. Scale bar is $200 \mu \mathrm{m}$. 


\section{Single Crystal X-ray Structure Analyses}

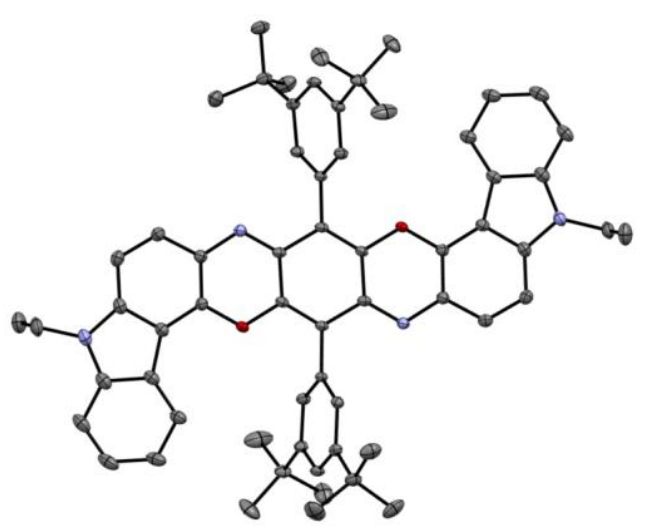

Figure S20. Molecular structure of 3u (thermal ellipsoids at 50\% probability; hydrogen atoms and $\mathrm{CH}_{2} \mathrm{Cl}_{2}$ are omitted for clarity).

Table S2. Summary of X-ray crystallographic data for $\mathbf{3 u}$.

\begin{tabular}{|c|c|}
\hline CCDC Number & 2052088 \\
\hline Empirical Formula & $\mathrm{C}_{65} \mathrm{H}_{70} \mathrm{Cl}_{6} \mathrm{~N}_{4} \mathrm{O}_{2}$ \\
\hline Formula Weight & 1151.95 \\
\hline Crystal Size / mm & $0.24 \times 0.24 \times 0.18$ \\
\hline Crystal System & triclinic \\
\hline$a / \AA$ & $13.1281(3)$ \\
\hline$b / \AA$ & $13.6926(3)$ \\
\hline$c / \AA$ & $17.6369(4)$ \\
\hline$\alpha /^{\circ}$ & $81.250(2)$ \\
\hline$\beta /^{\circ}$ & $70.755(2)$ \\
\hline$\gamma /{ }^{\circ}$ & $84.673(2)$ \\
\hline$V / \AA^{3}$ & 2955.27(12) \\
\hline Space Group & $P-1(\# 2)$ \\
\hline$Z$ value & 2 \\
\hline$D_{\text {calc }} / \mathrm{g} \mathrm{cm}^{-3}$ & 1.295 \\
\hline Temperature / K & 123 \\
\hline $2 \theta_{\max } /^{\circ}$ & 58.58 \\
\hline$\mu / \mathrm{mm}^{-1}$ & $0.339\left(\mathrm{Mo} \mathrm{K}_{\alpha}\right)$ \\
\hline No. of reflections & $\begin{array}{l}\text { Total: } 45952 \\
\text { Unique: } 13709 \\
R_{\text {int }}=0.0248\end{array}$ \\
\hline$R_{1}^{a}$ & 0.0553 \\
\hline$w R_{2}^{b}$ & 0.1586 \\
\hline $\mathrm{GOF}^{\mathrm{c}}$ & 1.038 \\
\hline Max./Mini. peak $I / \AA^{3}$ & $1.19 \mathrm{e}^{-/-0.92 \mathrm{e}^{-}}$ \\
\hline
\end{tabular}




\section{Characterization of Coupling Products.}

4,4"''-Dimethoxy-2",3",5",6"-tetraphenyl-1,1':4',1":4",1"':4"',1"'"-quinquephenyl (3a).<smiles>COc1ccc(-c2ccc(-c3c(-c4ccccc4)c(-c4ccccc4)c(-c4ccccc4)c(-c4ccccc4)c3-c3ccccc3)cc2)cc1</smiles>

The reaction was performed according to the general procedure $\mathrm{A}$. The reaction was carried out with $103.9 \mathrm{mg}(0.15 \mathrm{mmol})$ of $\mathbf{1 a}$ and $54.7 \mathrm{mg}(0.36 \mathrm{mmol})$ of $\mathbf{2 a}$. The product 3a was obtained as a white powder (110.9 mg, $0.149 \mathrm{mmol}, 99 \%$ yield) after purification by_reprecipitation from $\mathrm{CH}_{2} \mathrm{Cl}_{2} / \mathrm{MeOH}_{\text {. }}$ ${ }^{1} \mathrm{H}$ NMR (400 MHz, $\left.\mathrm{CDCl}_{3}, \delta\right): 3.80$ (s, 6H), 6.79-6.90 (m, 28H), 7.08 (d, $\left.J=8.4 \mathrm{~Hz}, 4 \mathrm{H}\right), 7.35$ (d, $J$ $=7.2 \mathrm{~Hz}, 4 \mathrm{H}) \cdot{ }^{13} \mathrm{C}$ NMR $\left(100 \mathrm{MHz}, \mathrm{CDCl}_{3}, \delta\right): 55.5\left(\mathrm{CH}_{3}\right), 114.1(\mathrm{CH}), 124.8(\mathrm{CH}), 125.3(\mathrm{CH})$, $126.8(\mathrm{CH}), 127.8(\mathrm{CH}), 131.6(\mathrm{CH}), 131.9(\mathrm{CH}), 133.5(C), 137.1(C), 139.2(C), 140.2(C), 140.6$ (C), 140.8 (C), 159.0 (C). ${ }^{13} \mathrm{C}$ NMR peaks were relatively weak because of the low solubility of $\mathbf{3 a}$. HRMS-ESI $(\mathrm{m} / \mathrm{z})$ : $[\mathrm{M}+\mathrm{Na}]^{+}$calcd for $\mathrm{C}_{56} \mathrm{H}_{42} \mathrm{O}_{2} \mathrm{Na}, 769.3077$; found, 769.3086. $\mathrm{mp}>400{ }^{\circ} \mathrm{C}$.

\section{4,4"-Di(naphthalen-1-yl)-1,1':4',1"'-terphenyl (3b).}

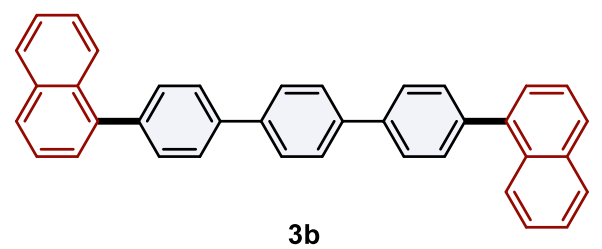

The reaction was performed according to the general procedure $\mathrm{A}$. The reaction was carried out with $58.2 \mathrm{mg}(0.15 \mathrm{mmol})$ of $\mathbf{1 b}$ and $61.9 \mathrm{mg}(0.36 \mathrm{mmol})$ of $\mathbf{2} \mathbf{b}$. The product $\mathbf{3} \mathbf{b}$ was obtained as a white powder (70.8 mg, $0.147 \mathrm{mmol}, 98 \%$ yield) after pulification by reprecipitation from $\mathrm{CH}_{2} \mathrm{Cl}_{2} / \mathrm{MeOH}$. ${ }^{1} \mathrm{H}$ and ${ }^{13} \mathrm{C}$ NMR were in agreement with the literature. ${ }^{5}$

${ }^{1} \mathrm{H}$ NMR (400 MHz, $\mathrm{CDCl}_{3}, \delta$ ): 7.44-7.59 (m, 8H), 7.63 (d, J=8.0 Hz, 4H), 7.78-7.86 (m, 8H), 7.90 (d, $J=8.4 \mathrm{~Hz}, 2 \mathrm{H}), 7.94(\mathrm{~d}, J=8.0 \mathrm{~Hz}, 2 \mathrm{H}), 8.02(\mathrm{~d}, J=8.8 \mathrm{~Hz}, 2 \mathrm{H}) .{ }^{13} \mathrm{C} \mathrm{NMR}\left(101 \mathrm{MHz}, \mathrm{CDCl}_{3}\right.$,

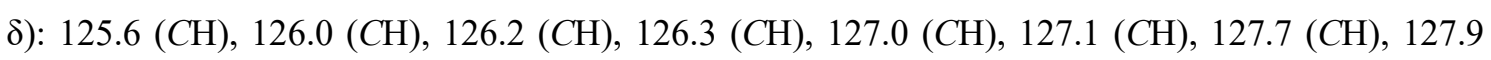
$(\mathrm{CH}), 128.5(\mathrm{CH}), 130.7(\mathrm{CH}), 131.7(\mathrm{C}), 134.0(\mathrm{C}), 139.7(\mathrm{C}), 139.9(\mathrm{C}), 140.0(\mathrm{C})$. HRMS-EI $(\mathrm{m} / \mathrm{z})$ : $[\mathrm{M}]^{+}$calcd for $\mathrm{C}_{38} \mathrm{H}_{26}, 482.2035$; found, 482.2021. mp 232-235 ${ }^{\circ} \mathrm{C}$. 
$N 4, N 4, N 4 " ',, N 4$ "''-Tetraphenyl-[1,1':4',1":4",1"':4"',1"''-quinquephenyl]-4,4"'"-diamine (3c).

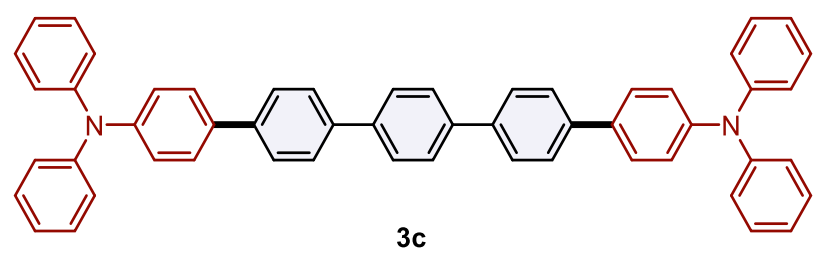

The reaction was performed according to the general procedure A. The reaction was carried out with $58.2 \mathrm{mg}(0.15 \mathrm{mmol})$ of $\mathbf{1 b}$ and $104.1 \mathrm{mg}(0.36 \mathrm{mmol})$ of $\mathbf{2 c}$. The product $\mathbf{3 c}$ was obtained as a white powder (98.9 mg, $0.138 \mathrm{mmol}, 92 \%$ yield) after pulification by reprecipitation from $\mathrm{CH}_{2} \mathrm{Cl}_{2} / \mathrm{MeOH}$. ${ }^{1} \mathrm{H}$ and ${ }^{13} \mathrm{C}$ NMR were in agreement with the literature. ${ }^{5}$

${ }^{1} \mathrm{H}$ NMR $\left(400 \mathrm{MHz}, \mathrm{CDCl}_{3}, \delta\right): 7.05(\mathrm{t}, J=7.4 \mathrm{~Hz}, 4 \mathrm{H}), 7.13-7.19(\mathrm{~m}, 13 \mathrm{H}), 7.28-7.32(\mathrm{~m}, 7 \mathrm{H}), 7.54$ (d, $J=8.8 \mathrm{~Hz}, 4 \mathrm{H}), 7.62-7.77$ (m, $12 \mathrm{~Hz}) .{ }^{13} \mathrm{C} \mathrm{NMR}\left(100 \mathrm{MHz}, \mathrm{CDCl}_{3}, \delta\right): 123.1(\mathrm{CH}), 124.0(\mathrm{CH})$, 124.6 (CH), $127.2(\mathrm{CH}), 127.5(\mathrm{CH}), 127.8(\mathrm{CH}), 129.4(\mathrm{CH}), 134.6(C), 139.1(C), 139.7(C), 139.8$ (C), $147.4(C), 147.8(C) .{ }^{13} \mathrm{C}$ NMR peaks were relatively weak because of the low solubility of $\mathbf{3 c}$. HRMS-ESI $(\mathrm{m} / \mathrm{z})$ : $[\mathrm{M}]^{+}$calcd for $\mathrm{C}_{54} \mathrm{H}_{40} \mathrm{~N}_{2}, 716.3186$; found, 716.3200. mp 287-294 ${ }^{\circ} \mathrm{C}$.

\section{9,10-Bis[4-(pyren-1-yl)phenyl]anthracene (3d).}

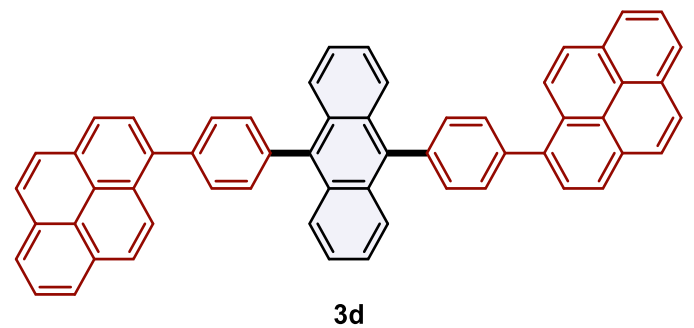

The reaction was performed according to the general procedure A. The reaction was carried out with $33.6 \mathrm{mg}(0.10 \mathrm{mmol})$ of $\mathbf{1 c}$ and $77.3 \mathrm{mg}(0.24 \mathrm{mmol})$ of $\mathbf{2 d}$. The product $\mathbf{3 d}$ was obtained as a white powder (71.3 mg, $0.098 \mathrm{mmol}, 98 \%$ yield) after purification by reprecipitation from $\mathrm{CH}_{2} \mathrm{Cl}_{2} / \mathrm{MeOH}$. ${ }^{1} \mathrm{H}$ NMR (396 MHz, $\left.\mathrm{CDCl}_{3}, \delta\right): 7.51$ (dd, $\left.J=3.2,7.1 \mathrm{~Hz}, 4 \mathrm{H}\right), 7.74(\mathrm{~d}, J=7.5 \mathrm{~Hz}, 4 \mathrm{H}), 7.93$ (d, $J=$ $7.9 \mathrm{~Hz}, 4 \mathrm{H}), 7.99$ (dd, $J=3.2,6.7 \mathrm{~Hz}, 3 \mathrm{H}), 8.07$ (t, $J=7.7 \mathrm{~Hz}, 2 \mathrm{H}), 8.13-8.21(\mathrm{~m}, 6 \mathrm{H}), 8.21-8.29$ (m, $7 \mathrm{H}), 8.35(\mathrm{~d}, J=7.5 \mathrm{~Hz}, 2 \mathrm{H}), 8.49(\mathrm{~d}, J=9.1 \mathrm{~Hz}, 2 \mathrm{H}) .{ }^{13} \mathrm{C} \mathrm{NMR}\left[100 \mathrm{MHz}, \mathrm{C}_{2} \mathrm{D}_{2} \mathrm{Cl}_{4}\left(120{ }^{\circ} \mathrm{C}\right), \delta\right]:$ 124.6 (CH), $124.8(\mathrm{CH}), 125.1(\mathrm{CH}), 125.2(\mathrm{CH}), 125.9(\mathrm{CH}), 126.9(\mathrm{CH}), 127.3(\mathrm{CH}), 127.46(\mathrm{CH})$, $127.53(\mathrm{CH}), 127.6(\mathrm{CH}), 127.7(\mathrm{CH}), 128.6(C), 130.2(C), 130.4(\mathrm{CH}), 130.66(C), 130.7(C), 130.9$ (C), $131.0(C), 131.4(C H), 131.5(C), 136.9$ (C), 137.5 (C), $138.0(C), 140.3(C) .{ }^{13}$ C NMR peaks were relatively weak because of the low solubility of 3d. HRMS-ESI $(\mathrm{m} / \mathrm{z})$ : $[\mathrm{M}]^{+}$calcd for $\mathrm{C}_{58} \mathrm{H}_{34}$,

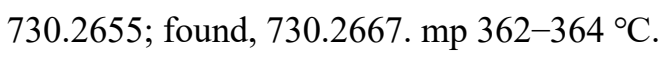


4,4'-(Benzo[c][1,2,5]thiadiazole-4,7-diyl)bis( $N, N$-diphenylaniline) (3e).

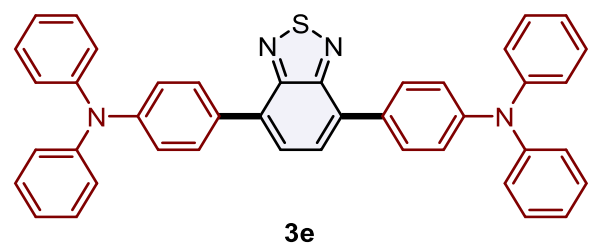

The reaction was performed according to the general procedure A. The reaction was carried out with $44.1 \mathrm{mg}(0.15 \mathrm{mmol})$ of $\mathbf{1 d}$ and $104.1 \mathrm{mg}(0.36 \mathrm{mmol})$ of $\mathbf{2 c}$. The product $\mathbf{3 e}$ was obtained as a red powder ( $92.5 \mathrm{mg}, 0.148 \mathrm{mmol}, 99 \%$ yield) after pulification by silica-gel column chromatography $\left(\mathrm{SiO}_{2}, \mathrm{CH}_{2} \mathrm{Cl}_{2} /\right.$ hexane, 0:100-40:60). ${ }^{1} \mathrm{H}$ and ${ }^{13} \mathrm{C}$ NMR were in agreement with the literature. ${ }^{6}$

${ }^{1} \mathrm{H} \mathrm{NMR}\left(396 \mathrm{MHz}, \mathrm{CDCl}_{3}, \delta\right): 7.07$ (t, $\left.J=7.3 \mathrm{~Hz}, 4 \mathrm{H}\right), 7.21$ (t, $\left.J=8.7 \mathrm{~Hz}, 12 \mathrm{H}\right), 7.30$ (t, $J=7.9 \mathrm{~Hz}$, 8H), $7.75(\mathrm{~s}, 2 \mathrm{H}), 7.85-7.91(\mathrm{~m}, 4 \mathrm{H}) .{ }^{13} \mathrm{C}$ NMR $\left(99 \mathrm{MHz}, \mathrm{CDCl}_{3}, \delta\right): 123.1(\mathrm{CH}), 123.4(\mathrm{CH}), 125.0$ $(C H), 127.5(C H), 129.5(C H), 130.0(C H), 131.1(C), 132.2(C), 147.6(C), 148.1(C), 154.3(C)$. HRMS-EI $(m / z)$ : $[\mathrm{M}]^{+}$calcd for $\mathrm{C}_{42} \mathrm{H}_{30} \mathrm{~N}_{4} \mathrm{~S}, 622.2191$; found, 622.2177. mp 228-232 ${ }^{\circ} \mathrm{C}$.

\section{4,4'-(Dithieno[3,2-b:2',3'-d]thiophene-2,6-diyl)bis( $N, N$-diphenylaniline) (3f).}

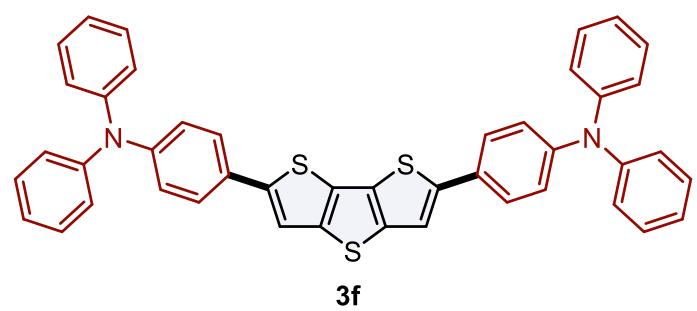

The reaction was performed according to the general procedure A. The reaction was carried out with $53.1 \mathrm{mg}(0.15 \mathrm{mmol})$ of $\mathbf{1 e}$ and $104.1 \mathrm{mg}(0.36 \mathrm{mmol})$ of $\mathbf{2 c}$. The product $\mathbf{3 f}$ was obtained as a yellow powder ( $81.9 \mathrm{mg}, 0.120 \mathrm{mmol}, 80 \%$ yield) after pulification by silica-gel column chromatography $\left(\mathrm{SiO}_{2}, \mathrm{CH}_{2} \mathrm{Cl}_{2} /\right.$ hexane, 0:100-40:60). ${ }^{1} \mathrm{H}$ and ${ }^{13} \mathrm{C}$ NMR were in agreement with the literature. ${ }^{7}$

${ }^{1} \mathrm{H}$ NMR (400 MHz, $\mathrm{CDCl}_{3}, \delta$ ): 7.03-7.11 (m, 9H), 7.12-7.17 (m, 9H), 7.28-7.31 (m, 6H), 7.40 (s, 2H), $7.49(\mathrm{~d}, J=8.4 \mathrm{~Hz}, 4 \mathrm{H}) .{ }^{13} \mathrm{C} \mathrm{NMR}\left(101 \mathrm{MHz}, \mathrm{CDCl}_{3}, \delta\right): 115.6(\mathrm{CH}), 115.7(\mathrm{CH}), 123.4(\mathrm{CH})$, $123.60(\mathrm{CH}), 123.62(\mathrm{CH}), 124.8(\mathrm{CH}), 126.6(\mathrm{CH}), 128.5(\mathrm{C}), 129.5(\mathrm{CH}), 129.8(C), 141.6(C)$, $144.9(C), 147.5(C), 147.7(C) .{ }^{13} \mathrm{C}$ NMR peaks were relatively weak because of the low solubility of 3f. HRMS-ESI $(m / z)$ : $[\mathrm{M}]^{+}$calcd for $\mathrm{C}_{44} \mathrm{H}_{30} \mathrm{~N}_{2} \mathrm{~S}_{3}, 682.1566$; found, 682.1570. $\mathrm{mp} 274-275^{\circ} \mathrm{C}$. 
4,10-Bis(3,5-di-tert-butylphenyl)naphtho[7,8,1,2,3-nopqr]tetraphene-6,12-dione (3g).

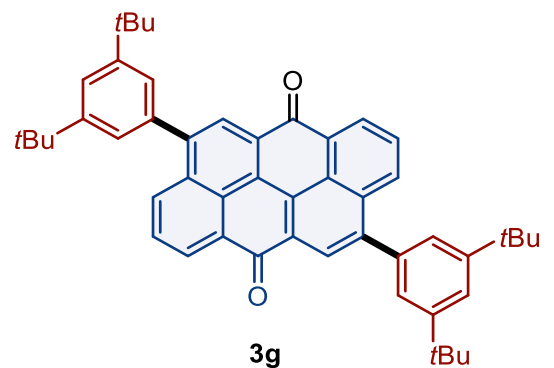

The reaction was performed according to the general procedure B. The reaction was carried out with $69.6 \mathrm{mg}(0.15 \mathrm{mmol})$ of $\mathbf{1 f}$ and $84.3 \mathrm{mg}(0.36 \mathrm{mmol})$ of $\mathbf{2} \mathbf{f}$. The product $\mathbf{3 g}$ was obtained as a red powder ( $77.3 \mathrm{mg}, 0.113 \mathrm{mmol}, 72 \%$ yield) after purification by silica-gel column chromatography $\left(\mathrm{SiO}_{2}, \mathrm{CH}_{2} \mathrm{Cl}_{2} /\right.$ hexane, 0:100-50:50).

${ }^{1} \mathrm{H}$ NMR (396 MHz, $\left.\mathrm{CDCl}_{3}, \delta\right): 1.44$ (s, 36H), $7.45(\mathrm{~d}, J=2.0 \mathrm{~Hz}, 4 \mathrm{H}), 7.58(\mathrm{t}, J=1.8 \mathrm{~Hz}, 2 \mathrm{H}), 7.77$ (t, $J=8.1 \mathrm{~Hz}, 2 \mathrm{H}), 8.34(\mathrm{dd}, J=1.0,8.5 \mathrm{~Hz}, 2 \mathrm{H}), 8.44(\mathrm{~s}, 2 \mathrm{H}), 8.65(\mathrm{~d}, J=6.3 \mathrm{~Hz}, 2 \mathrm{H}) .{ }^{13} \mathrm{C} \mathrm{NMR}$ (100 MHz, $\left.\mathrm{CDCl}_{3}, \delta\right): 31.8\left(\mathrm{CH}_{3}\right), 35.2(\mathrm{C}), 122.1(\mathrm{CH}), 124.76(\mathrm{CH}), 124.83(\mathrm{CH}), 126.7(\mathrm{C}), 127.8$ (C), $128.5(\mathrm{CH}), 129.1(\mathrm{C}), 129.2(\mathrm{C}), 130.4(\mathrm{CH}), 133.3(\mathrm{C}), 134.3(\mathrm{CH}), 138.5(\mathrm{C}), 144.3(\mathrm{C}), 151.0$ (C), $182.9(C)$. HRMS-ESI $(m / z)$ : $[\mathrm{M}+\mathrm{Na}]^{+}$calcd for $\mathrm{C}_{50} \mathrm{H}_{50} \mathrm{O}_{2} \mathrm{Na}, 705.3703$; found, 705.3708. $\mathrm{mp}$ $>400{ }^{\circ} \mathrm{C}$.

\section{4,10-Bis[3,5-bis(trimethylsilyl)phenyl]naphtho[7,8,1,2,3-nopqr]tetraphene-6,12-dione (3h).}<smiles></smiles>

The reaction was performed according to the general procedure $\mathrm{B}$. The reaction was carried out with $69.1 \mathrm{mg}(0.15 \mathrm{mmol})$ of $\mathbf{1 f}$ and $125.4 \mathrm{mg}(0.36 \mathrm{mmol})$ of $\mathbf{2 g}$. The product $\mathbf{3 h}$ was obtained as a red powder (78.5 mg, $0.105 \mathrm{mmol}, 70 \%$ yield) after purification by silica-gel column chromatography $\left(\mathrm{SiO}_{2}, \mathrm{CH}_{2} \mathrm{Cl}_{2} /\right.$ hexane, 0:100-30:70).

${ }^{1} \mathrm{H}$ NMR (392 MHz, $\left.\mathrm{CDCl}_{3}, \delta\right): 0.36$ (s, 36H), 7.72 (s, 4H), 7.79-7.88 (m, 4H), 8.34 (d, J=8.2 Hz, 2H), 8.54 (s, 2H), $8.82(\mathrm{~d}, J=7.1 \mathrm{~Hz}, 2 \mathrm{H}) .{ }^{13} \mathrm{C} \mathrm{NMR}\left(100 \mathrm{MHz}, \mathrm{CDCl}_{3}, \delta\right):-0.81\left(\mathrm{CH}_{3}\right), 124.8(\mathrm{CH})$, $126.9(C), 127.8(C), 128.6(C H), 129.2(C), 130.5(C H), 133.2(C), 134.0(C H), 135.8(C H), 137.8$ (C), $138.0(C H), 139.9(C), 143.9(C), 182.8(C)$. HRMS-ESI $(m / z):[M]^{+}$calcd for $\mathrm{C}_{46} \mathrm{H}_{51} \mathrm{O}_{2} \mathrm{Si}_{4}$, 747.2961; found, $747.2977 . \mathrm{mp} 358-362^{\circ} \mathrm{C}$. 


\section{4,10-Bis(3,3",5,5"'-tetra-tert-butyl-[1,1':3',1"'-terphenyl]-5'-yl)naphtho[7,8,1,2,3-}

\section{nopqr]tetraphene-6,12-dione (3i).}

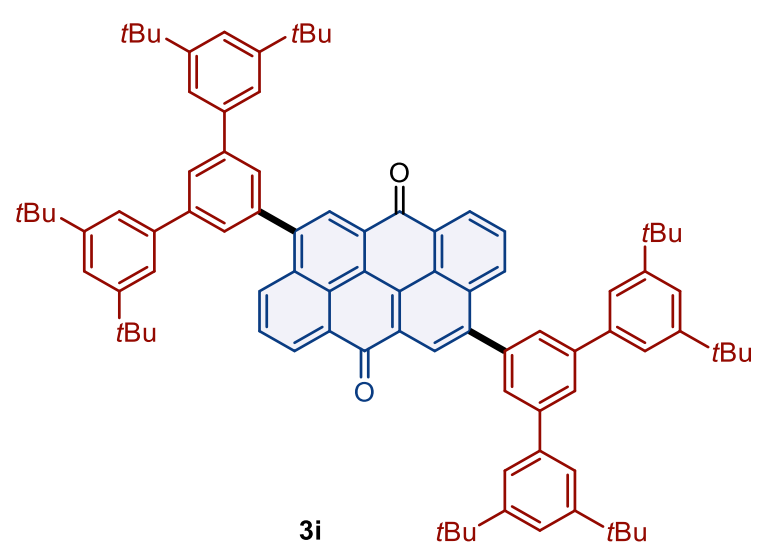

The reaction was performed according to the general procedure $\mathrm{B}$. The reaction was carried out with $46.4 \mathrm{mg}(0.10 \mathrm{mmol})$ of $\mathbf{1} \mathbf{f}$ and $139.4 \mathrm{mg}(0.24 \mathrm{mmol})$ of $\mathbf{2 h}$. The product $\mathbf{3 i}$ was obtained as a red powder ( $86.0 \mathrm{mg}, 0.071 \mathrm{mmol}, 71 \%$ yield) after purification by silica-gel column chromatography $\left(\mathrm{SiO}_{2}, \mathrm{CH}_{2} \mathrm{Cl}_{2} /\right.$ hexane, 0:100-20:80).

${ }^{1} \mathrm{H}$ NMR (400 MHz, $\mathrm{CDCl}_{3}, \delta$ ): 1.40 (s, 72H), 7.52 (s, 4H), 7.56 (s, 8H), 7.79 (s, 4H), 7.85 (t, J=8.0 $\mathrm{Hz}, 2 \mathrm{H}), 7.94(\mathrm{~s}, 2 \mathrm{H}), 8.54(\mathrm{~d}, J=8.4 \mathrm{~Hz}, 2 \mathrm{H}), 8.67(\mathrm{~s}, 2 \mathrm{H}), 8.83$ (d, $J=7.2 \mathrm{~Hz}, 2 \mathrm{H}) .{ }^{13} \mathrm{C}$ NMR $(100$ MHz, $\left.\mathrm{CDCl}_{3}, \delta\right): 31.7\left(\mathrm{CH}_{3}\right), 35.2(C), 122.0(\mathrm{CH}), 122.2(\mathrm{CH}), 125.1(\mathrm{CH}), 126.8(\mathrm{CH}), 127.1(\mathrm{C})$, $127.9(\mathrm{C}), 128.4(\mathrm{CH}), 128.9(\mathrm{CH}), 129.3(\mathrm{C}), 129.4(\mathrm{C}), 130.6(\mathrm{CH}), 133.0(\mathrm{C}), 134.3(\mathrm{CH}), 140.0$ (C), $140.7(C), 143.3(C), 143.4(C), 151.6(C), 182.7(C)$. HRMS-ESI $(m / z)$ : $[\mathrm{M}]^{+}$calcd for $\mathrm{C}_{90} \mathrm{H}_{98} \mathrm{O}_{2}$, 1210.7572; found, $1210.7601 . \mathrm{mp}>400{ }^{\circ} \mathrm{C}$. 


\section{4,10-Bis[4-(diphenylamino)phenyl]naphtho[7,8,1,2,3-nopqr]tetraphene-6,12-dione (3j).}<smiles></smiles>

The reaction was performed according to the general procedure $\mathrm{B}$. The reaction was carried out with $69.6 \mathrm{mg}(0.15 \mathrm{mmol})$ of $\mathbf{1 f}$ and $104.1 \mathrm{mg}(0.36 \mathrm{mmol})$ of $\mathbf{2 c}$. The product $\mathbf{3 j}$ was obtained as a red powder ( $99.0 \mathrm{mg}, 0.125 \mathrm{mmol}, 83 \%$ yield) after purification by silica-gel column chromatography $\left(\mathrm{SiO}_{2}, \mathrm{CH}_{2} \mathrm{Cl}_{2} /\right.$ hexane, 50:50-100:0).

${ }^{1} \mathrm{H}$ NMR (396 MHz, $\mathrm{CDCl}_{3}, \delta$ ): 7.10 (t, $\left.J=7.1 \mathrm{~Hz}, 4 \mathrm{H}\right), 7.20-7.26$ (m, 12H), 7.34 (t, $\left.J=7.7 \mathrm{~Hz}, 8 \mathrm{H}\right)$, $7.48(\mathrm{~d}, J=8.7 \mathrm{~Hz}, 4 \mathrm{H}), 7.84$ (t, $J=7.9 \mathrm{~Hz}, 2 \mathrm{H}), 8.47$ (s, 2H), 8.49 (d, $J=7.9 \mathrm{~Hz}, 2 \mathrm{H}), 8.76$ (d, $J=$ $6.3 \mathrm{~Hz}, 2 \mathrm{H}) .{ }^{13} \mathrm{C} \mathrm{NMR}\left(100 \mathrm{MHz}, \mathrm{CDCl}_{3}, \delta\right): 123.1(\mathrm{CH}), 123.7(\mathrm{CH}), 125.1(\mathrm{CH}), 125.2(\mathrm{CH}), 127.2$ (C), $128.5(C), 128.8(\mathrm{CH}), 129.6(\mathrm{CH}), 130.0(\mathrm{C}), 130.9(\mathrm{CH}), 131.3(\mathrm{CH}), 132.9(\mathrm{C}), 133.4(C)$, $134.3(\mathrm{CH}), 143.1(\mathrm{C}), 147.8(\mathrm{C}), 148.4(\mathrm{C}), 183.6(\mathrm{C}) .{ }^{13} \mathrm{C}$ NMR peaks were relatively weak because of the low solubility of $\mathbf{3 j}$. HRMS-ESI $(\mathrm{m} / \mathrm{z})$ : $[\mathrm{M}+\mathrm{Na}]^{+}$calcd for $\mathrm{C}_{58} \mathrm{H}_{36} \mathrm{O}_{2} \mathrm{~N}_{2} \mathrm{Na}, 815.2669$; found, 815.2685. $\mathrm{mp}>400{ }^{\circ} \mathrm{C}$.

\section{(E)-6,6'-Bis(3,5-di-tert-butylphenyl)-4,4'-dimethyl-3H,3'H-[2,2'-bibenzo[b]thiophenylidene]-} 3,3'-dione (3k).<smiles>Cc1cc(-c2cc(C(C)(C)C)cc(C(C)(C)C)c2)cc([N+](=O)[O-])c1C</smiles>

The reaction was performed according to the general procedure $\mathrm{B}$. The reaction was carried out with $59.0 \mathrm{mg}(0.15 \mathrm{mmol})$ of $\mathbf{1 g}$ and $84.3 \mathrm{mg}(0.36 \mathrm{mmol})$ of $\mathbf{2} \mathbf{f}$. The product $\mathbf{3} \mathbf{k}$ was obtained as a red powder $(50.0 \mathrm{mg}, 0.071 \mathrm{mmol}, 48 \%$ yield) after purification by silica-gel column chromatography $\left(\mathrm{SiO}_{2}, \mathrm{CH}_{2} \mathrm{Cl}_{2} /\right.$ hexane, 0:100-30:70).

${ }^{1} \mathrm{H}$ NMR (396 MHz, $\mathrm{CDCl}_{3}, \delta$ ): 1.41 (s, 36H), 2.84 (s, 6H), 7.27 (s, 2H), 7.45 (s, 2H), 7.46 (s, 2H), $7.52(\mathrm{t}, J=1.8 \mathrm{~Hz}, 2 \mathrm{H}), 7.54(\mathrm{~s}, 2 \mathrm{H}) .{ }^{13} \mathrm{C} \mathrm{NMR}\left(100 \mathrm{MHz}, \mathrm{CDCl}_{3}, \delta\right): 19.4\left(\mathrm{CH}_{3}\right), 31.7\left(\mathrm{CH}_{3}\right), 35.2$ 
(C), $120.8(\mathrm{CH}), 122.0(\mathrm{CH}), 123.2(\mathrm{CH}), 125.5(C), 128.1(\mathrm{CH}), 133.2(C), 139.0(C), 142.4(C)$, $149.6(C), 150.1(C), 151.7(C), 190.7(C)$. HRMS-ESI $(m / z):[\mathrm{M}+\mathrm{Na}]^{+}$calcd for $\mathrm{C}_{46} \mathrm{H}_{52} \mathrm{O}_{2} \mathrm{NaS}_{2}$, 723.3301; found, $723.3318 . \mathrm{mp}>400{ }^{\circ} \mathrm{C}$.

(E)-6,6'-Bis[4-(diphenylamino)phenyl]-4,4'-dimethyl-3H,3'H-[2,2'-bibenzo[b]thiophenylidene]3,3'-dione (3I).

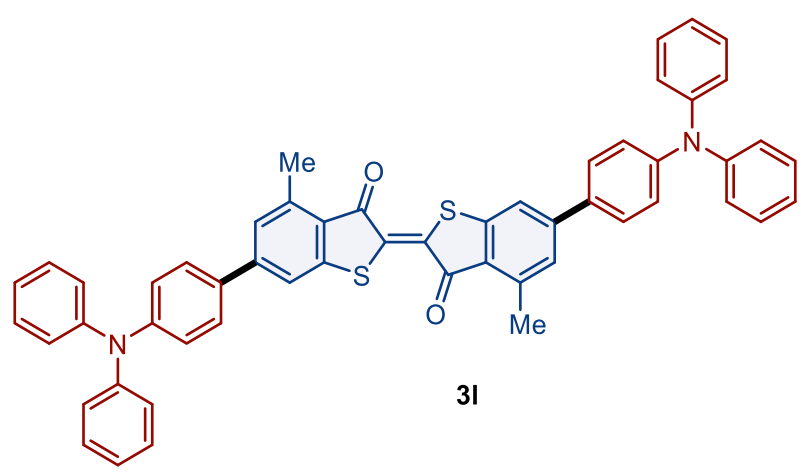

The reaction was performed according to the general procedure $\mathrm{B}$. The reaction was carried out with $59.0 \mathrm{mg}(0.15 \mathrm{mmol})$ of $\mathbf{1 g}$ and $104.1 \mathrm{mg}(0.36 \mathrm{mmol})$ of $\mathbf{2 c}$. The product $\mathbf{3 l}$ was obtained as a red powder (107.6 mg, $0.133 \mathrm{mmol}, 88 \%$ yield) after purification by silica-gel column chromatography $\left(\mathrm{SiO}_{2}, \mathrm{CH}_{2} \mathrm{Cl}_{2} /\right.$ hexane, 0:100-100:0).

${ }^{1} \mathrm{H}$ NMR (400 MHz, $\mathrm{CDCl}_{3}, \delta$ ): 2.80 (s, 6H), 7.09 (t, $\left.J=7.4 \mathrm{~Hz}, 4 \mathrm{H}\right), 7.12-7.18$ (m, 12H), 7.24-7.26 (m, 2H), 7.30 (t, $J=7.8 \mathrm{~Hz}, 8 \mathrm{H}), 7.50-7.56(\mathrm{~m}, 6 \mathrm{H}) .{ }^{13} \mathrm{C} \mathrm{NMR}\left(100 \mathrm{MHz}, \mathrm{CDCl}_{3}, \delta\right): 19.5\left(\mathrm{CH}_{3}\right)$, $119.6(\mathrm{CH}), 123.0(\mathrm{CH}), 123.8(\mathrm{CH}), 125.2(\mathrm{CH}), 127.0(\mathrm{CH}), 128.3(\mathrm{CH}), 129.6(\mathrm{CH}), 132.3(\mathrm{C})$, $133.2(C), 142.5(C), 147.4(C), 147.6(C), 149.0(C), 150.3$ (C), $190.6(C) .{ }^{13} \mathrm{C}$ NMR peaks were relatively weak because of the low solubility of 31. HRMS-ESI $(\mathrm{m} / \mathrm{z})$ : $[\mathrm{M}+\mathrm{Na}]^{+}$calcd for $\mathrm{C}_{54} \mathrm{H}_{38} \mathrm{O}_{2} \mathrm{~N}_{2} \mathrm{NaS}_{2}$, 833.2267; found, 833.2287. $\mathrm{mp}>400{ }^{\circ} \mathrm{C}$.

(E)-6,6'-Bis[3,5-bis(trimethylsilyl)phenyl]-4,4'-dimethyl-3H,3' H-[2,2'-

bibenzo[b]thiophenylidene]-3,3'-dione (3m).<smiles></smiles>

The reaction was performed according to the general procedure $\mathrm{B}$. The reaction was carried out with $39.3 \mathrm{mg}(0.10 \mathrm{mmol})$ of $\mathbf{1 g}$ and $92.3 \mathrm{mg}(0.24 \mathrm{mmol})$ of $\mathbf{2 g}$. The product $\mathbf{3 m}$ was obtained as a red 
powder (54.7 mg, $0.071 \mathrm{mmol}, 72 \%$ yield) after purification by silica-gel column chromatography $\left(\mathrm{SiO}_{2}, \mathrm{CH}_{2} \mathrm{Cl}_{2} /\right.$ hexane, 0:100-20:80).

${ }^{1} \mathrm{H}$ NMR (400 MHz, $\mathrm{CDCl}_{3}, \delta$ ): 0.35 (s, 36H), 2.84 (s, 6H), 7.26 (s, 2H), 7.54 (s, 2H), 7.68-7.76 (m, 6H). ${ }^{13} \mathrm{C}$ NMR (100 MHz, $\left.\mathrm{CDCl}_{3}, \delta\right):-0.88\left(\mathrm{CH}_{3}\right), 19.4\left(\mathrm{CH}_{3}\right), 120.8(\mathrm{CH}), 125.6(\mathrm{C}), 128.1(\mathrm{CH})$, 133.0 (CH), 133.1 (C), 138.2 (C), 138.8 (CH), 140.7 (C), 142.4 (C), 149.1 (C), 150.2 (C), 190.7 (C). HRMS-ESI $(m / z)$ : $[\mathrm{M}+\mathrm{Na}]^{+}$calcd for $\mathrm{C}_{42} \mathrm{H}_{52} \mathrm{O}_{2} \mathrm{NaS}_{2} \mathrm{Si}_{4}$, 787.2378; found, 787.2394. mp 334-340 ${ }^{\circ} \mathrm{C}$.

\section{(E)-4,4'-Dimethyl-6,6'-bis(3,3",5,5'-tetra-tert-butyl-[1,1':3',1'-terphenyl]-5'-yl)-3H,3'H-[2,2'-} bibenzo[b]thiophenylidene]-3,3'-dione (3n).

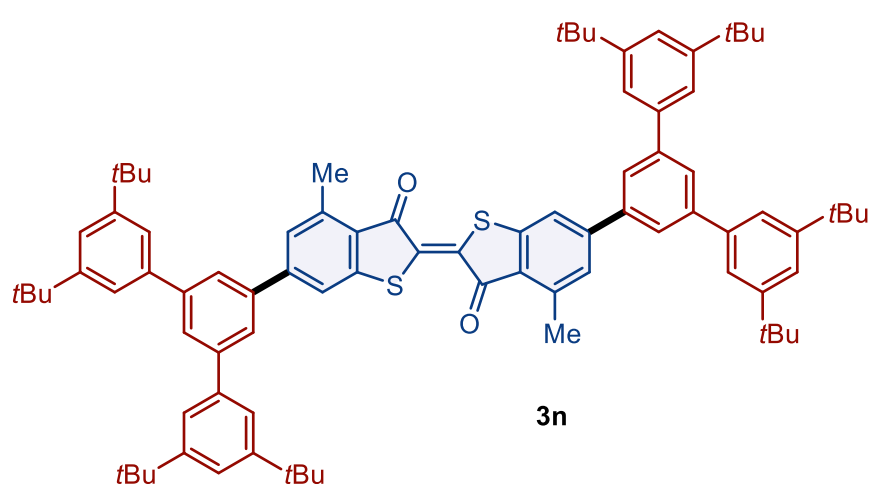

The reaction was performed according to the general procedure $\mathrm{B}$. The reaction was carried out with $39.3 \mathrm{mg}(0.10 \mathrm{mmol})$ of $\mathbf{1 g}$ and $139.4 \mathrm{mg}(0.24 \mathrm{mmol})$ of $\mathbf{2 h}$. The product $\mathbf{3 n}$ was obtained as a red powder (104.7 $\mathrm{mg}, 0.085 \mathrm{mmol}, 85 \%$ yield) after purification by silica-gel column chromatography $\left(\mathrm{SiO}_{2}, \mathrm{CH}_{2} \mathrm{Cl}_{2} /\right.$ hexane, 0:100-20:80).

${ }^{1} \mathrm{H}$ NMR $\left(396 \mathrm{MHz}, \mathrm{CDCl}_{3}, \delta\right.$ ): 1.41 (s, 72H), 2.85 (s, 6H), 7.40 (s, 2H), 7.48-7.55 (m, 12H), 7.67 (s, 2H), 7.77 (s, 3H) 7.82 (s, 3H). ${ }^{13} \mathrm{C}$ NMR (100 MHz, $\left.\mathrm{CDCl}_{3}, \delta\right): 19.4\left(\mathrm{CH}_{3}\right), 31.7\left(\mathrm{CH}_{3}\right), 35.2(\mathrm{C})$, $120.9(\mathrm{CH}), 122.2(\mathrm{CH}), 125.7(\mathrm{CH}), 125.8(\mathrm{C}), 127.8(\mathrm{CH}), 128.2(\mathrm{CH}), 133.2(\mathrm{C}), 140.4(\mathrm{C}), 140.7$ (C), $142.6(C), 144.2(C), 148.5(C), 150.3(C), 151.6(C), 190.7(C)$. HRMS-ESI $(m / z):[\mathrm{M}+\mathrm{Na}]^{+}$ calcd for $\mathrm{C}_{86} \mathrm{H}_{100} \mathrm{O}_{2} \mathrm{NaS}_{2}, 1251.7057$; found, 1251.7083. $\mathrm{mp}>400{ }^{\circ} \mathrm{C}$.

\section{5,5'"'-Bis(9,9-dioctyl-9H-fluoren-2-yl)-2,2':5',2":5",2"':5"',2'"'-quinquethiophene (3o).}

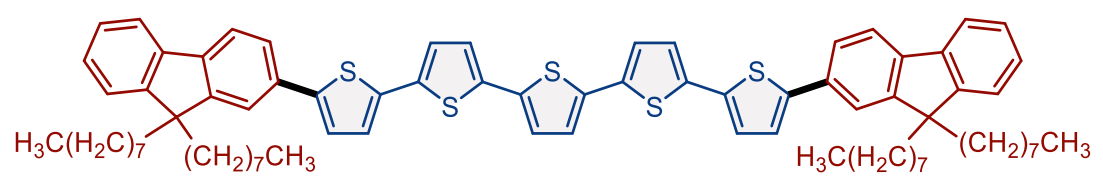

30

The reaction was performed according to the general procedure $\mathrm{B}$. The reaction was carried out with $45.6 \mathrm{mg}(0.08 \mathrm{mmol})$ of $\mathbf{1 h}$ and $99.2 \mathrm{mg}(0.19 \mathrm{mmol})$ of $\mathbf{2 e}$. The product $3 \mathbf{0}$ was obtained as an orange powder ( $48.5 \mathrm{mg}, 0.041 \mathrm{mmol}, 51 \%$ yield) after purification by silica-gel column chromatography $\left(\mathrm{SiO}_{2}, \mathrm{CH}_{2} \mathrm{Cl}_{2} /\right.$ hexane, 0:100-100:0) and GPC. 
${ }^{1} \mathrm{H}$ NMR (400 MHz, $\left.\mathrm{CDCl}_{3}, \delta\right): 0.58-0.72(\mathrm{~m}, 7 \mathrm{H}), 0.81(\mathrm{t}, J=7.2 \mathrm{~Hz}, 12 \mathrm{H}), 1.00-1.29(\mathrm{~m}, 42 \mathrm{H})$, 1.99 (t, $J=8.6 \mathrm{~Hz}, 7 \mathrm{H}), 7.12(\mathrm{~d}, J=4.8 \mathrm{~Hz}, 4 \mathrm{H}), 7.15$ (d, $J=4.4 \mathrm{~Hz}, 2 \mathrm{H}), 7.19$ (d, $J=3.6 \mathrm{~Hz}, 2 \mathrm{H})$, 7.29-7.37 (m, 8H), 7.55 (d, $J=1.6 \mathrm{~Hz}, 2 \mathrm{H}), 7.60$ (dd, $J=1.6,8.0 \mathrm{~Hz}, 2 \mathrm{H}), 7.70$ (d, $J=7.6 \mathrm{~Hz}, 4 \mathrm{H})$. ${ }^{13} \mathrm{C}$ NMR (151 MHz, $\left.\mathrm{CDCl}_{3}, \delta\right): 14.2\left(\mathrm{CH}_{3}\right), 22.7\left(\mathrm{CH}_{2}\right), 23.9\left(\mathrm{CH}_{2}\right), 29.3\left(\mathrm{CH}_{2}\right), 29.4\left(\mathrm{CH}_{2}\right), 30.1$ $\left(\mathrm{CH}_{2}\right), 31.9\left(\mathrm{CH}_{2}\right), 40.5\left(\mathrm{CH}_{2}\right), 55.3(\mathrm{C}), 119.9(\mathrm{CH}), 120.3(\mathrm{CH}), 123.0(\mathrm{CH}), 123.8(\mathrm{CH}), 124.3(\mathrm{CH})$, $124.5(\mathrm{CH}), 124.6(\mathrm{CH}), 124.7(\mathrm{CH}), 124.8(\mathrm{CH}), 127.0(\mathrm{CH}), 127.3(\mathrm{CH}), 132.8(\mathrm{C}), 135.8(C), 136.0$ (C), $136.1(C), 136.7(C), 140.7(C), 141.1(C), 144.3$ (C), $151.0(C), 151.7$ (C). HRMS-ESI $(\mathrm{m} / \mathrm{z})$ : $[\mathrm{M}]^{+}$calcd for $\mathrm{C}_{78} \mathrm{H}_{92} \mathrm{~S}_{5}, 1188.5797$; found, $1188.5810 . \mathrm{mp}>400{ }^{\circ} \mathrm{C}$.

\section{4,4'-([2,2':5',2":5",2"':5'",2"'"-Quinquethiophene]-5,5"'"-diyl)bis( $N, N$-diphenylaniline) (3p).}

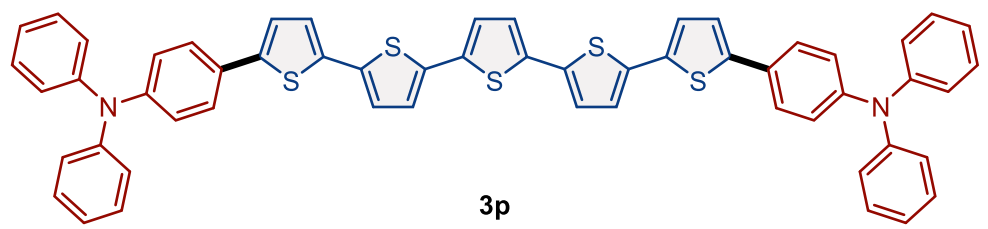

The reaction was performed according to the general procedure $\mathrm{B}$. The reaction was carried out with $34.2 \mathrm{mg}(0.06 \mathrm{mmol})$ of $\mathbf{1 h}$ and $41.6 \mathrm{mg}(0.14 \mathrm{mmol})$ of $\mathbf{2}$. The product $\mathbf{3 p}$ was obtained as a yellow powder (24.4 mg, $0.027 \mathrm{mmol}, 45 \%$ yield) after purification by silica-gel column chromatography $\left(\mathrm{SiO}_{2}, \mathrm{CH}_{2} \mathrm{Cl}_{2} /\right.$ hexane, 0:100-40:60).

${ }^{1} \mathrm{H}$ NMR (400 MHz, $\left.\mathrm{CDCl}_{3}, \delta\right): 7.02-7.10(\mathrm{~m}, 16 \mathrm{H}), 7.11-7.17$ (m, 12H), 7.28-7.31 (m, 6H), 7.46 (d, $J=8.8 \mathrm{~Hz}, 4 \mathrm{H}) .{ }^{13} \mathrm{C} \mathrm{NMR}\left(100 \mathrm{MHz}, \mathrm{CDCl}_{3}, \delta\right): 123.2(\mathrm{CH}), 123.4(\mathrm{CH}), 123.8(\mathrm{CH}), 124.0(\mathrm{CH})$, $124.3(\mathrm{CH}), 124.5(\mathrm{CH}), 124.9(\mathrm{CH}), 126.7(\mathrm{CH}), 128.2(\mathrm{C}), 129.2(\mathrm{C}), 129.5(\mathrm{CH}), 135.7(\mathrm{C}), 135.9$ (C), $136.3(C), 136.9(C), 143.7$ (C), 147.7 (C). ${ }^{13} \mathrm{C}$ NMR peaks were relatively weak because of the low solubility of 3p. HRMS-ESI $(\mathrm{m} / \mathrm{z})$ : $[\mathrm{M}]^{+}$calcd for $\mathrm{C}_{56} \mathrm{H}_{38} \mathrm{~N}_{2} \mathrm{~S}_{5}, 898.1633$; found, 898.1642. mp $>400{ }^{\circ} \mathrm{C}$. 


\section{2,9-Bis(3',5'-di-tert-butyl-[1,1'-biphenyl]-4-yl)anthra[2,1,9-def:6,5,10-d'e'f']diisoquinoline-}

\section{$1,3,8,10(2 \mathrm{H}, 9 \mathrm{H})$-tetraone $(3 q)$.}

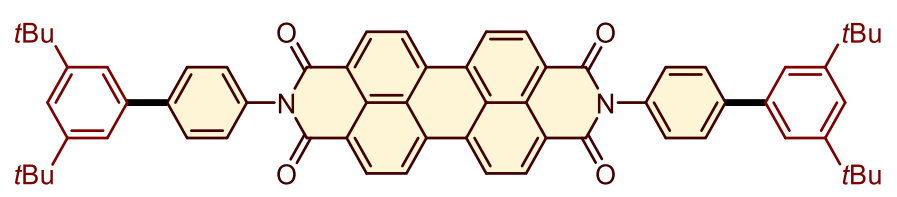

$3 q$

The reaction was performed according to the general procedure $\mathrm{B}$. The reaction was carried out with $70.0 \mathrm{mg}(0.10 \mathrm{mmol})$ of $\mathbf{1 i}$ and $56.2 \mathrm{mg}(0.24 \mathrm{mmol})$ of $\mathbf{2} \mathbf{f}$. The product $\mathbf{3 q}$ was obtained as a red powder (33.6 mg, $0.037 \mathrm{mmol}, 37 \%$ yield) after purification by silica-gel column chromatography $\left(\mathrm{SiO}_{2}, \mathrm{CH}_{2} \mathrm{Cl}_{2} /\right.$ hexane, 50:50-0:100).

${ }^{1} \mathrm{H} \mathrm{NMR}\left(400 \mathrm{MHz}, \mathrm{CDCl}_{3}, \delta\right): 1.41$ (s, 36H), 7.46 (d, $\left.J=6.4 \mathrm{~Hz}, 4 \mathrm{H}\right), 7.49-7.51$ (m, 6H), 7.78 (d, $J$ $=8.4 \mathrm{~Hz}, 4 \mathrm{H}), 8.67(\mathrm{~d}, J=8.0 \mathrm{~Hz}, 4 \mathrm{H}), 8.78(\mathrm{~d}, J=7.6 \mathrm{~Hz}, 4 \mathrm{H}) .{ }^{13} \mathrm{C} \mathrm{NMR}\left(100 \mathrm{MHz}, \mathrm{CDCl}_{3}, \delta\right): 31.7$ $\left(\mathrm{CH}_{3}\right), 35.1(\mathrm{C}), 121.8(\mathrm{CH}), 122.1(\mathrm{CH}), 123.2(\mathrm{CH}), 123.5(\mathrm{C}), 126.1(\mathrm{C}), 128.8(\mathrm{CH}), 128.9(\mathrm{CH})$, 129.3 (C), 131.5 (CH), 133.8 (C), 134.4 (C), 140.1 (C), 143.4 (C), 151.3 (C), $163.4(C) .{ }^{13} \mathrm{C}$ NMR peaks were relatively weak because of the low solubility of 3q. HRMS-ESI $(\mathrm{m} / \mathrm{z})$ : $[\mathrm{M}+\mathrm{Na}]^{+}$calcd for $\mathrm{C}_{64} \mathrm{H}_{58} \mathrm{O}_{4} \mathrm{~N}_{2} \mathrm{Na}$, 914.4289; found, 914.4315. $\mathrm{mp}>400{ }^{\circ} \mathrm{C}$.

(E)-6,6'-Bis(3,5-di-tert-butylphenyl)-[3,3'-biindolinylidene]-2,2'-dione (3r).<smiles>CC(C)(C)c1cc(-c2ccc3c(c2)NC(=O)C3=C2C(=O)Nc3cc(-c4cc(C(C)(C)C)cc(C(C)(C)C)c4)ccc32)cc(C(C)(C)C)c1</smiles>

The reaction was performed according to the general procedure $\mathrm{B}$. The reaction was carried out with $63.0 \mathrm{mg}(0.15 \mathrm{mmol})$ of $\mathbf{1} \mathbf{j}$ and $84.3 \mathrm{mg}(0.36 \mathrm{mmol})$ of $\mathbf{2} \mathbf{f}$. The product $\mathbf{3 r}$ was obtained as a red powder (38.3 mg, $0.060 \mathrm{mmol}, 40 \%$ yield) after purification by silica-gel column chromatography $\left(\mathrm{SiO}_{2}, \mathrm{CH}_{2} \mathrm{Cl}_{2} /\right.$ hexane, 50:50-0:100).

${ }^{1} \mathrm{H} \mathrm{NMR}\left(396 \mathrm{MHz}, \mathrm{CDCl}_{3}, \delta\right.$ ): 1.39 (s, 36H), 7.06 (d, $\left.J=1.2 \mathrm{~Hz}, 2 \mathrm{H}\right), 7.31$ (dd, $\left.J=1.8,8.1 \mathrm{~Hz}, 2 \mathrm{H}\right)$, $7.46(\mathrm{~d}, J=2.0 \mathrm{~Hz}, 2 \mathrm{H}), 7.48$ (d, $J=1.6 \mathrm{~Hz}, 4 \mathrm{H}), 7.73$ (s, 2H), 9.19 (d, $J=8.3 \mathrm{~Hz}, 2 \mathrm{H}) .{ }^{13} \mathrm{C} \mathrm{NMR}$ $\left(151 \mathrm{MHz}, \mathrm{CDCl}_{3}, \delta\right): 31.7\left(\mathrm{CH}_{3}\right), 35.2(\mathrm{C}), 108.2(\mathrm{CH}), 115.1(\mathrm{C}), 121.6(\mathrm{CH}), 122.7(\mathrm{CH}), 130.5$ $(\mathrm{CH}), 132.6(\mathrm{C}), 139.8(\mathrm{C}), 143.0(\mathrm{C}), 146.9(\mathrm{C}), 151.5(\mathrm{C}), 169.8(\mathrm{C}) .{ }^{13} \mathrm{C}$ NMR peaks were relatively weak because of the low solubility of 3r. HRMS-ESI $(m / z)$ : $[\mathrm{M}+\mathrm{Na}]^{+}$calcd for $\mathrm{C}_{44} \mathrm{H}_{50} \mathrm{O}_{2} \mathrm{~N}_{2} \mathrm{Na}$, 661.3765; found, 661.3774. $\mathrm{mp}>400{ }^{\circ} \mathrm{C}$. 


\section{4,4'-(5,15-Diethyl-5,15-dihydrocarbazolo [3',4':5,6][1,4] oxazino[2,3-b]indolo[3,2-}

h]phenoxazine-9,19-diyl)bis( $N, N$-diphenylaniline) (3s).

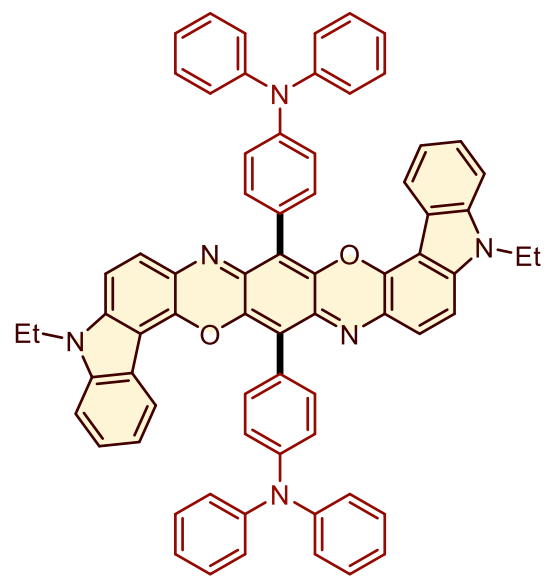

$3 s$

The reaction was performed according to the general procedure $\mathrm{B}$. The reaction was carried out with $58.8 \mathrm{mg}(0.10 \mathrm{mmol})$ of $\mathbf{1 k}$ and $69.4 \mathrm{mg}(0.24 \mathrm{mmol})$ of $\mathbf{2 c}$. The product $3 \mathbf{s}$ was obtained as a purple powder (38.9 mg, $0.039 \mathrm{mmol}, 39 \%$ yield) after purification by silica-gel column chromatography $\left(\mathrm{SiO}_{2}, \mathrm{CH}_{2} \mathrm{Cl}_{2} /\right.$ hexane, 50:50-0:100).

${ }^{1} \mathrm{H}$ NMR (400 MHz, $\left.\mathrm{C}_{2} \mathrm{D}_{2} \mathrm{Cl}_{4}, \delta\right): 1.52(\mathrm{t}, J=7.2 \mathrm{~Hz}, 6 \mathrm{H}), 4.31-4.47(\mathrm{~m}, 4 \mathrm{H}), 7.11-7.18(\mathrm{~m}, 7 \mathrm{H})$, $7.34-7.45(\mathrm{~m}, 23 \mathrm{H}), 7.45-7.54(\mathrm{~m}, 4 \mathrm{H}), 7.71(\mathrm{~d}, J=8.0 \mathrm{~Hz}, 4 \mathrm{H}), 7.95(\mathrm{~d}, J=7.2 \mathrm{~Hz}, 2 \mathrm{H}) .{ }^{13} \mathrm{C} \mathrm{NMR}$ peaks were barely detected because of the low solubility of 3s. HRMS-ESI $(\mathrm{m} / \mathrm{z})$ : $[\mathrm{M}+\mathrm{H}]^{+}$calcd for $\mathrm{C}_{70} \mathrm{H}_{51} \mathrm{O}_{2} \mathrm{~N}_{6}, 1007.4068$; found, 1007.4099. $\mathrm{mp}>400{ }^{\circ} \mathrm{C}$.

\section{5,15-Diethyl-9,19-bis[4-(2-ethylhexyl)thiophen-2-yl]-5,15-}

dihydrocarbazolo $\left[3^{\prime}, 4^{\prime}: 5,6\right][1,4]$ oxazino[2,3-b]indolo[3,2-h]phenoxazine (3t).

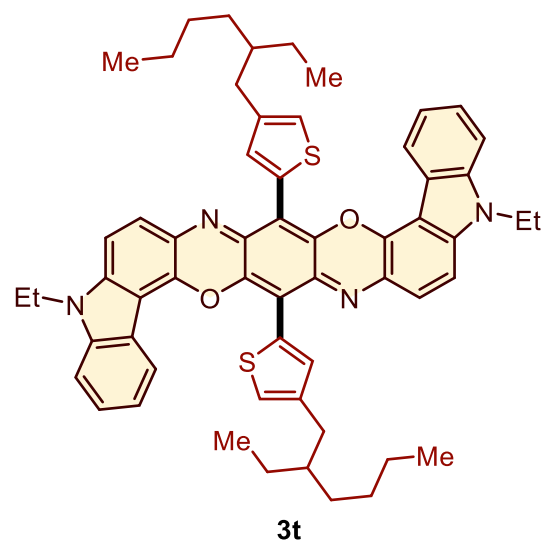

The reaction was performed according to the general procedure $\mathrm{B}$. The reaction was carried out with $58.8 \mathrm{mg}(0.10 \mathrm{mmol})$ of $1 \mathbf{k}$ and $77.4 \mathrm{mg}(0.24 \mathrm{mmol})$ of $\mathbf{2 i}$. The product $3 \mathbf{t}$ was obtained as a purple powder (10.3 mg, $0.011 \mathrm{mmol}, 11 \%$ yield) after purification by silica-gel column chromatography 
( $\mathrm{SiO}_{2}, \mathrm{CH}_{2} \mathrm{Cl}_{2} /$ hexane, 0:100-40:60).

${ }^{1} \mathrm{H}$ NMR (396 MHz, $\mathrm{CDCl}_{3}, \delta$ ): 0.98-1.00 (m, 12H), 1.18-1.50 (m, 22H), 1.69 (quint, $J=6.1 \mathrm{~Hz}, 2 \mathrm{H}$ ), $2.72-2.90(\mathrm{~m}, 4 \mathrm{H}), 4.35(\mathrm{q}, J=7.1 \mathrm{~Hz}, 4 \mathrm{H}), 7.14(\mathrm{~d}, J=8.7 \mathrm{~Hz}, 2 \mathrm{H}), 7.18(\mathrm{~d}, J=7.9 \mathrm{~Hz}, 1 \mathrm{H}), 7.22-$ 7.28 (m, 3H), 7.38 (d, $J=8.3 \mathrm{~Hz}, 2 \mathrm{H}), 7.46$ (t, $J=7.1 \mathrm{~Hz}, 2 \mathrm{H}), 7.56$ (d, $J=3.6 \mathrm{~Hz}, 2 \mathrm{H}), 7.57$ (d, $J=$ $3.6 \mathrm{~Hz}, 2 \mathrm{H}), 8.08(\mathrm{~d}, J=7.9 \mathrm{~Hz}, 2 \mathrm{H}) .{ }^{13} \mathrm{C} \mathrm{NMR}\left(100 \mathrm{MHz}, \mathrm{CDCl}_{3}, \delta\right): 11.0\left(\mathrm{CH}_{3}\right), 14.1\left(\mathrm{CH}_{3}\right), 14.3$ $\left(\mathrm{CH}_{3}\right), 23.3\left(\mathrm{CH}_{2}\right), 25.8\left(\mathrm{CH}_{2}\right), 29.2\left(\mathrm{CH}_{2}\right), 32.8\left(\mathrm{CH}_{2}\right), 34.8\left(\mathrm{CH}_{2}\right), 38.0\left(\mathrm{CH}_{2}\right), 40.3(\mathrm{CH}), 105.3$ $(\mathrm{CH}), 108.7(\mathrm{CH}), 109.9(\mathrm{C}), 111.7(\mathrm{C}), 120.2(\mathrm{CH}), 121.4(\mathrm{C}), 123.1(\mathrm{CH}), 123.6(\mathrm{CH}), 125.9(\mathrm{CH})$, $126.4(\mathrm{CH}), 128.5(\mathrm{C}), 131.3(\mathrm{C}), 131.9(\mathrm{CH}), 140.1(\mathrm{C}), 140.2(\mathrm{C}), 141.0(\mathrm{C}), 141.2(\mathrm{C}), 143.6(\mathrm{C})$, $146.7(\mathrm{C}) .{ }^{13} \mathrm{C}$ NMR peaks were relatively weak because of the low solubility of 3 t. HRMS-ESI $(\mathrm{m} / \mathrm{z})$ : $[\mathrm{M}+\mathrm{H}]^{+}$calcd for $\mathrm{C}_{58} \mathrm{H}_{61} \mathrm{O}_{2} \mathrm{~N}_{4} \mathrm{~S}_{2}, 909.4231$; found, 909.4246. mp $>400{ }^{\circ} \mathrm{C}$.

\section{9,19-Bis(3,5-di-tert-butylphenyl)-5,15-diethyl-5,15-dihydrocarbazolo[ $\left[3^{\prime}, 4^{\prime}: 5,6\right][1,4]$ oxazino[2,3-} b]indolo[3,2-h]phenoxazine (3u).
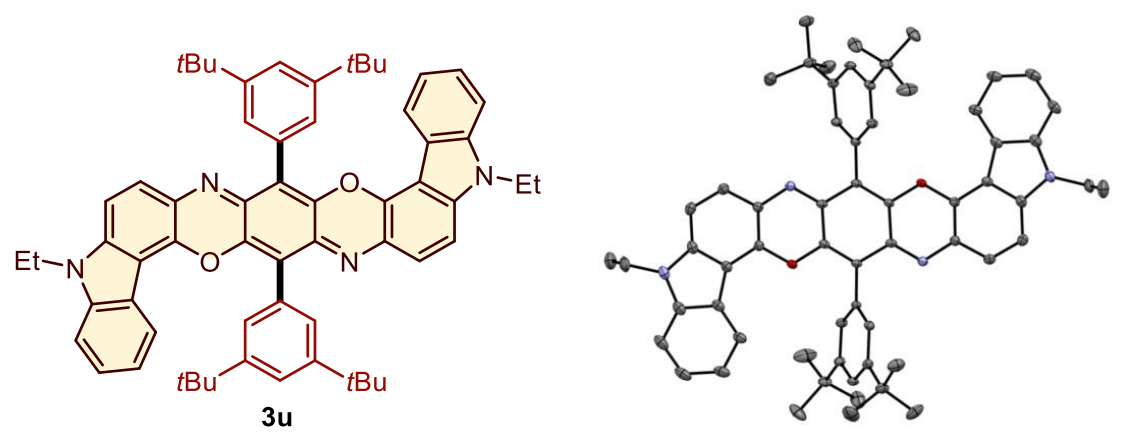

The reaction was performed according to the general procedure $\mathrm{B}$. The reaction was carried out with $58.8 \mathrm{mg}(0.10 \mathrm{mmol})$ of $\mathbf{1 k}$ and $56.2 \mathrm{mg}(0.24 \mathrm{mmol})$ of $\mathbf{2 f}$. The product $3 \mathbf{u}$ was obtained as a purple powder (26.9 $\mathrm{mg}, 0.030 \mathrm{mmol}, 30 \%$ yield) after purification by silica-gel column chromatography $\left(\mathrm{SiO}_{2}, \mathrm{CH}_{2} \mathrm{Cl}_{2} /\right.$ hexane, 0:100-40:60).

${ }^{1} \mathrm{H}$ NMR (396 MHz, $\mathrm{CDCl}_{3}, \delta$ ): 1.42 (s, 42H), 4.28 (q, J=7.1 Hz, 4H), 6.90 (t, $\left.J=6.9 \mathrm{~Hz}, 2 \mathrm{H}\right), 6.99$ $(\mathrm{d}, J=7.5 \mathrm{~Hz}, 2 \mathrm{H}), 7.02(\mathrm{~d}, J=8.7 \mathrm{~Hz}, 2 \mathrm{H}), 7.28(\mathrm{~d}, J=7.9 \mathrm{~Hz}, 2 \mathrm{H}), 7.35(\mathrm{td}, J=1.2,7.6 \mathrm{~Hz}, 2 \mathrm{H})$, 7.39 (d, $J=1.6 \mathrm{~Hz}, 4 \mathrm{H}), 7.45(\mathrm{~d}, J=8.7 \mathrm{~Hz}, 2 \mathrm{H}), 7.67(\mathrm{t}, J=1.8 \mathrm{~Hz}, 2 \mathrm{H}) .{ }^{13} \mathrm{C} \mathrm{NMR}\left(100 \mathrm{MHz}, \mathrm{CDCl}_{3}\right.$,

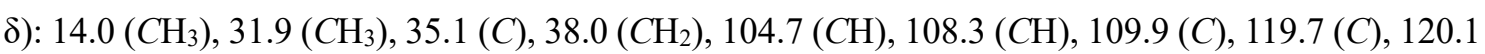
$(\mathrm{CH}), 121.5(\mathrm{C}), 121.7(\mathrm{CH}), 123.7(\mathrm{CH}), 125.1(\mathrm{CH}), 125.6(\mathrm{CH}), 126.4(\mathrm{CH}), 129.0(\mathrm{C}), 132.3(\mathrm{C})$, 140.0 (C), $140.6(C), 140.7(C), 143.9$ (C), 148.3 (C), 150.7 (C). ${ }^{13} \mathrm{C}$ NMR peaks were relatively weak because of the low solubility of $3 \mathbf{u}$. HRMS-ESI $(\mathrm{m} / \mathrm{z})$ : $[\mathrm{M}]^{+}$calcd for $\mathrm{C}_{62} \mathrm{H}_{65} \mathrm{O}_{2} \mathrm{~N}_{4}, 897.5102$; found, 897.5113. $\mathrm{mp}>400{ }^{\circ} \mathrm{C}$. 


\section{References.}

1. Sheldrick, G. M. Crystal structure refinement with SHELXL. Acta Cryst. Sect. C, 71, 3-8 (2015).

2. Seo, T., Ishiyama, T., Kubota, K. \& Ito, H. Solid-state Suzuki-Miyaura cross-coupling reactions: Olefin-accelerated C-C coupling using mechanochemistry. Chem. Sci. 10, 8202-8210 (2019).

3. Báti, G., Csókás, D., Yong, T., Tam, S. M., Shi, R. S. S., Webster, R. D., Pápai, I., García, F. \& Stuparu, M. C. Mechanochemical Synthesis of Corannulene-Based Curved Nanographenes. Angew. Chem. Int. Ed. 59, 21620-21626 (2020).

4. Scrivens, W. A. \& Tour, J. M. Potent solvents for C60 and their utility for the rapid acquisition of 13C NMR data for fullerenes. J. Chem. Soc. Chem. Commun. 3, 1207-1209 (1993).

5. Li, Z. H., Wong, M. S. \& Tao, Y. Two-dimensional oligoarylenes: Synthesis and structureproperties relationships. Tetrahedron 61, 5277-5285 (2005).

6. Liu, S., Zhang, H., Li, Y., Liu, J., Du, L., Chen, M., Kwok, R. T. K., Lam, J. W. Y., Phillips, D. L. \& Tang, B. Z. Strategies to Enhance the Photosensitization: Polymerization and the DonorAcceptor Even-Odd Effect. Angew. Chem. Int. Ed. 57, 15189-15193 (2018).

7. Holzer, B., Bintinger, J., Lumpi, D., Choi, C., Kim, Y., Stöger, B., Hametner, C., MarchettiDeschmann, M., Plasser, F., Horkel, E., Kymissis, I., Fróhlich J. Color Fine-Tuning of Optical Materials Through Rational Design. ChemPhysChem 18, 549-563 (2017). 


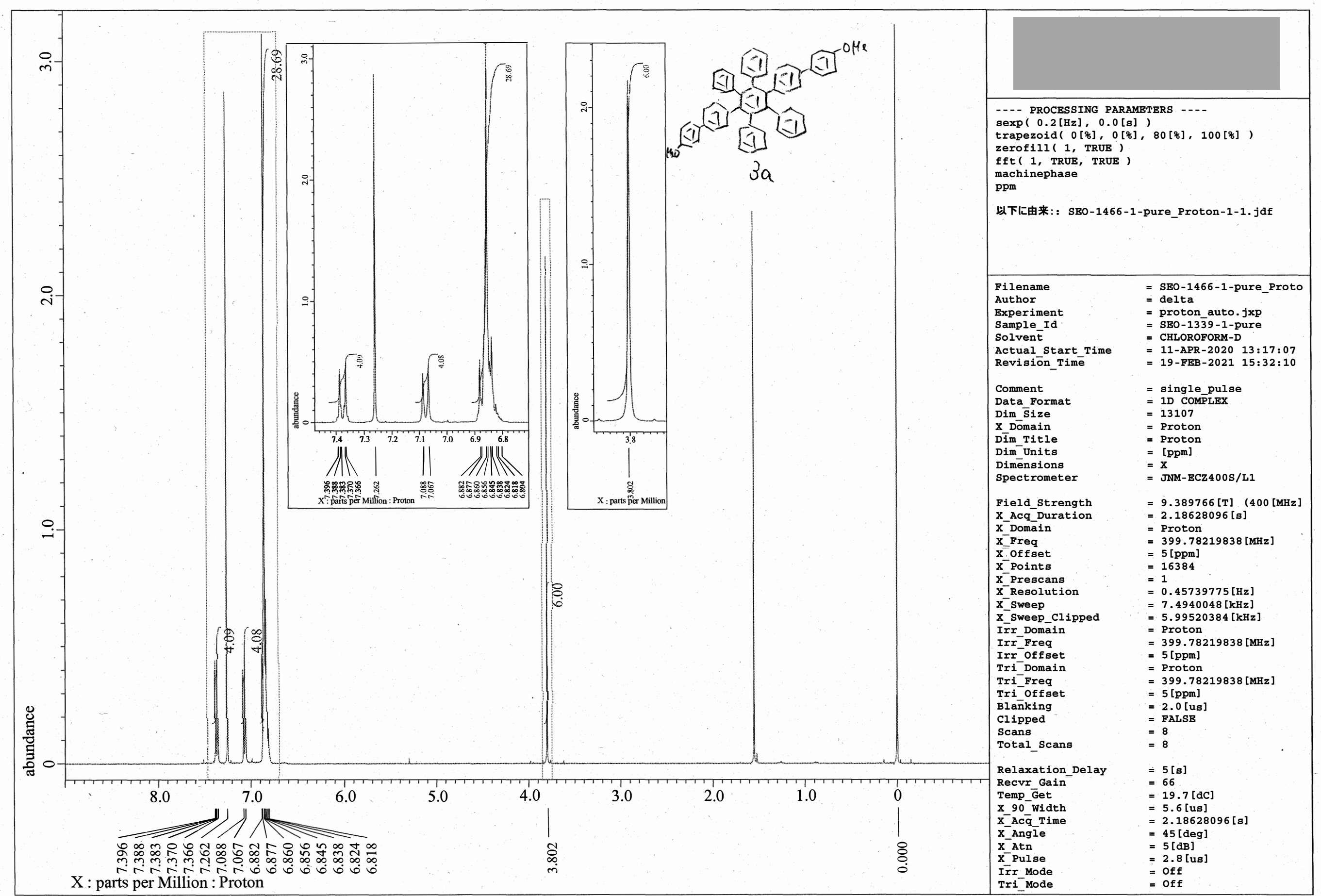




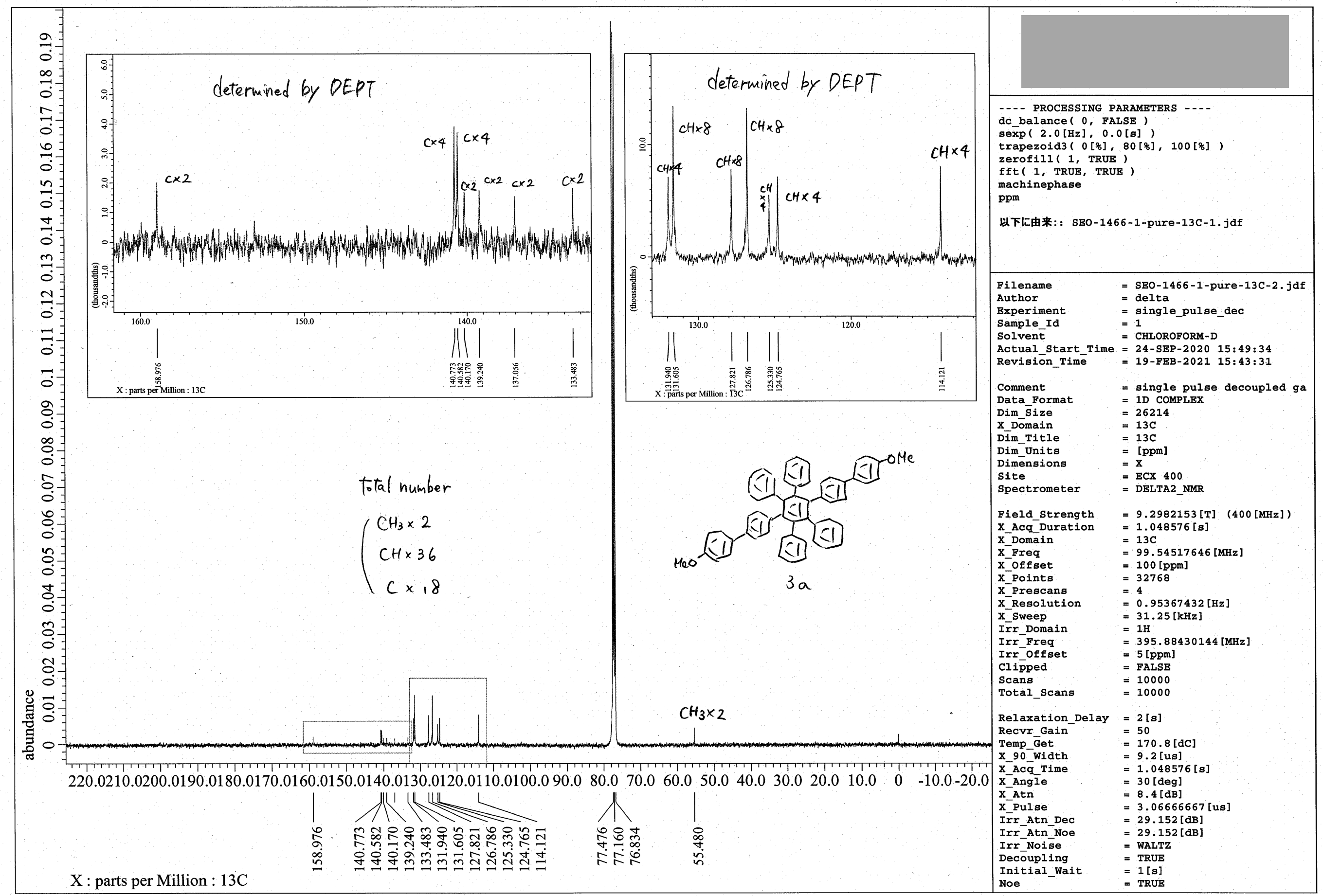




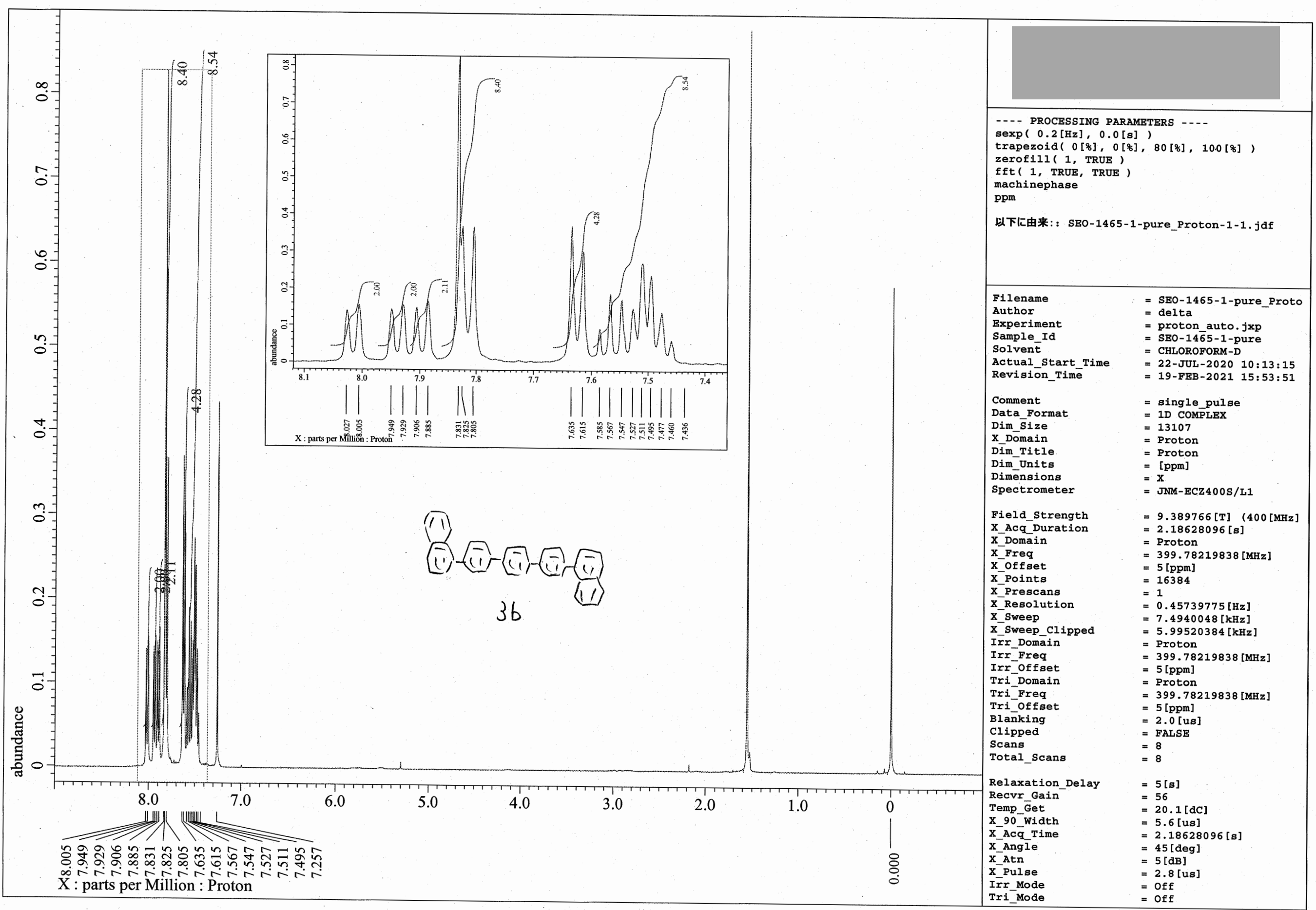




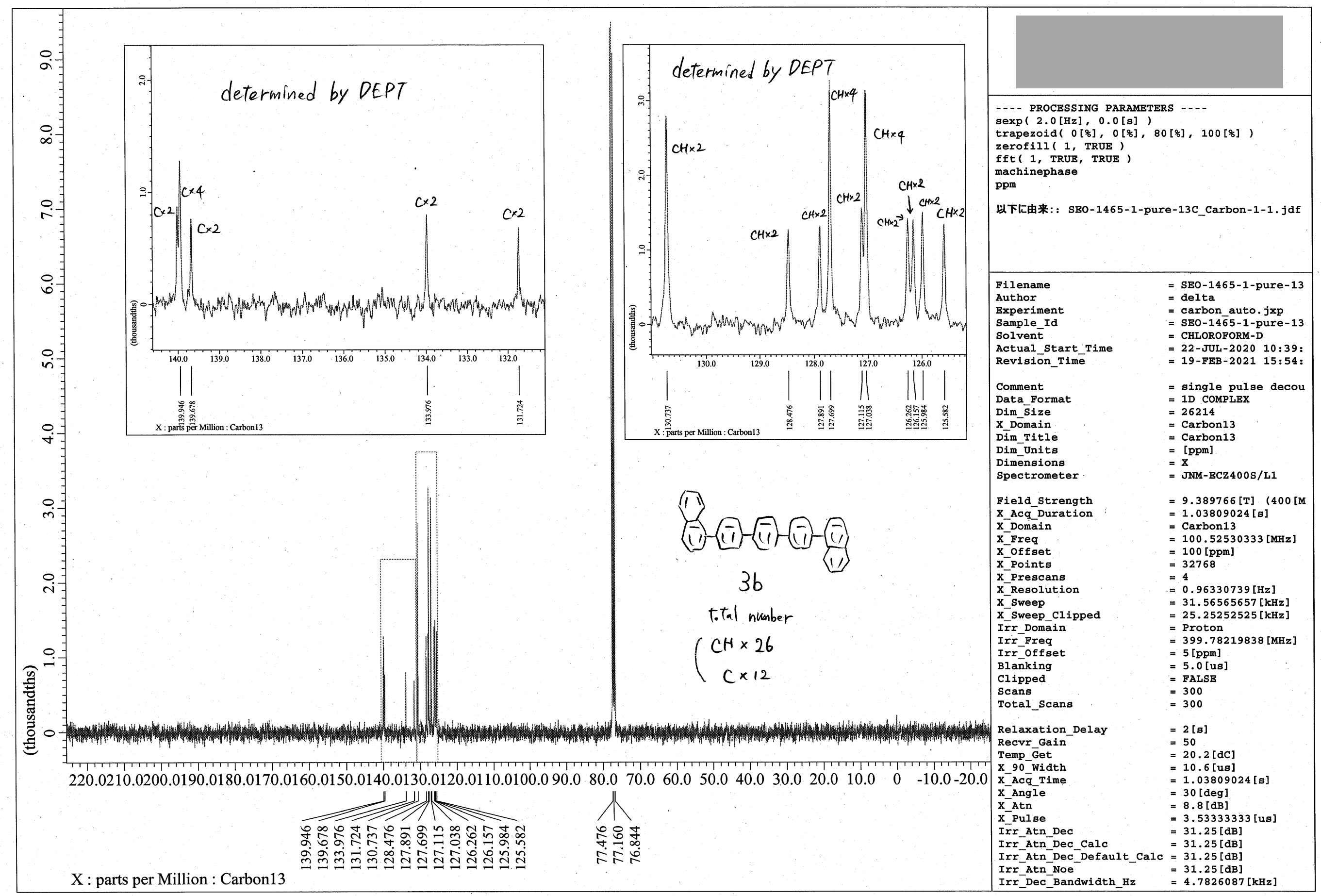




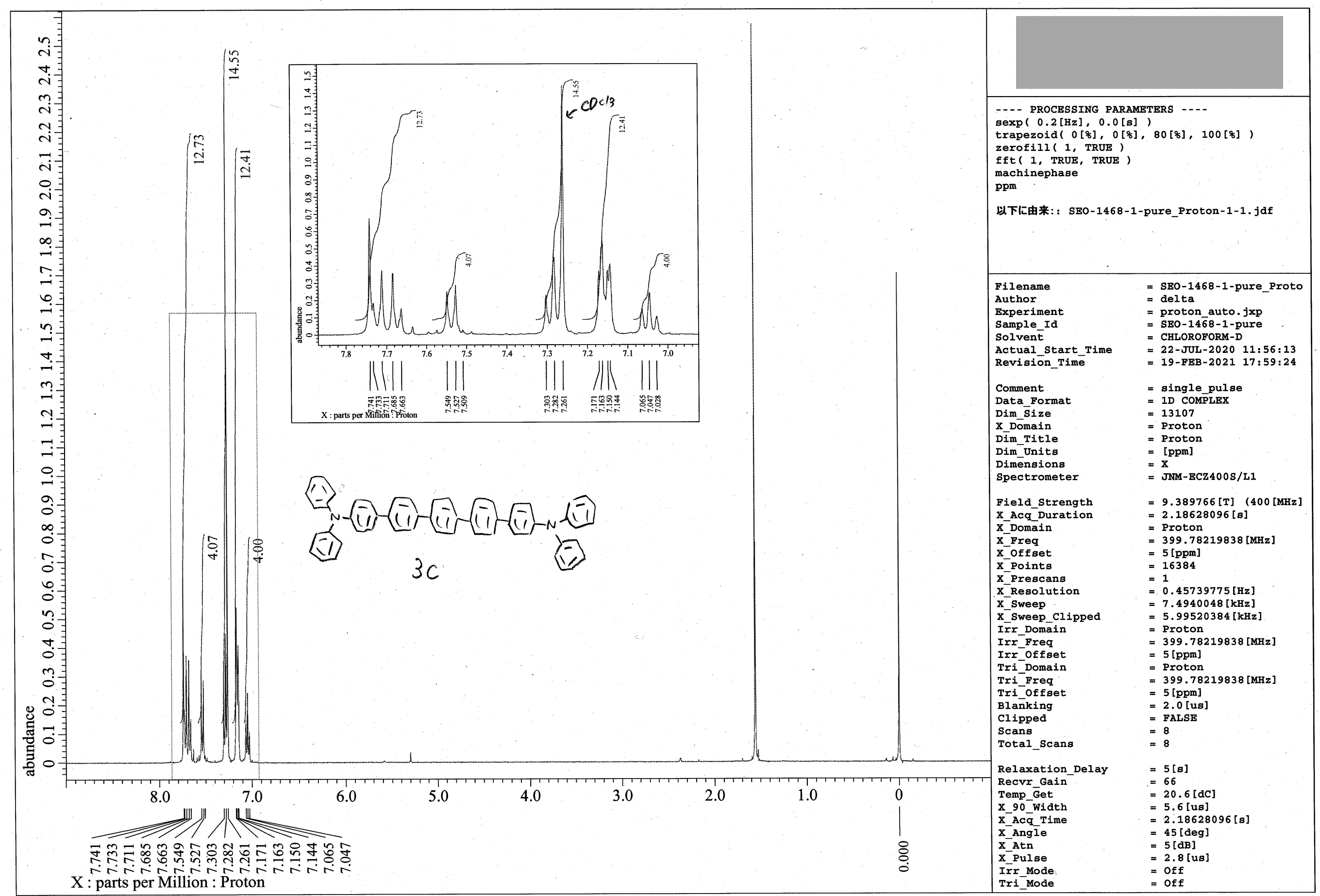




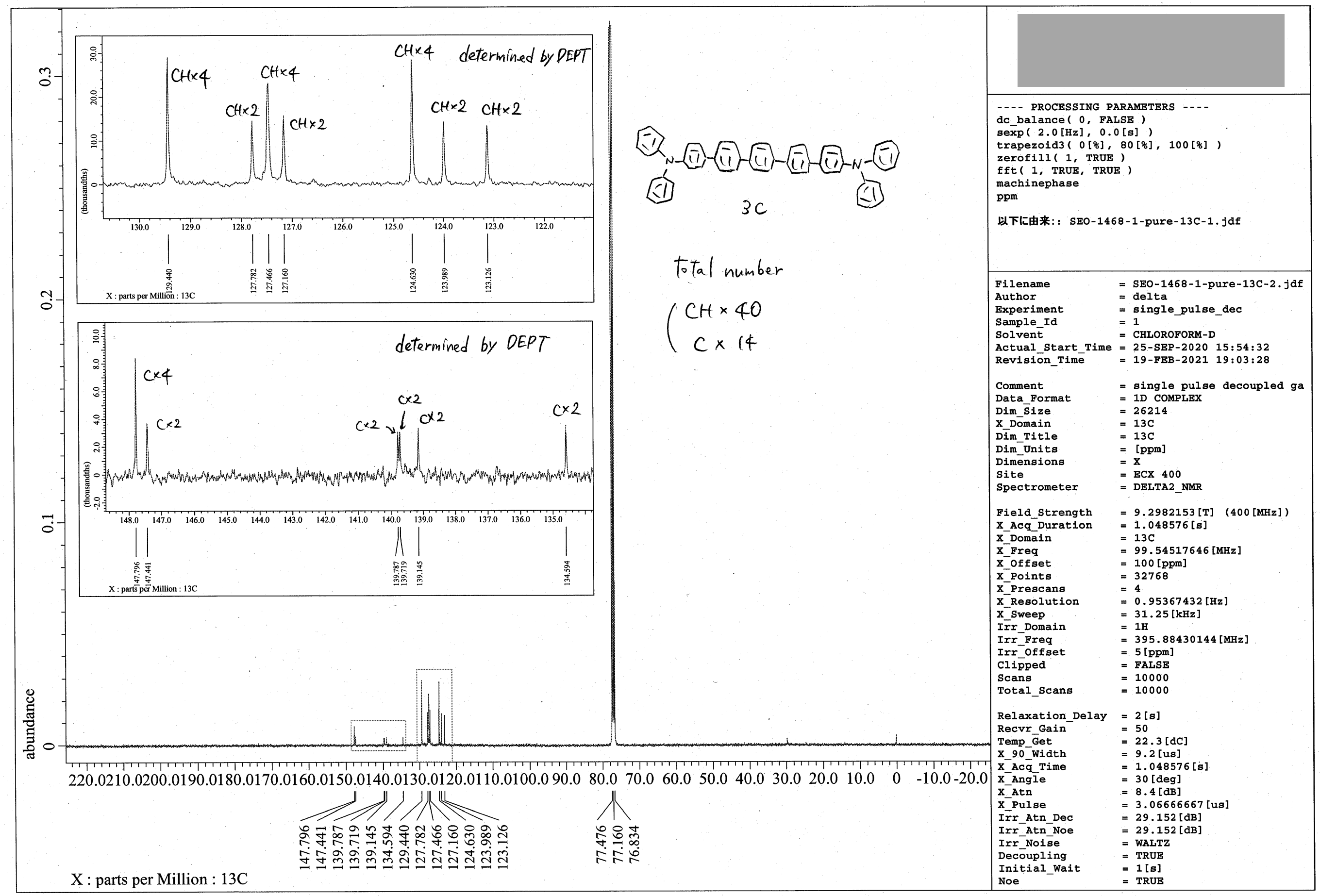




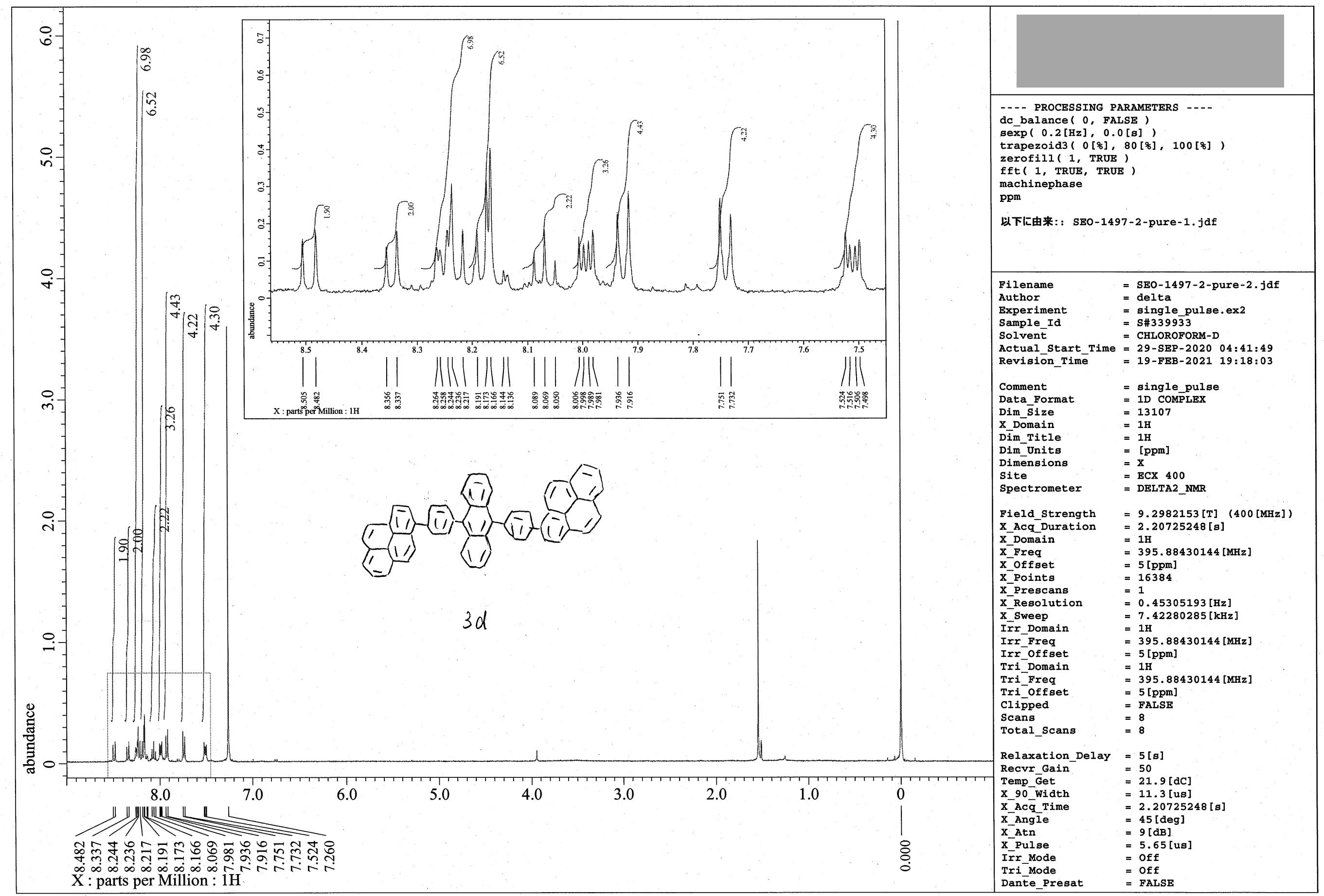




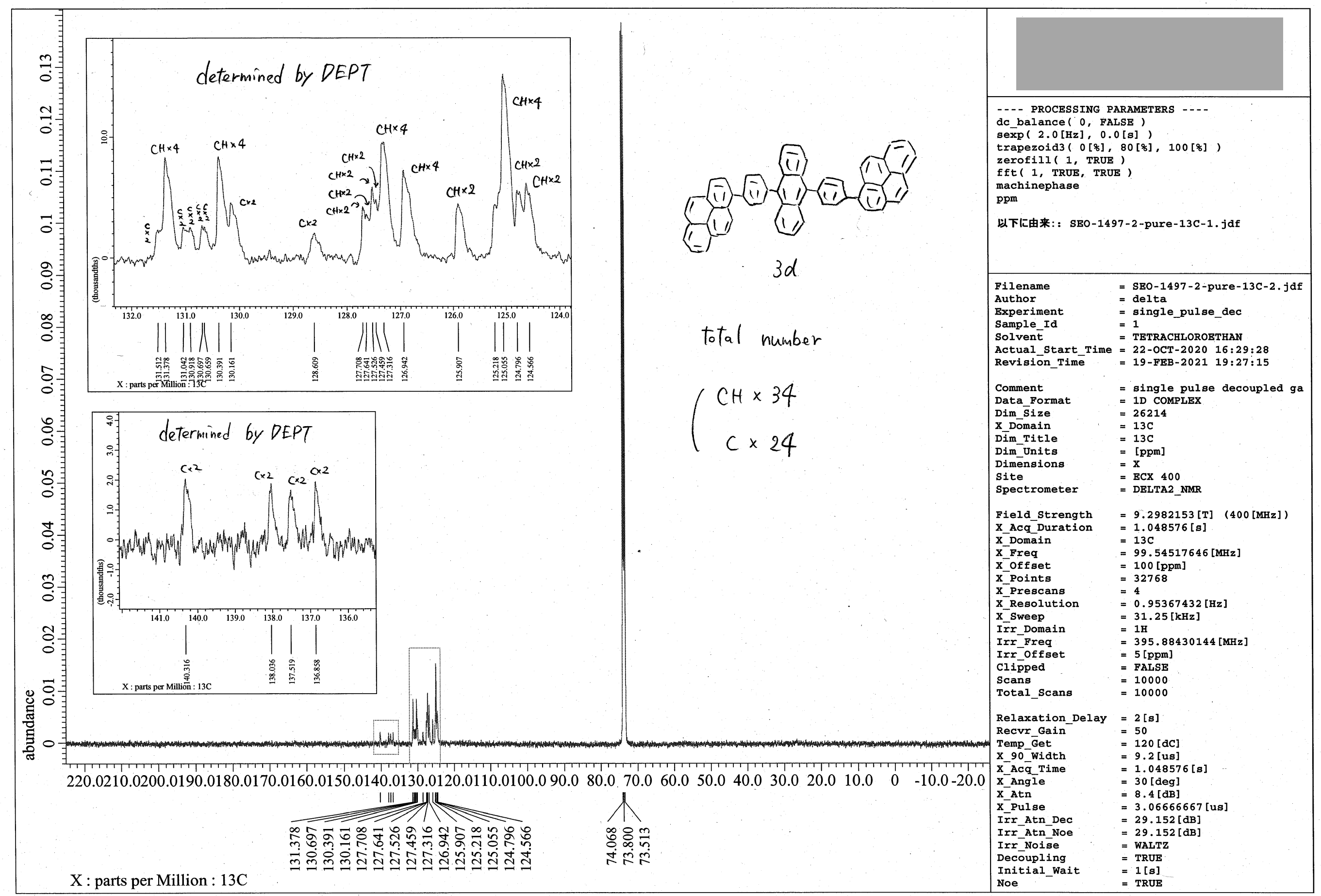




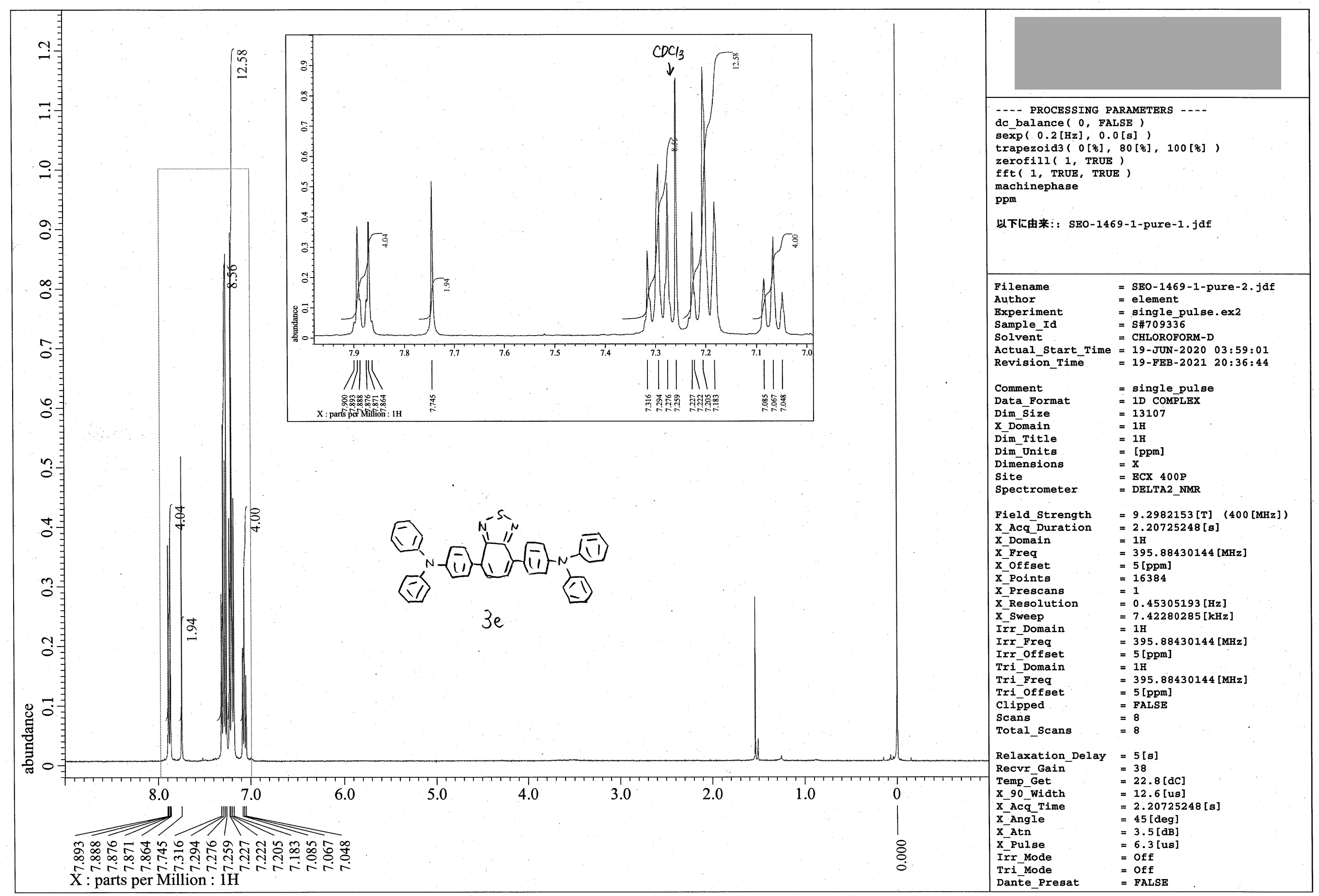




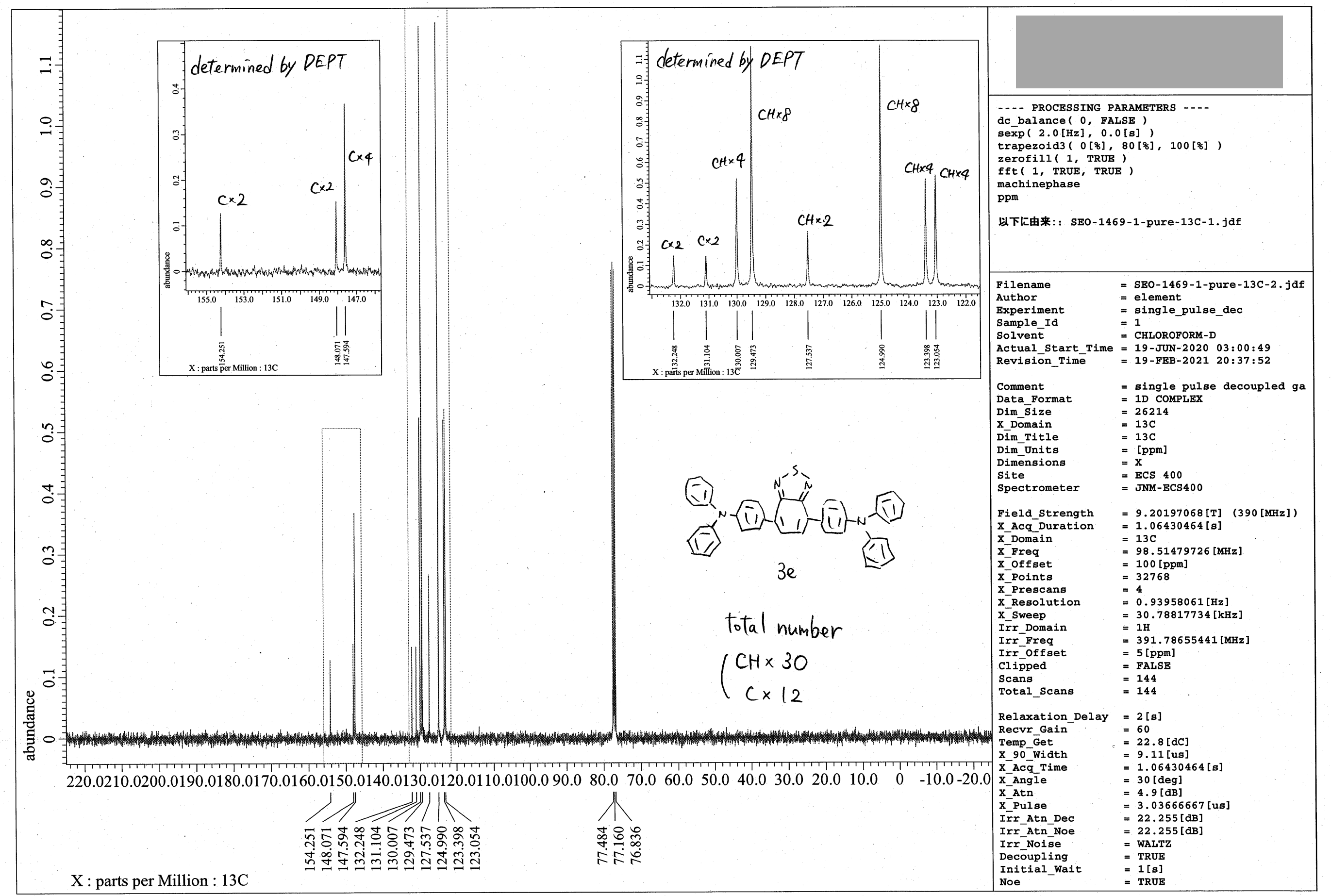




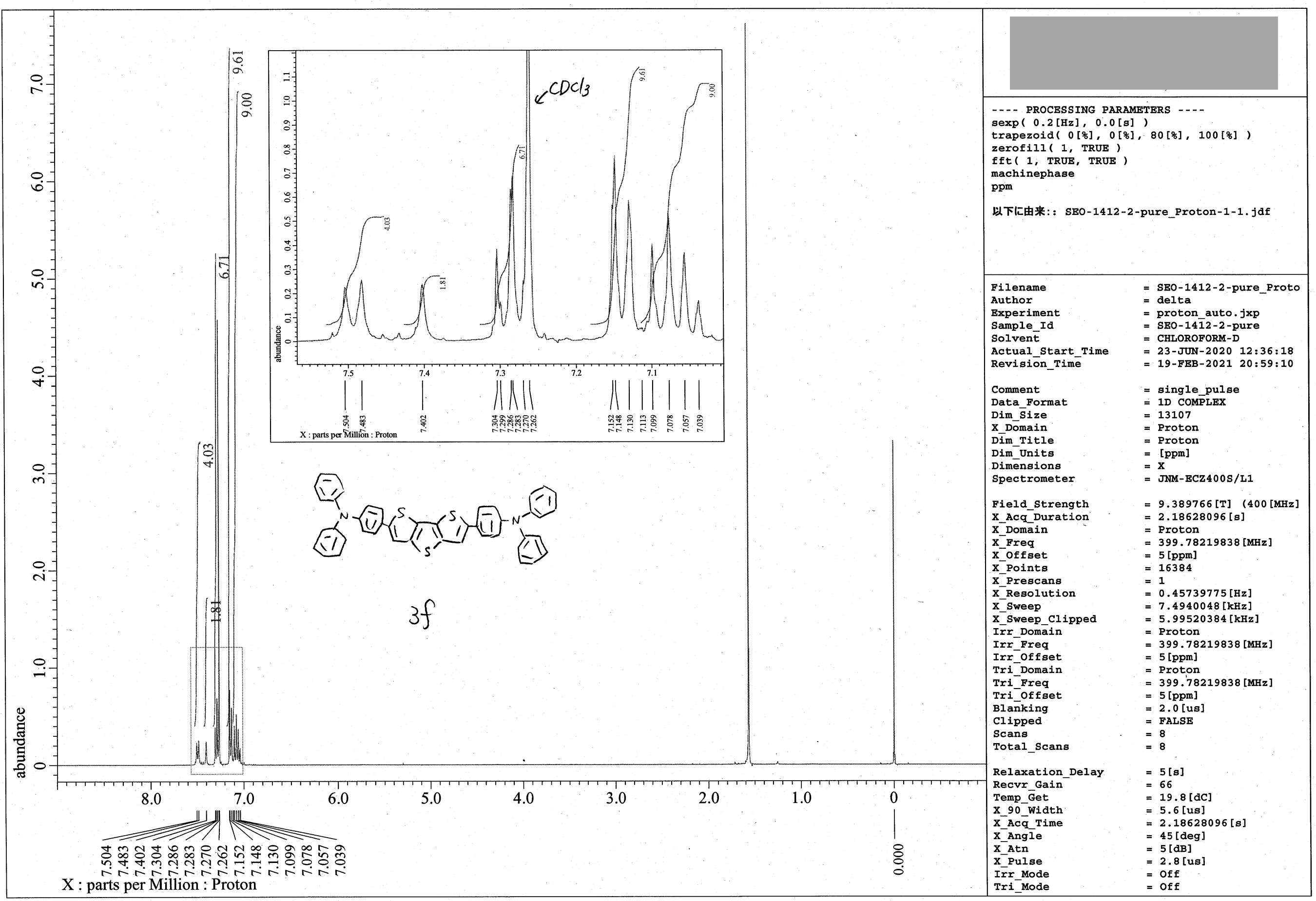




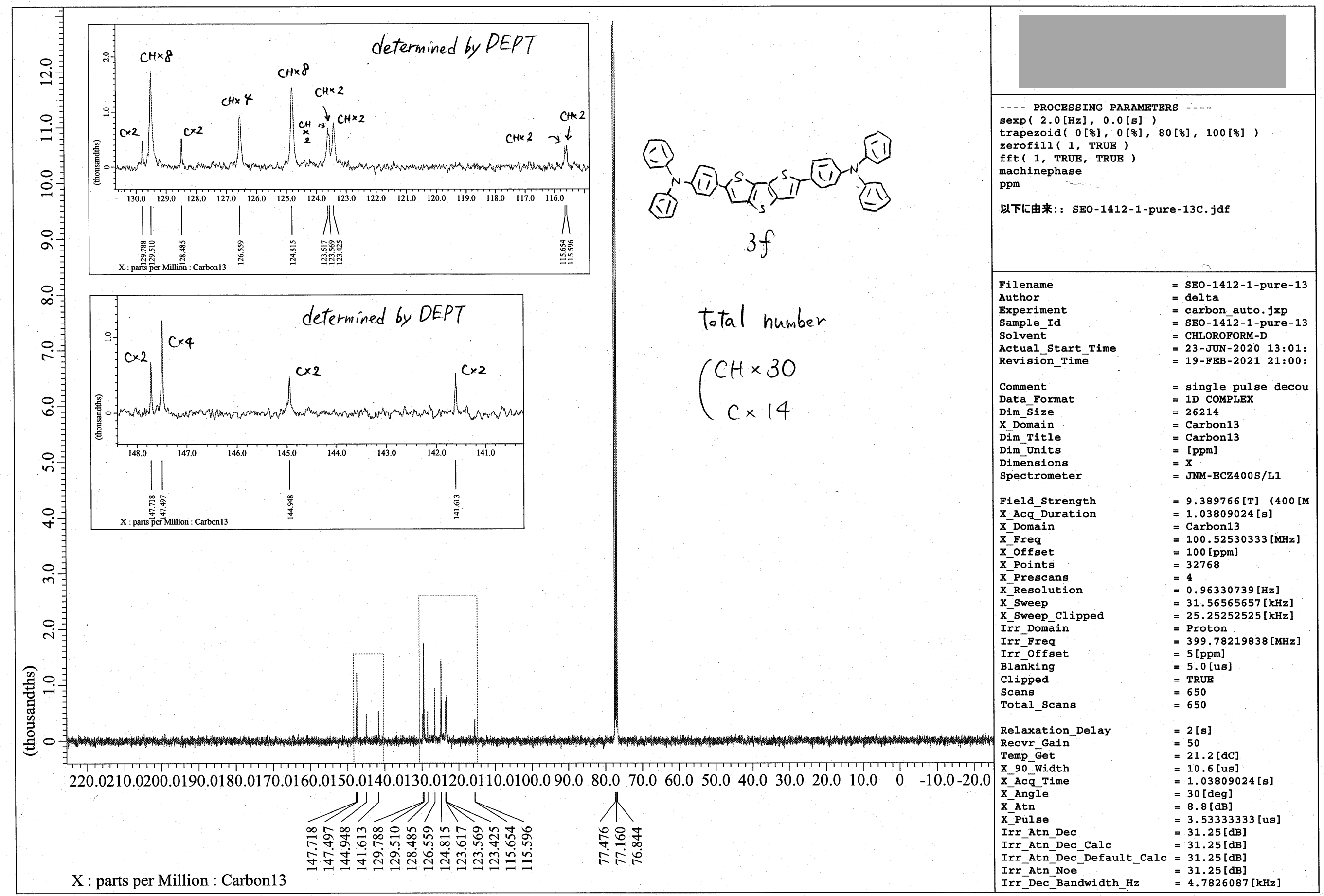




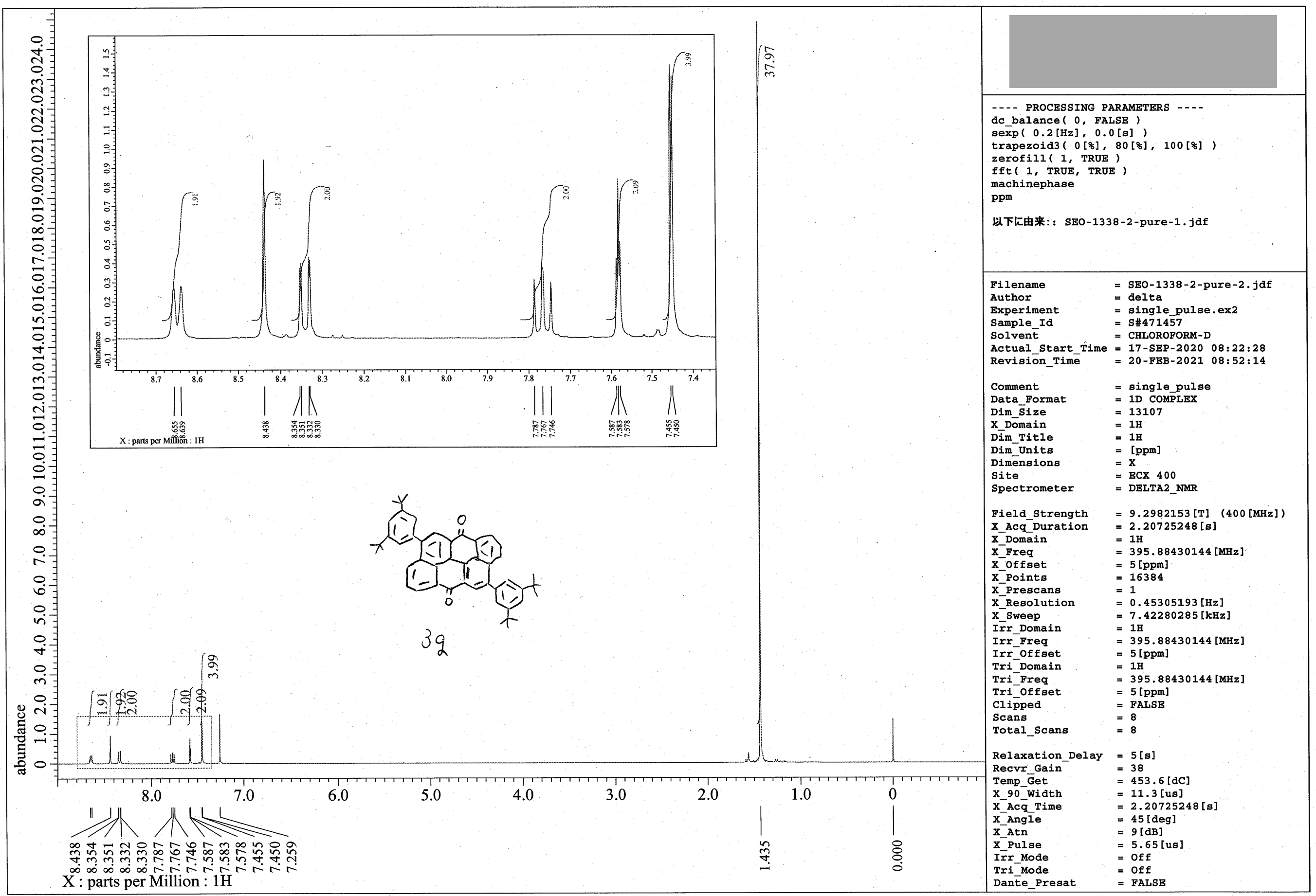




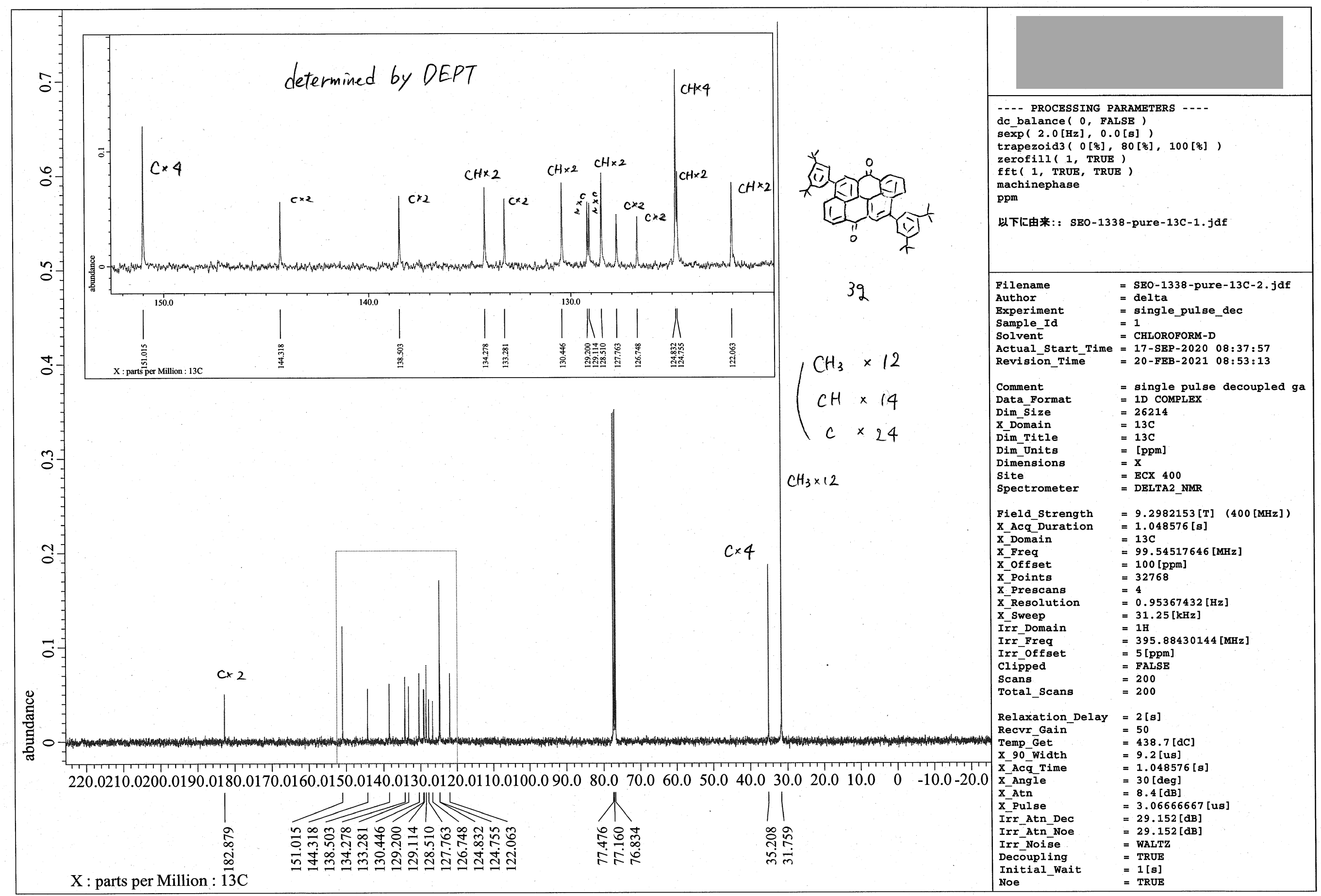




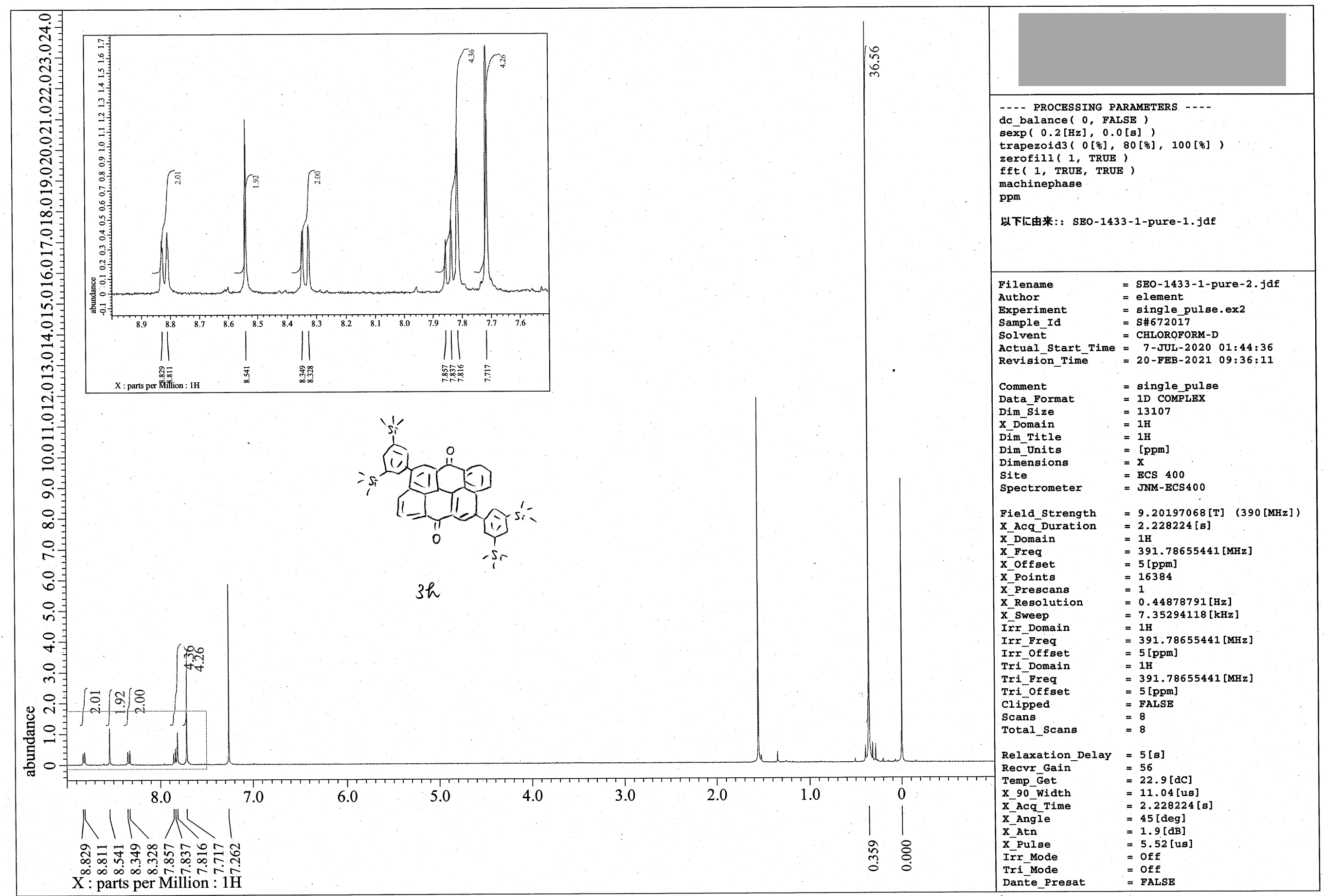




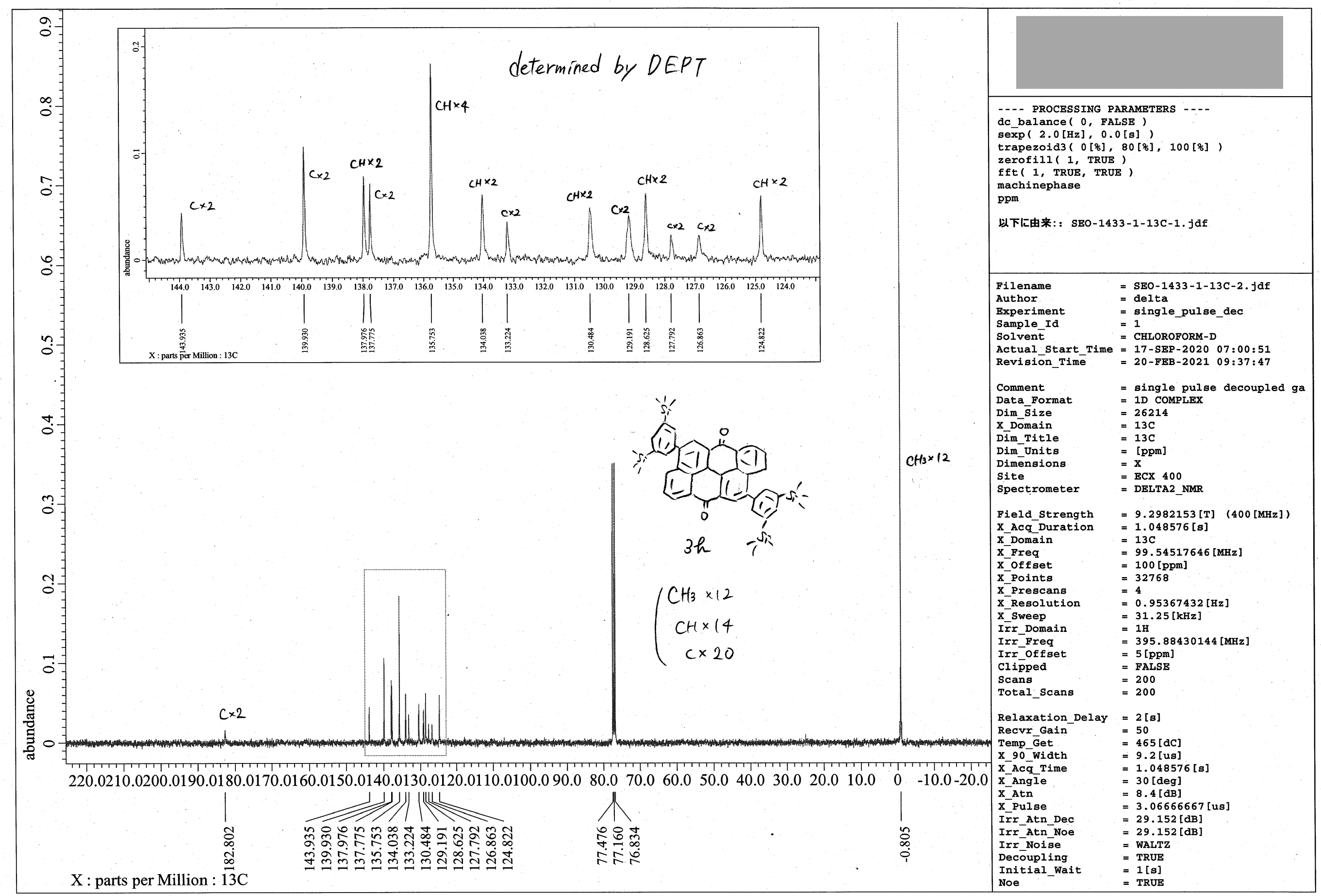




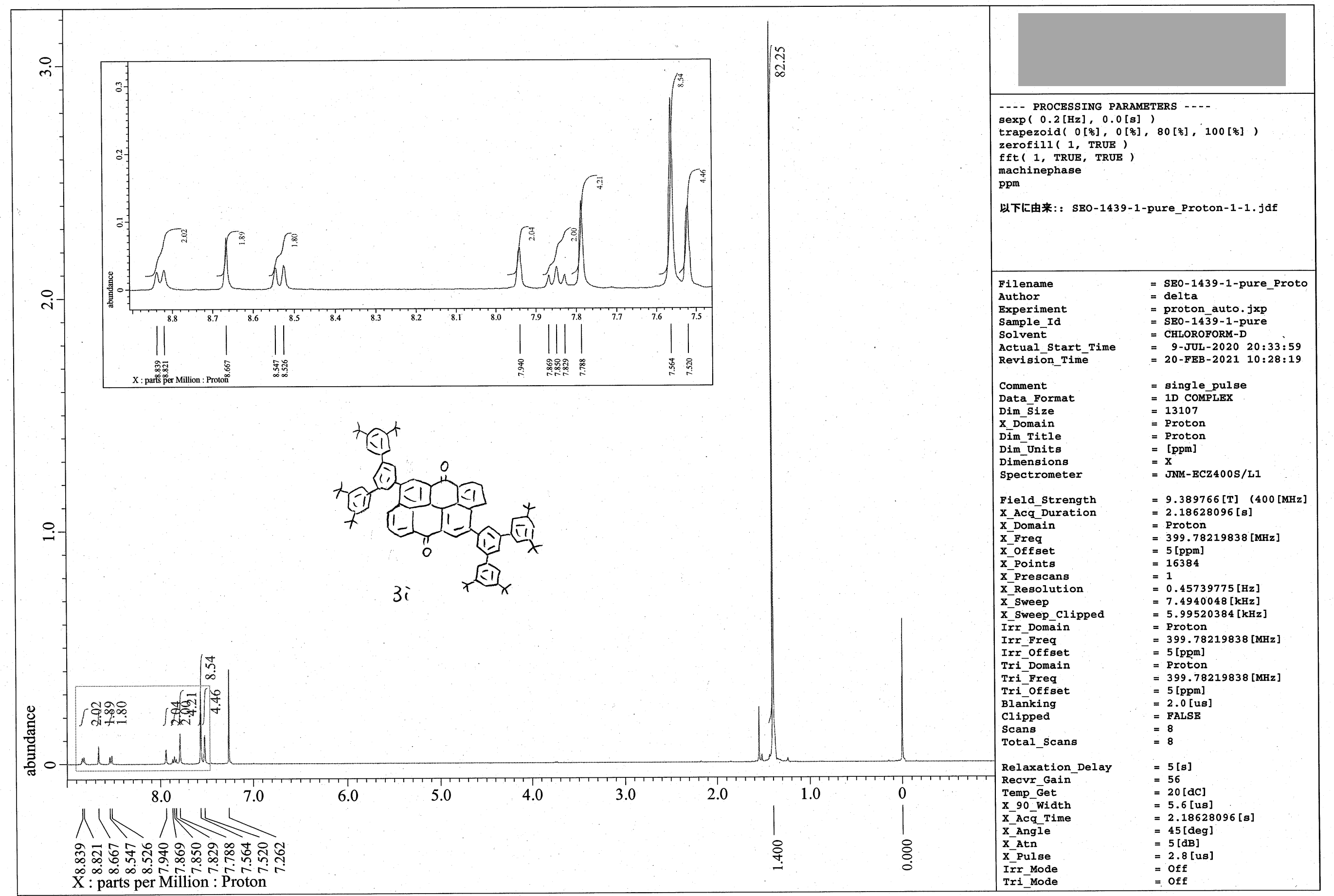




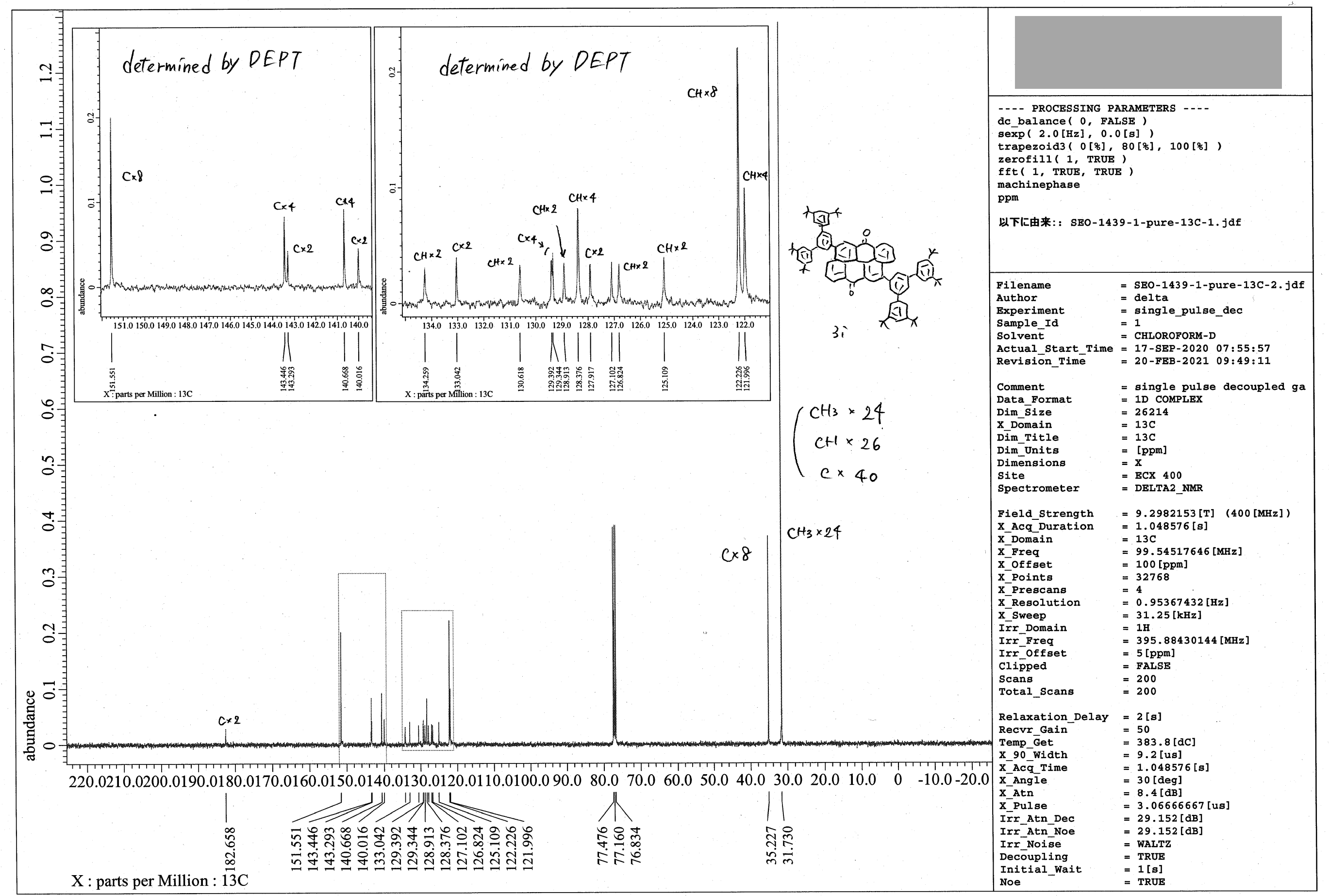




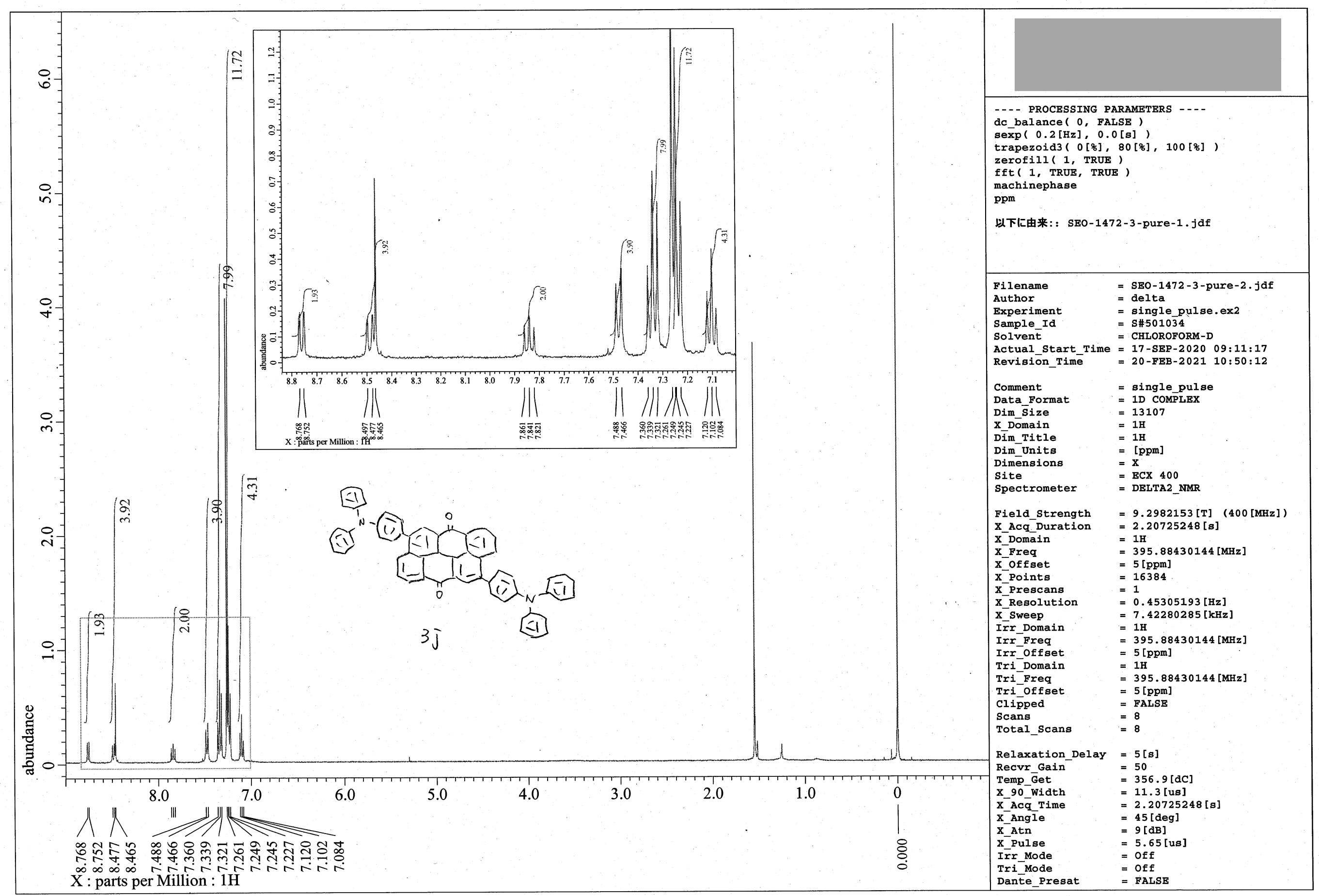




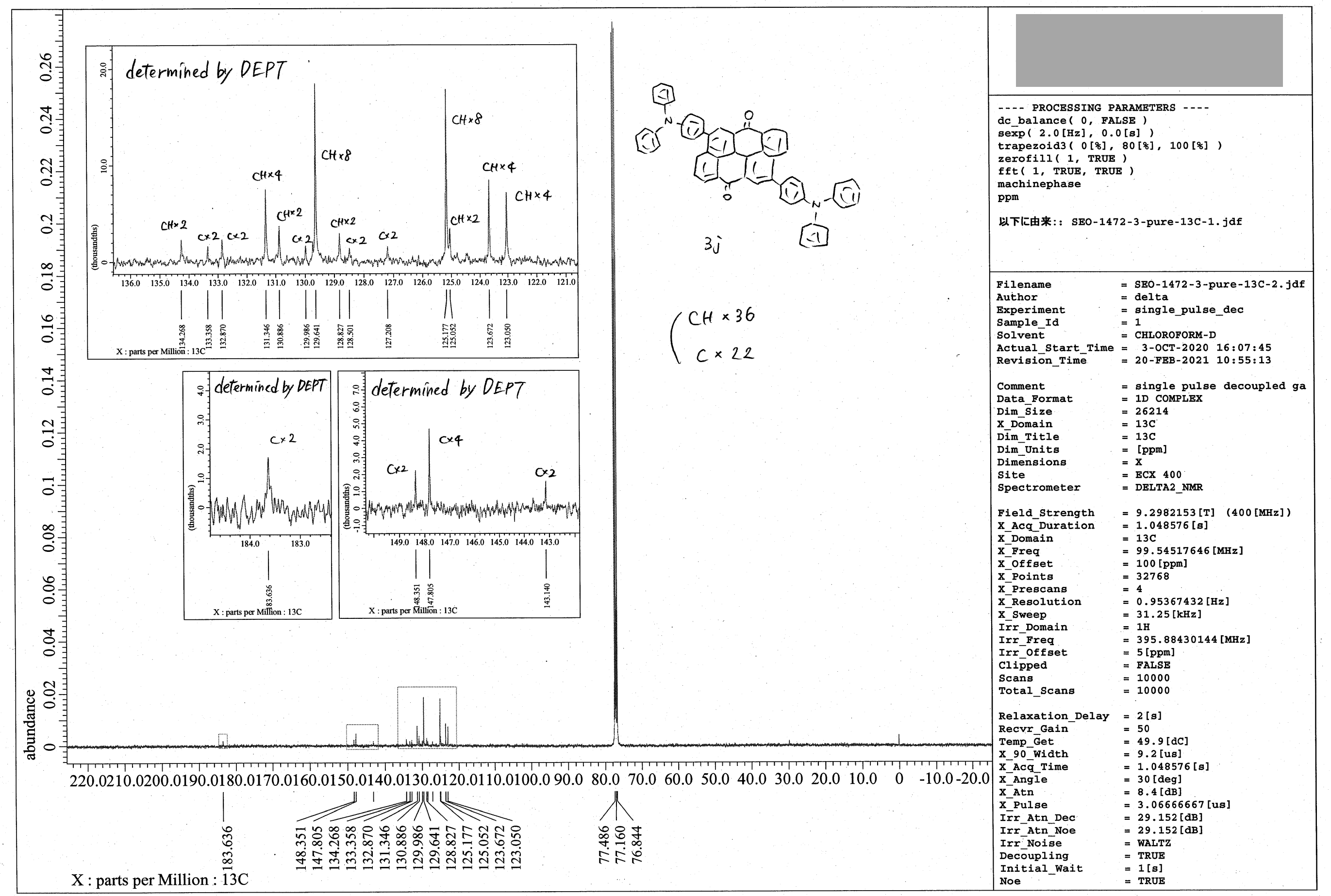




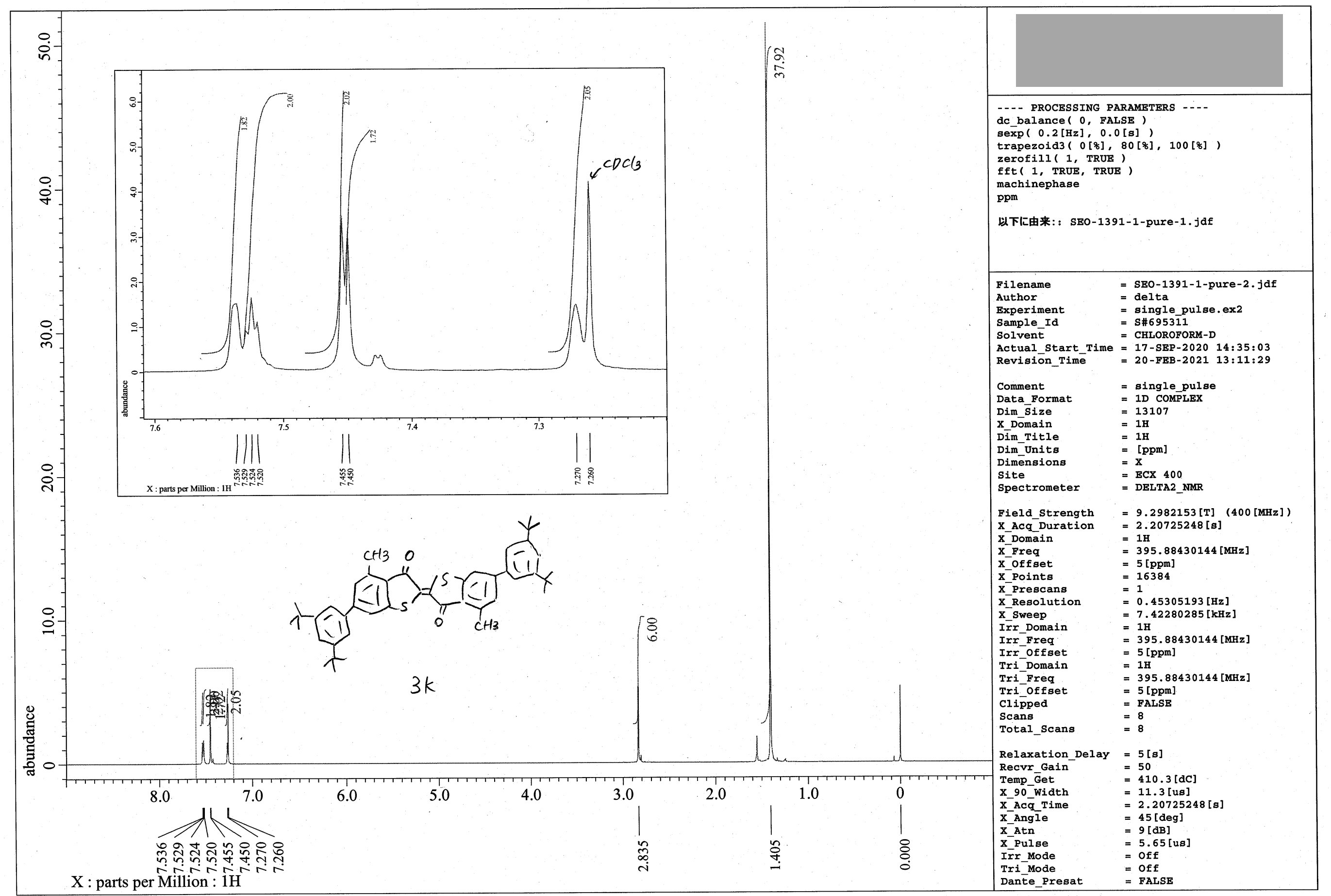




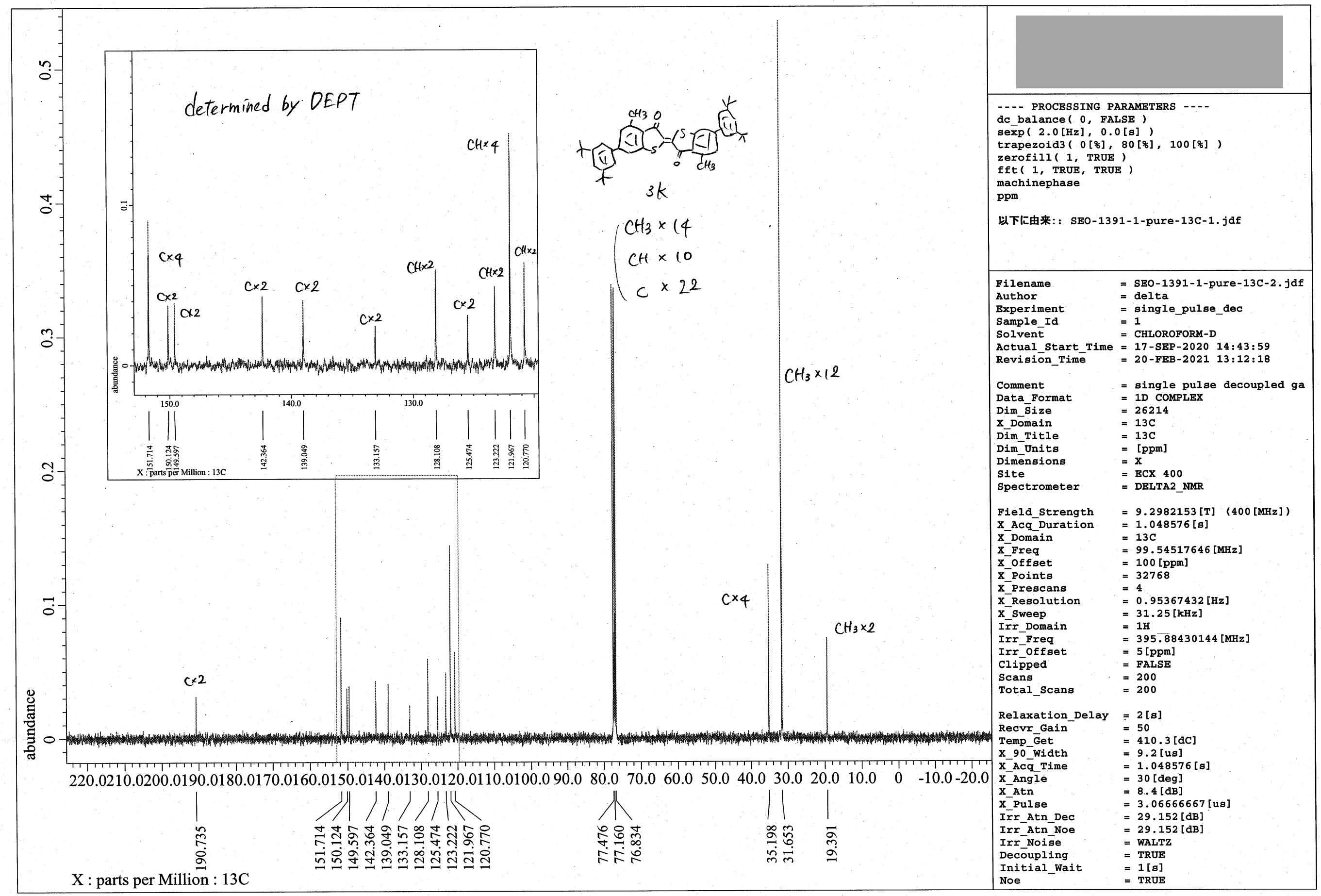




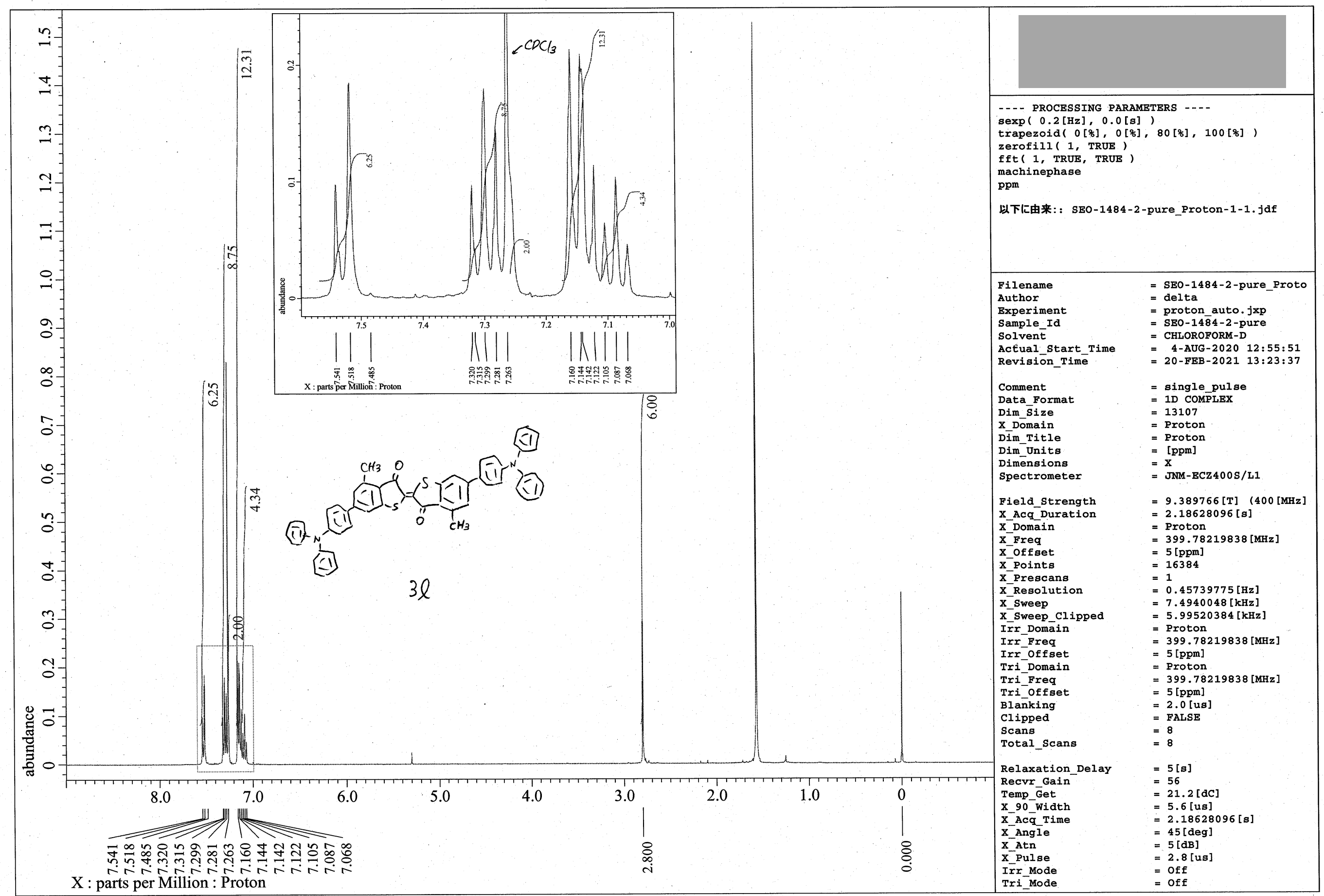




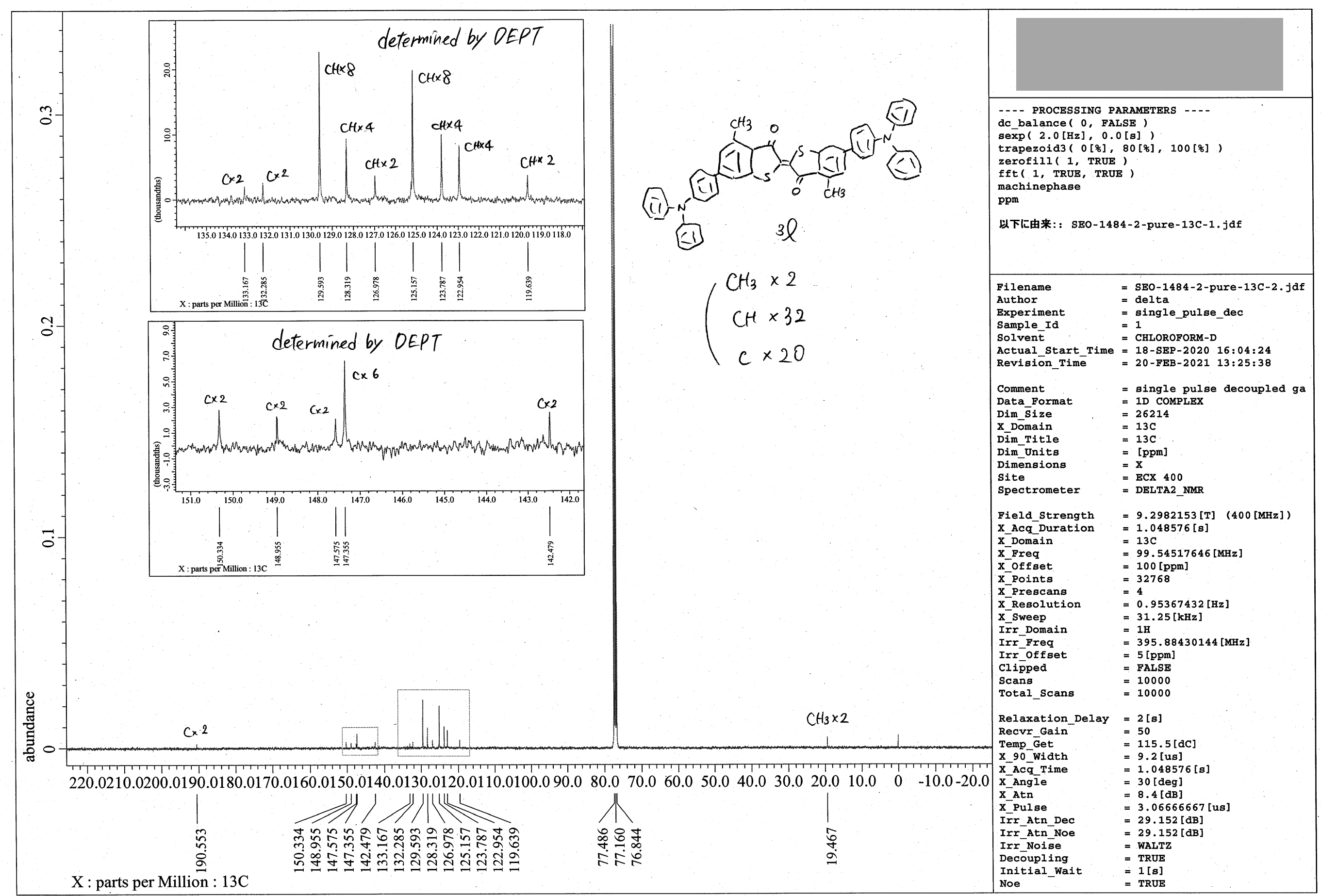




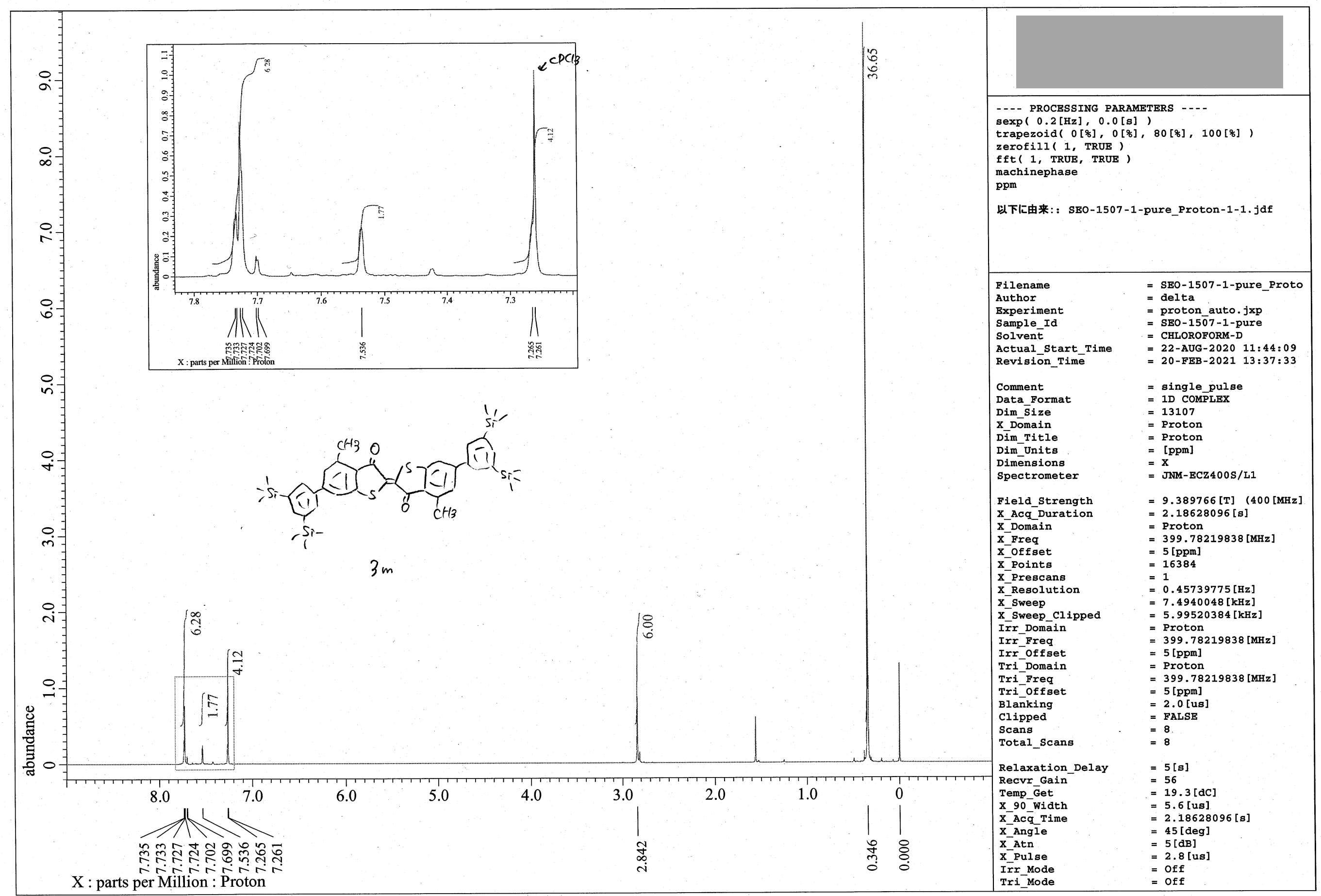




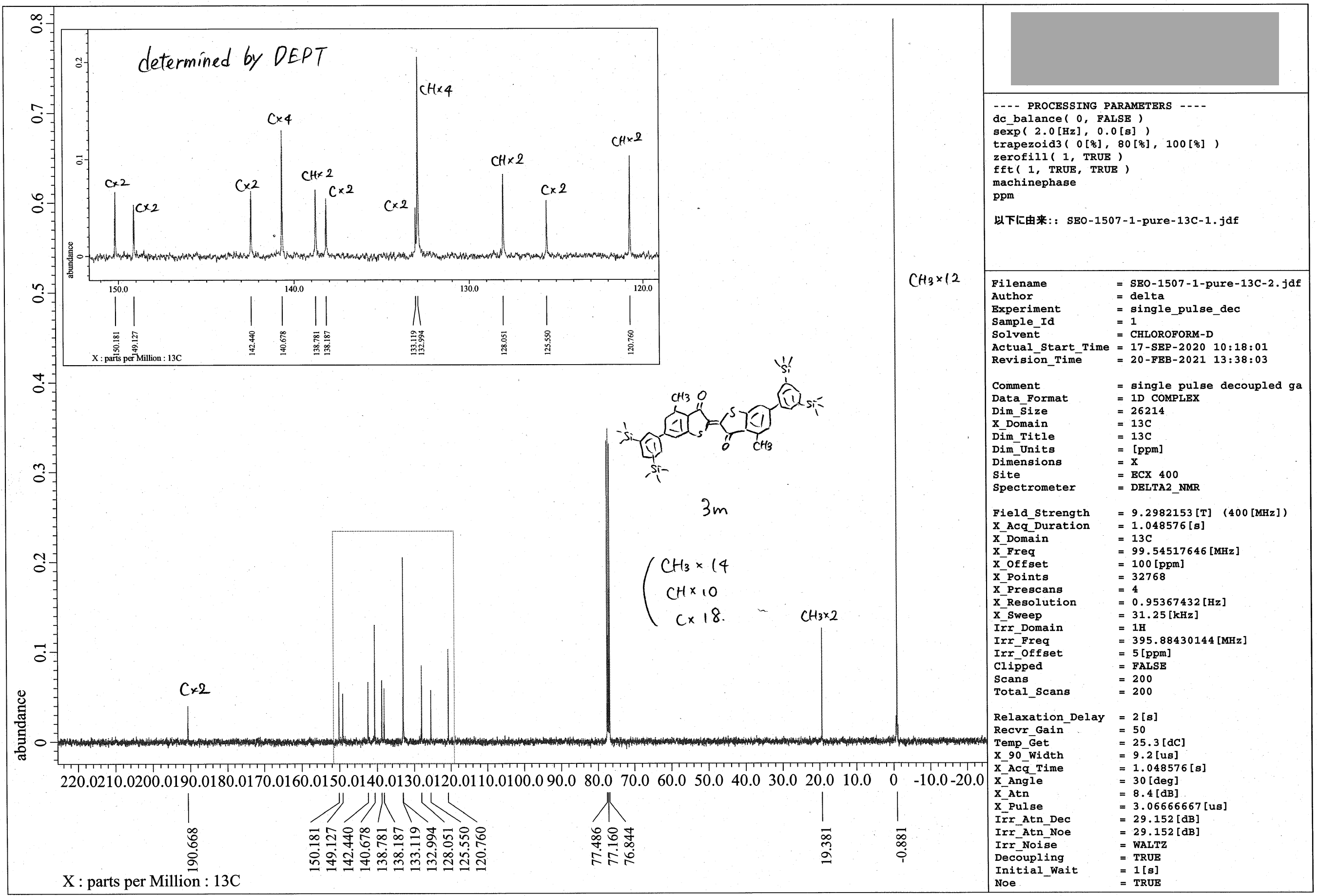




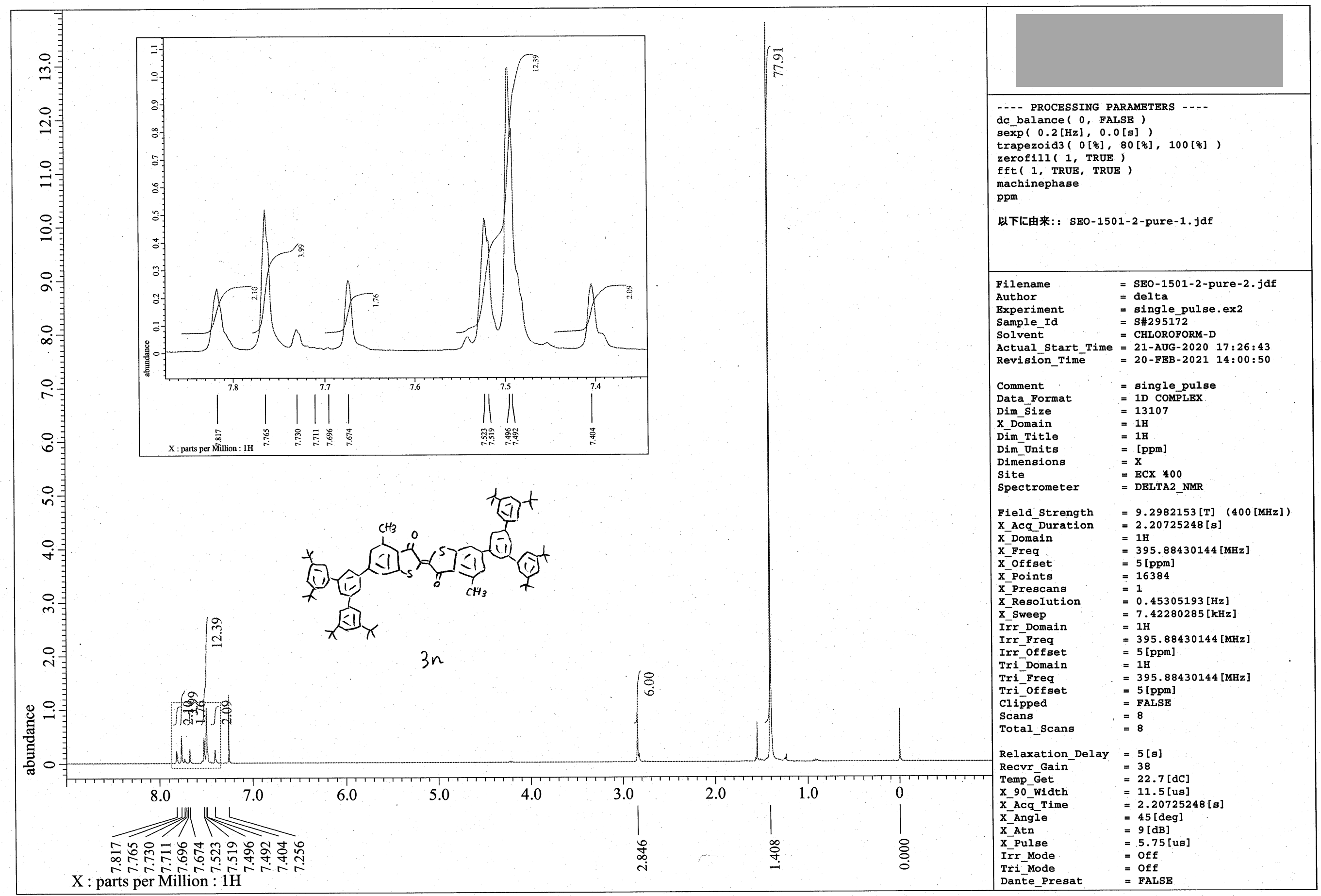




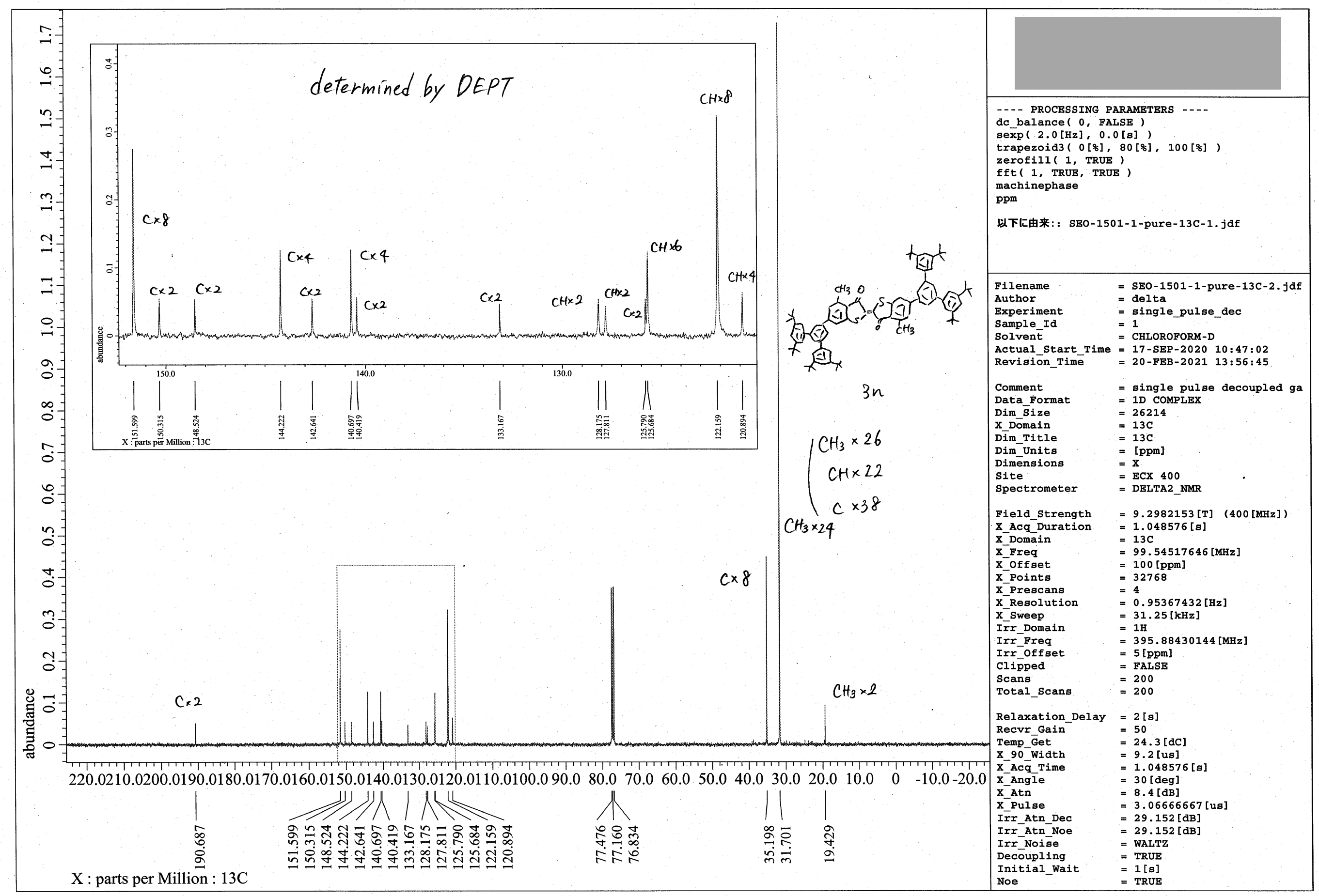




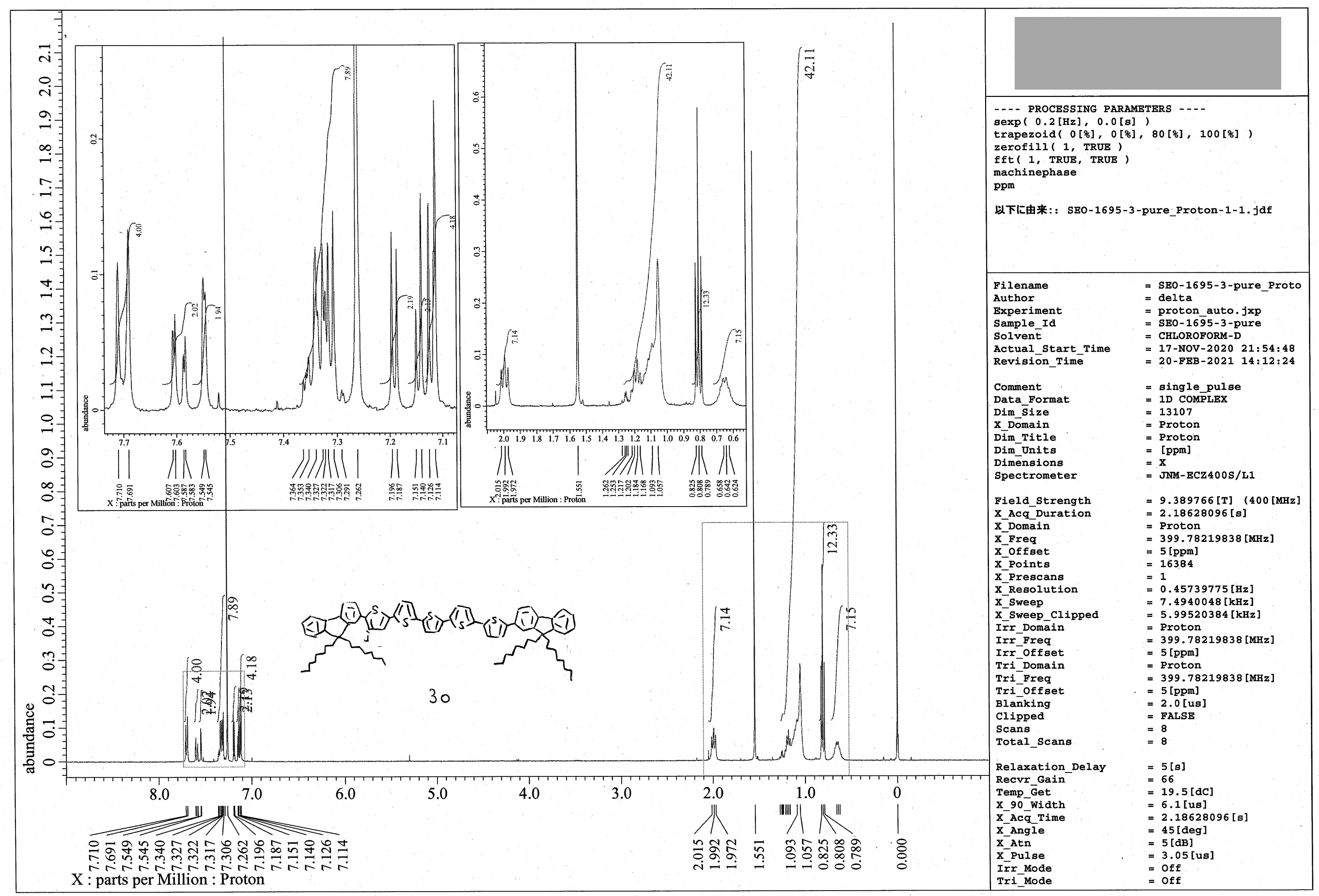




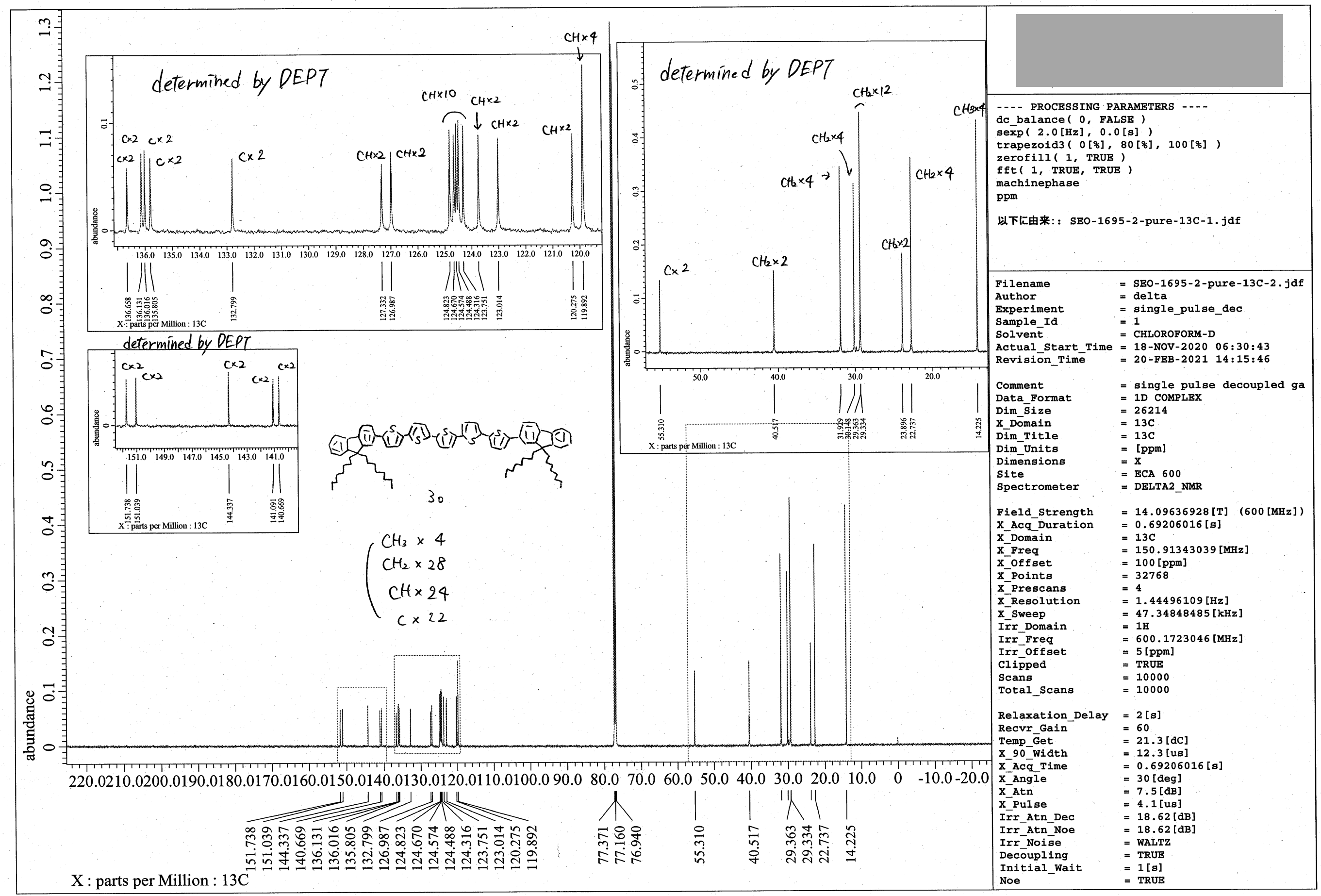




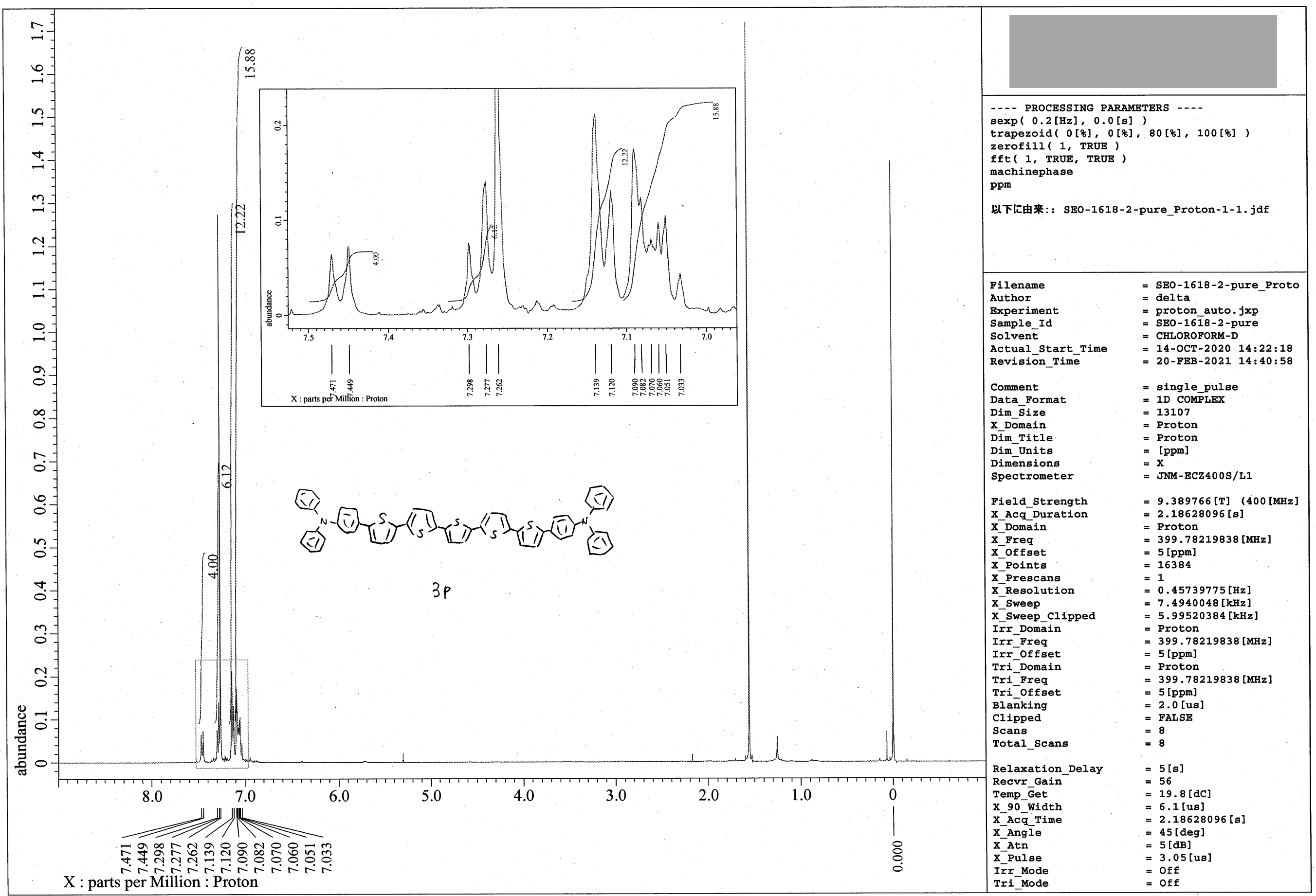




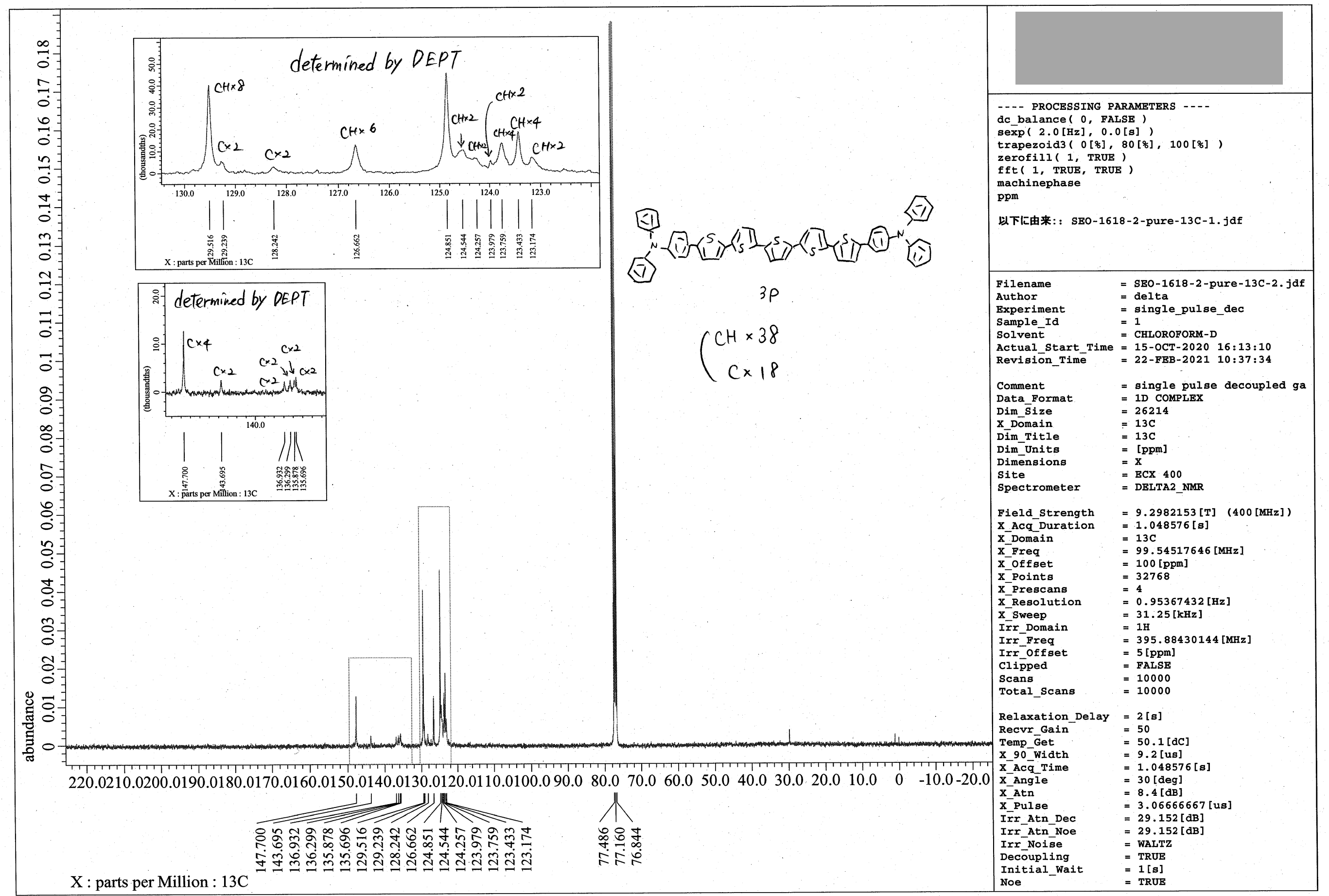




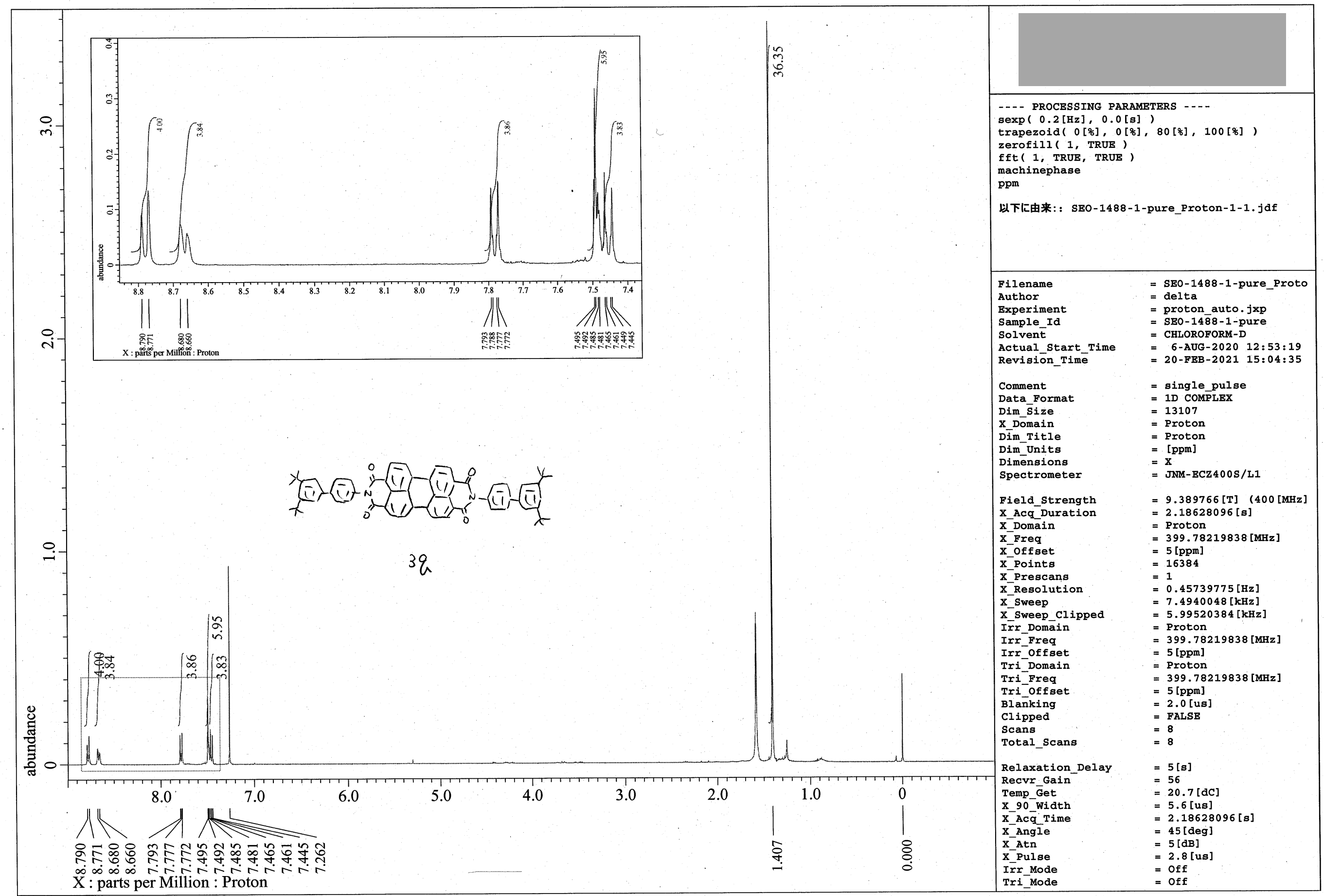




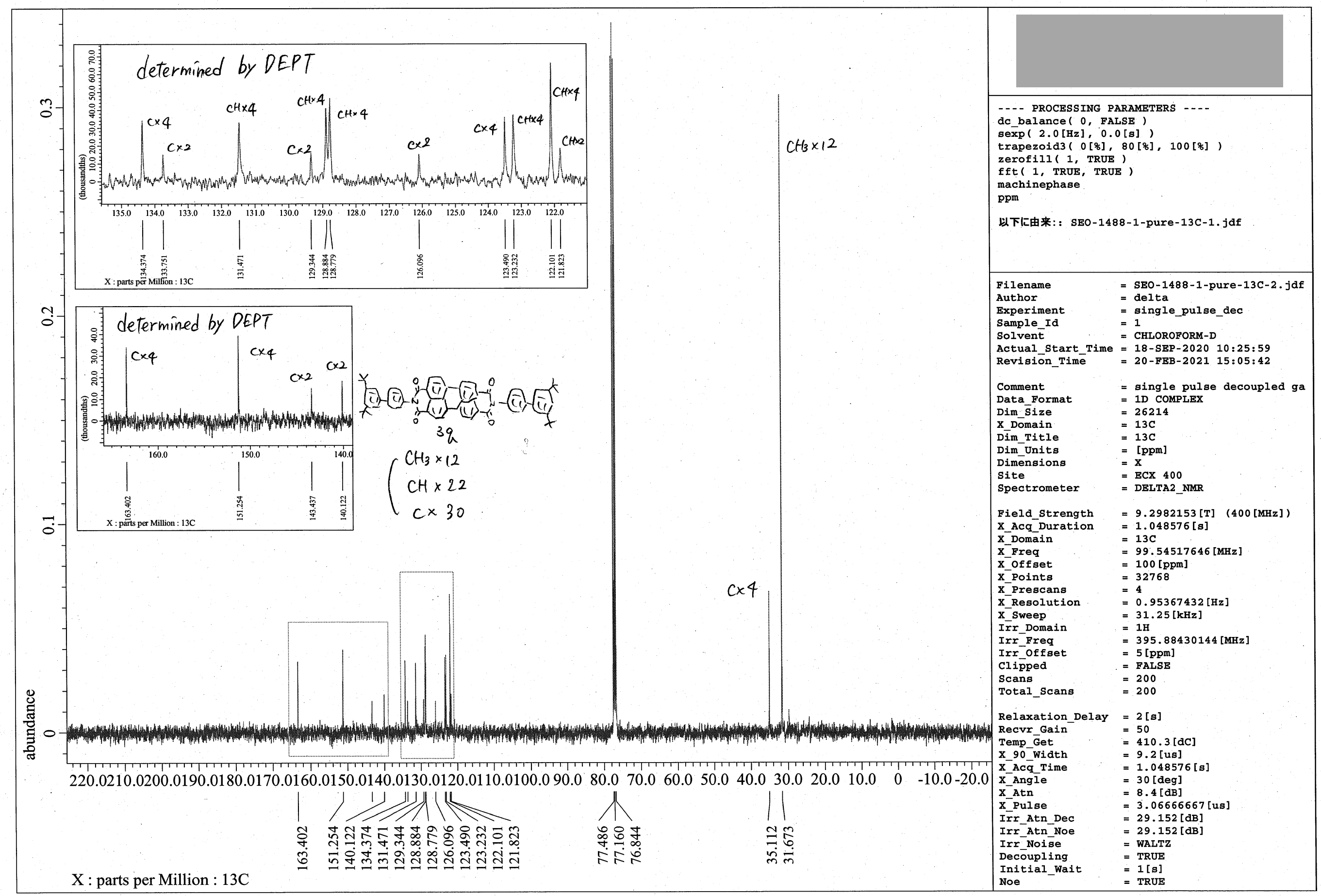




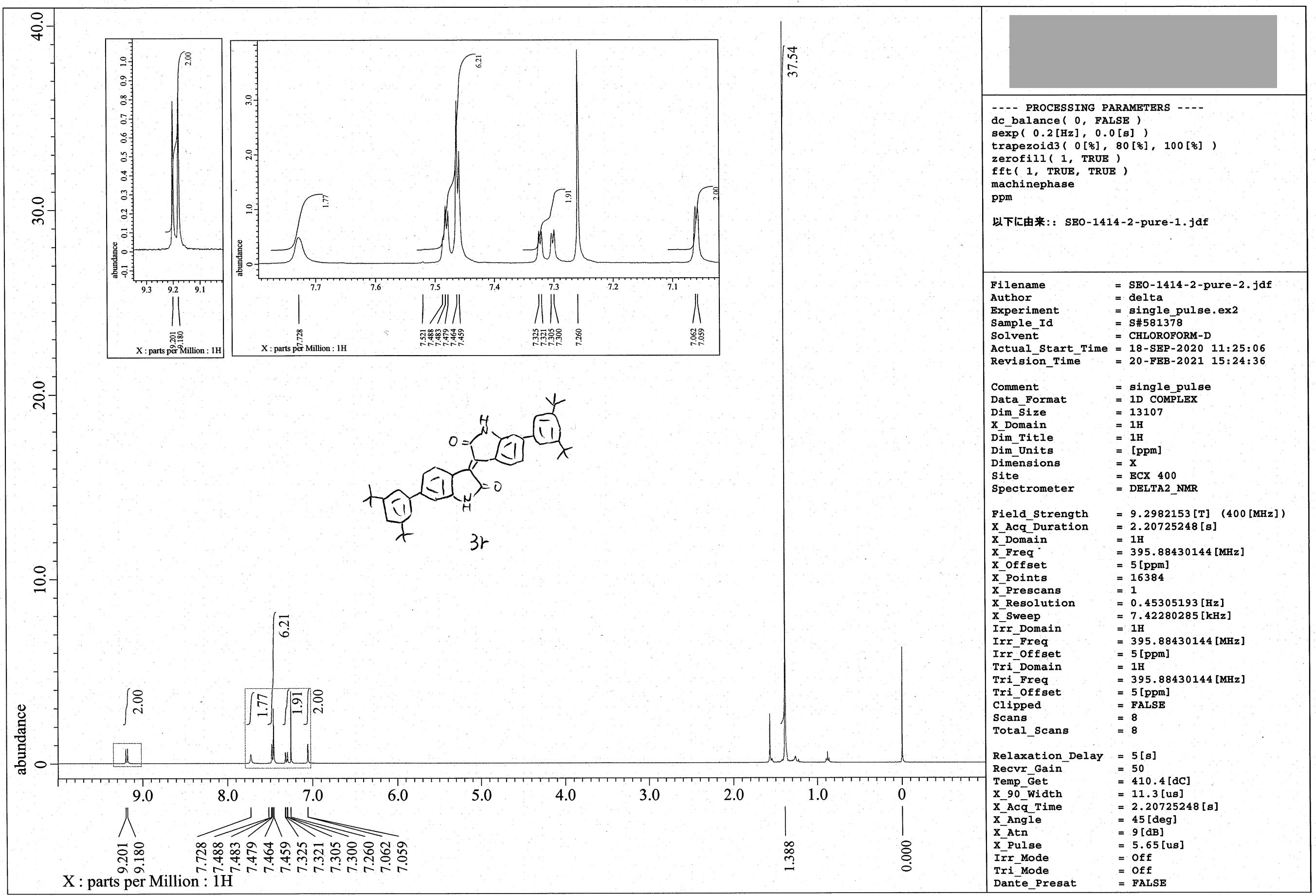




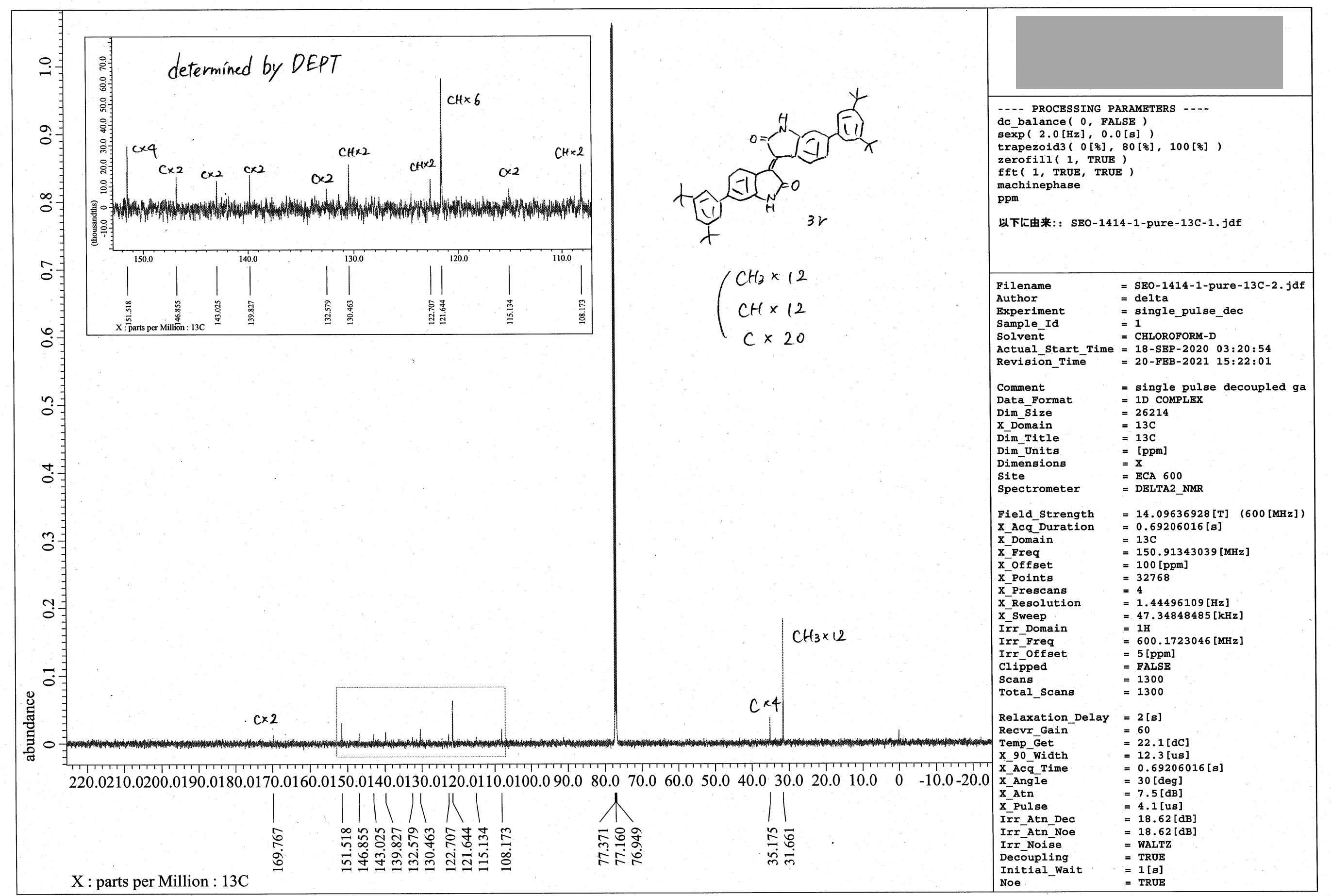




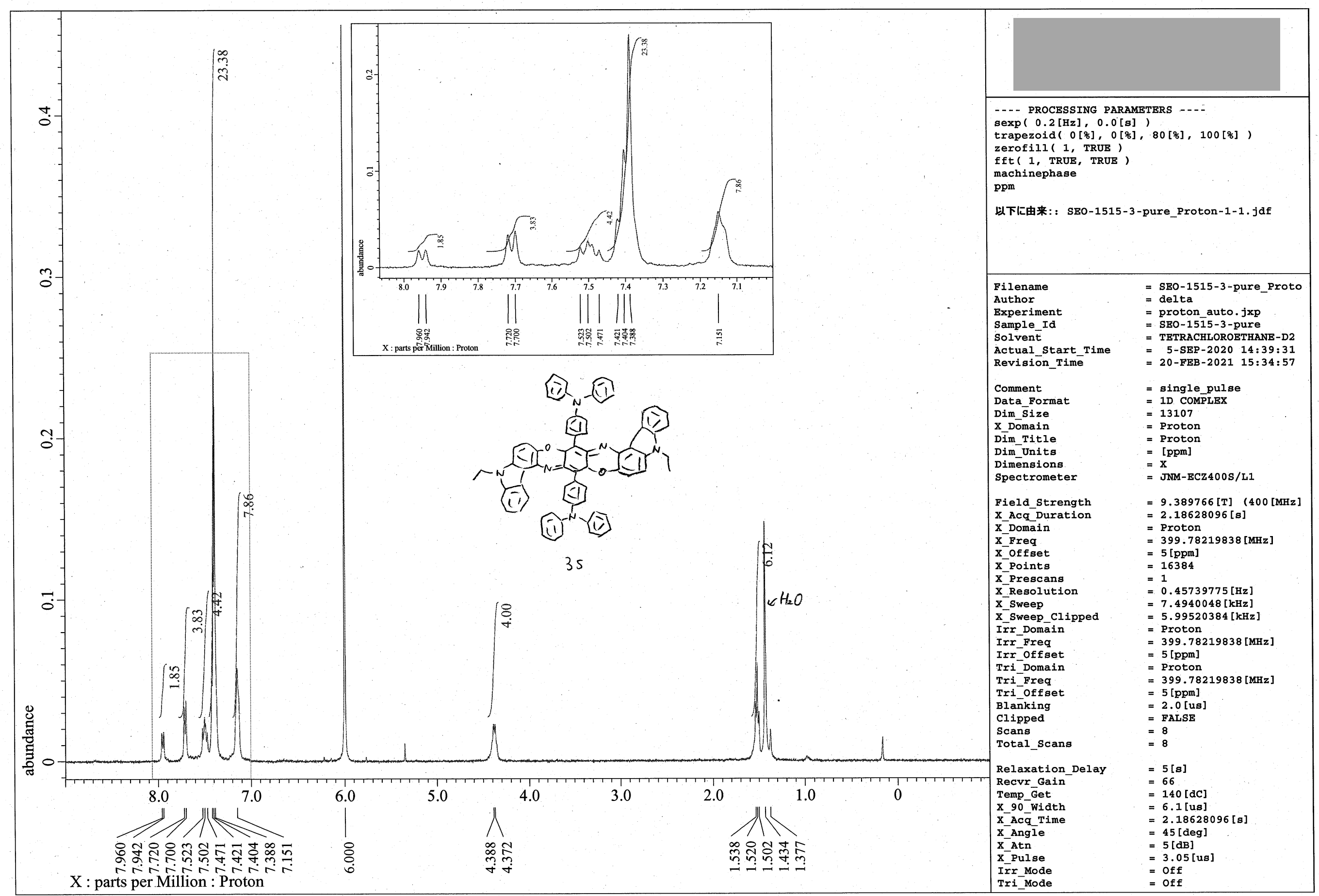




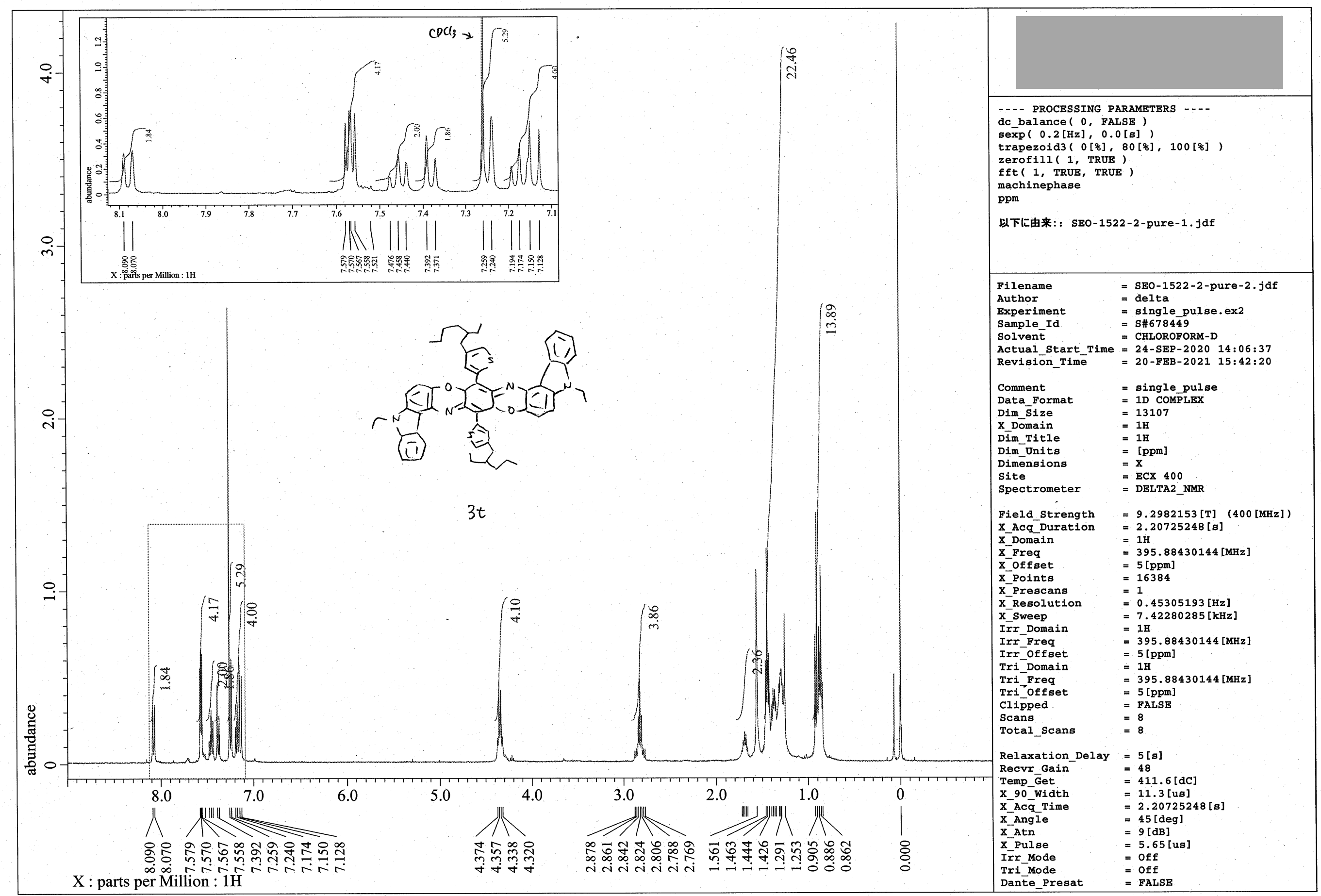




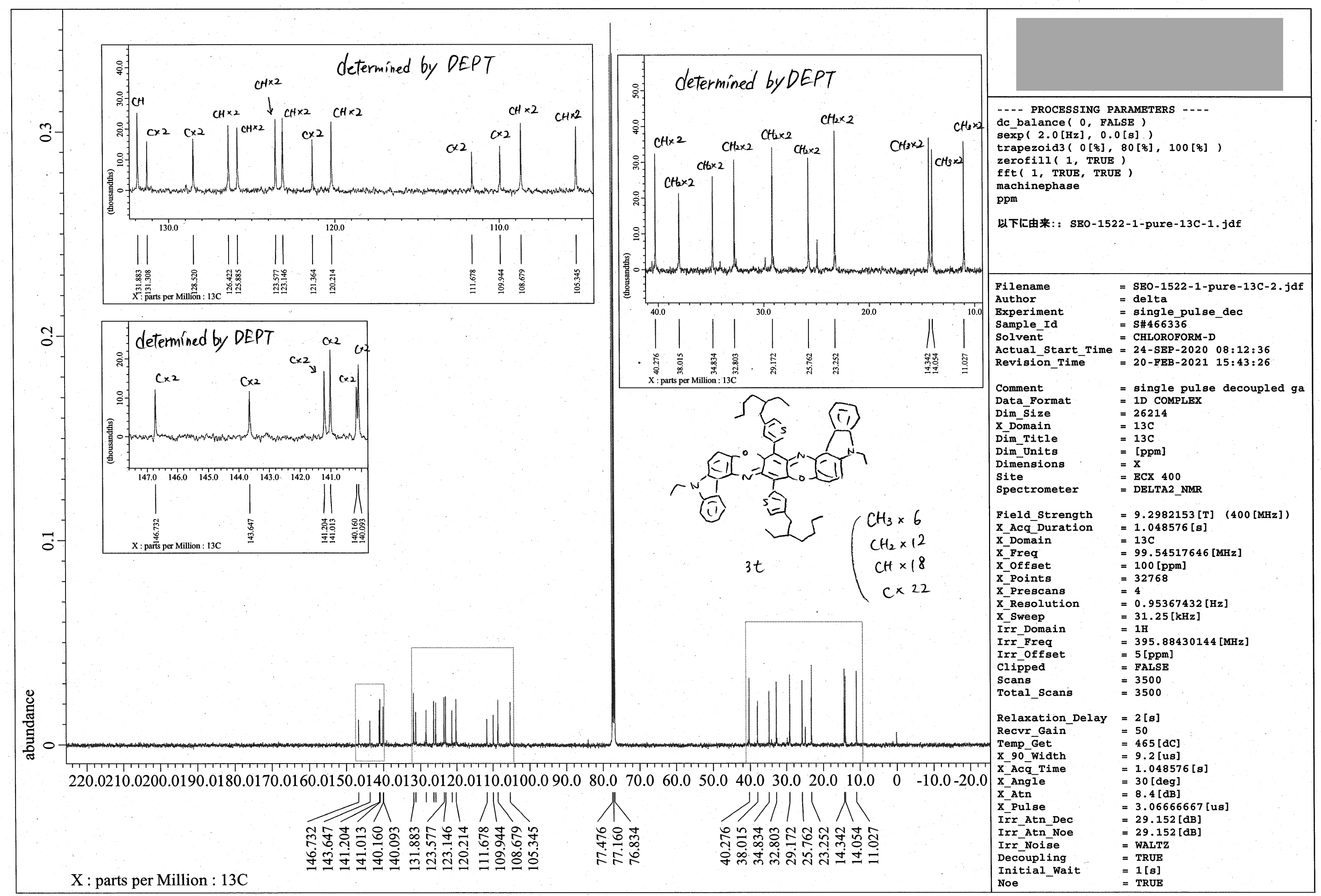




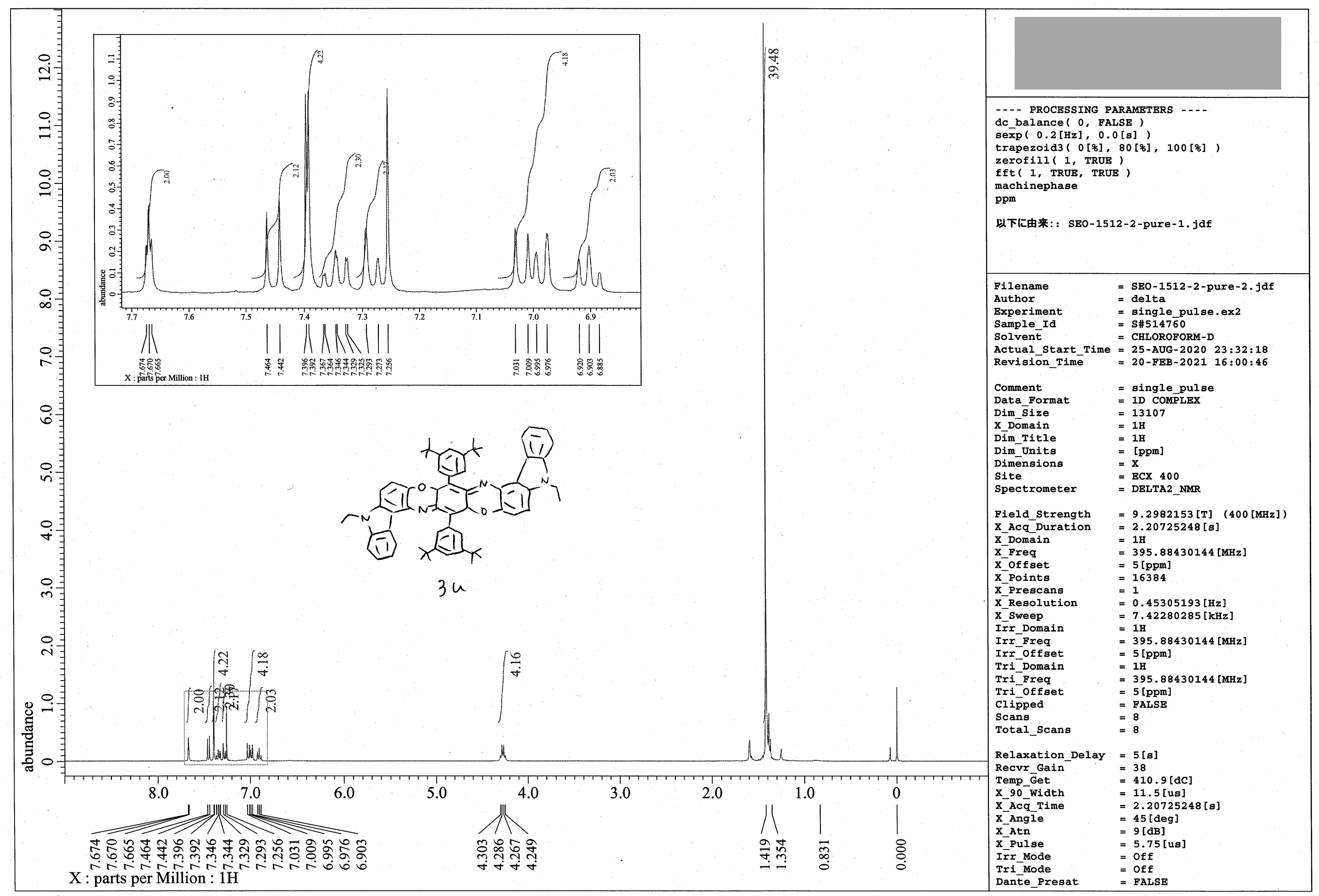




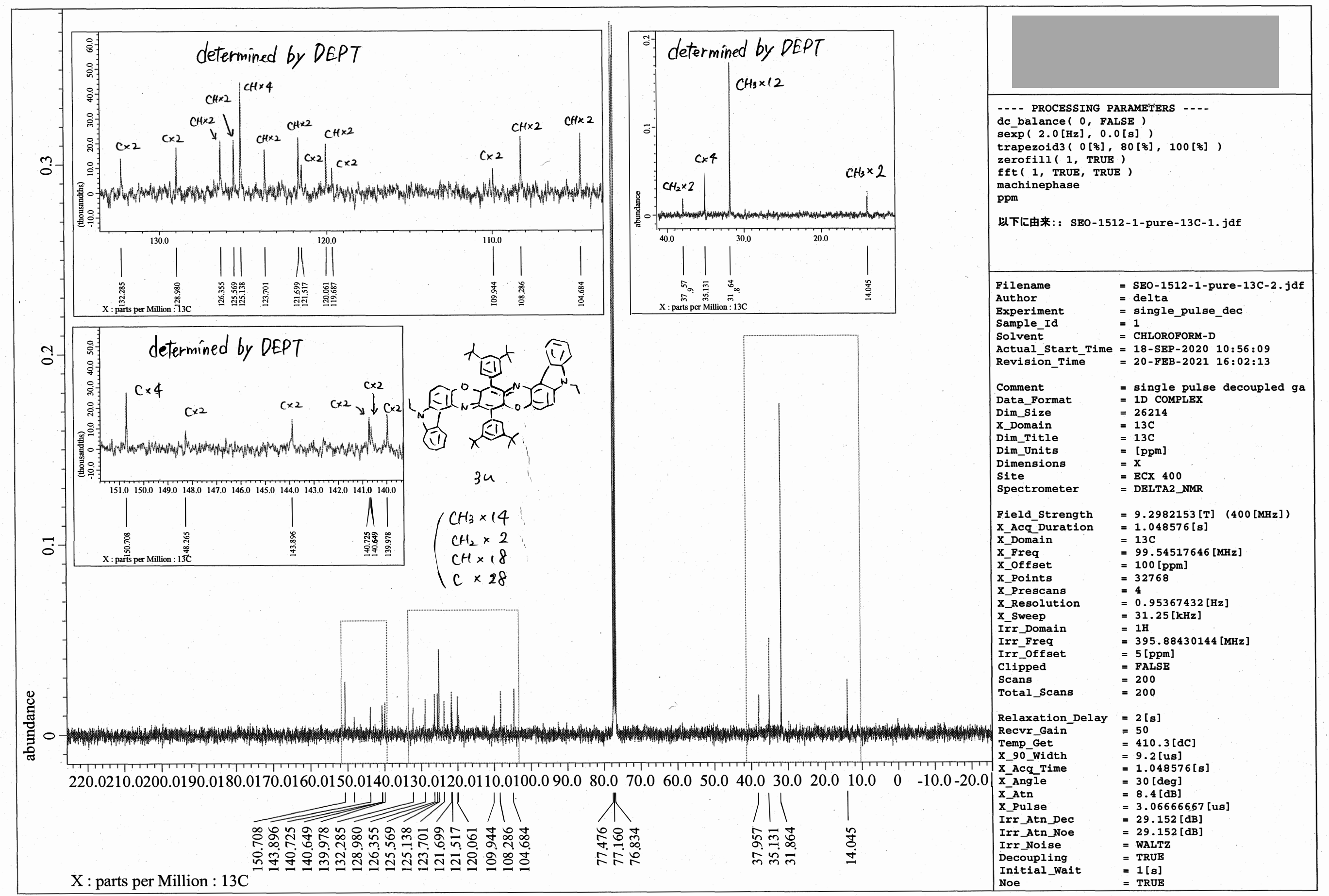

